Prepared in cooperation with the

New Hampshire Department of Environmental Services and in collaboration with the U.S. Environmental Protection Agency

\title{
Hydrogeologic Framework, Arsenic Distribution, and Groundwater Geochemistry of the Glacial- Sediment Aquifer at the Auburn Road Landfill Superfund Site, Londonderry, New Hampshire
}
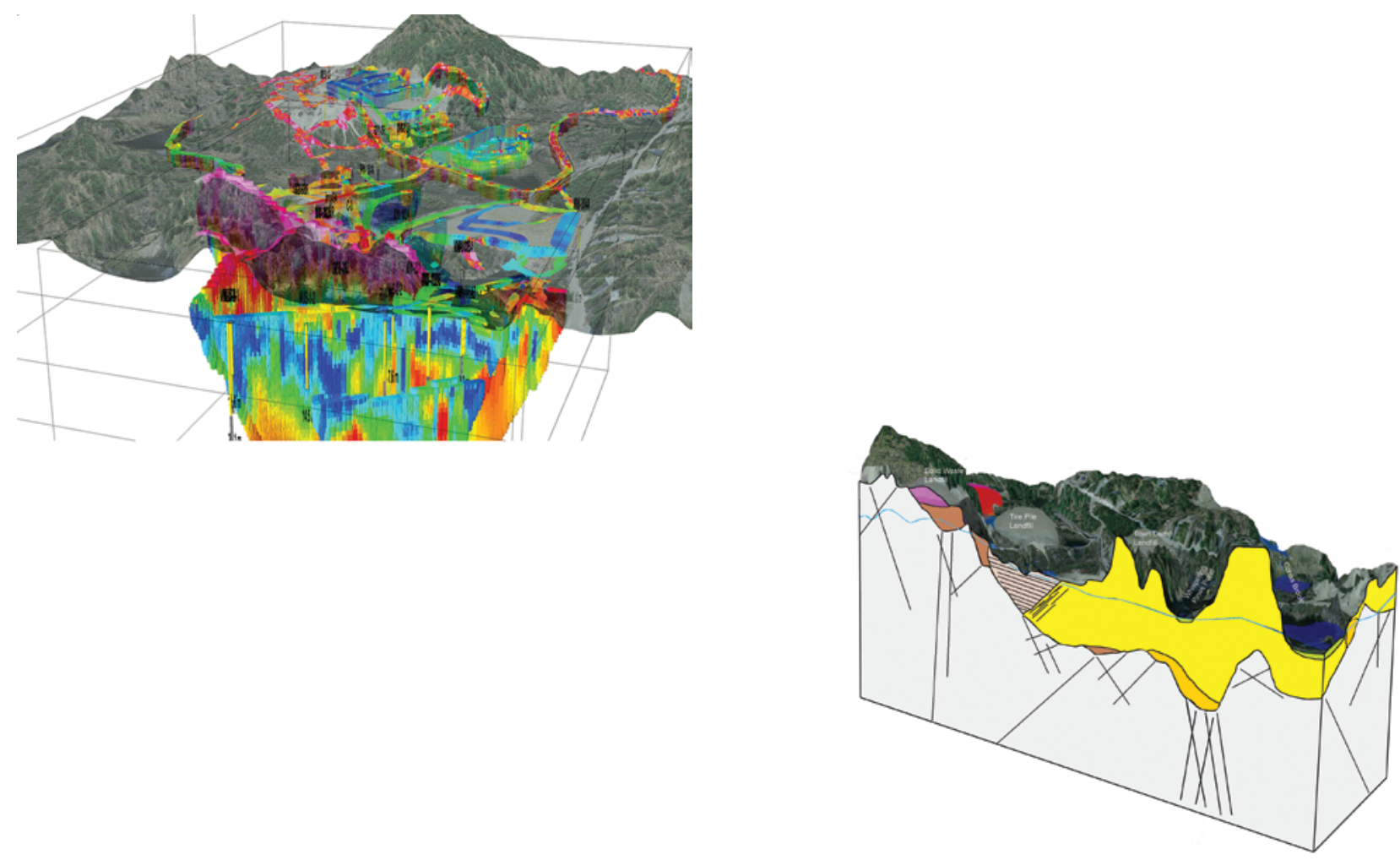

Scientific Investigations Report 2013-5123 
Front-cover art: Three-dimensional visualization of electrical geophysical results (upper left) with view toward the southeast, and conceptual model of hydrogeologic framework (lower right).

Back-cover art: Photographs of a direct-current resistivity survey at Whispering Pines Pond.

From left to right, Andrew Teeple, Byron Mah (1964-2012), and Roberto Cruz. 


\section{Hydrogeologic Framework, Arsenic Distribution, and Groundwater Geochemistry of the Glacial-Sediment Aquifer at the Auburn Road Landfill Superfund Site, Londonderry, New Hampshire}

By James R. Degnan and Philip T. Harte

Prepared in cooperation with the New Hampshire Department of Environmental Services and in collaboration with the U.S. Environmental Protection Agency

Scientific Investigations Report 2013-5123 


\title{
U.S. Department of the Interior SALLY JEWELL, Secretary
}

\section{U.S. Geological Survey Suzette M. Kimball, Acting Director}

\author{
U.S. Geological Survey, Reston, Virginia: 2013
}

For more information on the USGS - the Federal source for science about the Earth, its natural and living resources, natural hazards, and the environment, visit http://www.usgs.gov or call 1-888-ASK-USGS.

For an overview of USGS information products, including maps, imagery, and publications, visit http://www.usgs.gov/pubprod

To order this and other USGS information products, visit http://store.usgs.gov

Any use of trade, firm, or product names is for descriptive purposes only and does not imply endorsement by the U.S. Government.

Although this information product, for the most part, is in the public domain, it also may contain copyrighted materials as noted in the text. Permission to reproduce copyrighted items must be secured from the copyright owner.

Suggested citation:

Degnan, J.R., and Harte, P.T., 2013, Hydrogeologic framework, arsenic distribution, and groundwater geochemistry of the glacial-sediment aquifer at the Auburn Road landfill superfund site, Londonderry, New Hampshire: U.S. Geological Survey Scientific Investigations Report 2013-5123, 58 p., http://pubs.usgs.gov/sir/2013/5123/. 


\section{Acknowledgments}

Guidance during development of this project and background information from Byron Mah, (1964-2012) of the U.S. Environmental Protection Agency (USEPA), was essential for project planning and progress. He visited the field site to help with reconnaissance and to oversee geophysical surveys. Byron's dedication to the site was shown through his questions, site visits, relationships with land owners, facilitation of site reuse, and enthusiasm for project meetings. He brought people together to develop a more thorough understanding of the processes at work at the site to produce a clean and fair outcome. Jean Choi, also of the USEPA, provided information and assisted with geophysical surveys and piezometer-installation field work at the site. Constructive reviews from Marcel Belaval, Mike Jazinski, Daryl Luce, and Richard Hull of the USEPA were helpful in creating a more relevant and useful product. Sean Combs and Andrew Fuller from Weston Solutions provided data that helped with this study. Permission and logistical support from landowners who allowed access to their land, made data collection possible. The authors would like to thank all who have assisted with and supported this project. Site reconnaissance and project-planning help from Tom Andrews and Kenneth Richards, New Hampshire Department of Environmental Services, helped to keep the study moving forward. Help with water-quality and geophysical data collection and formatting by volunteer Blaine Ayotte is appreciated.

Site reconnaissance and project-planning help were provided by Joe Ayotte and Tom Mack of the U.S. Geological Survey (USGS). Kelsey Ann Regan of the USGS helped in the field and with data mining. Field-data collection was possible with assistance from Roberto Cruz, Jason Sorenson, and Kelly McMahon of the USGS. Equipment, help in the field, and technical advice provided by Andrew Teeple, Alton Anderson, and Eric White of the USGS made high-quality data collection possible. Jason Payne of the USGS helped with electromagnetic-data processing. Critical report reviews by Richard Moore, Charles Walker, and Andrew Teeple of the USGS are greatly appreciated. 
THIS PAGE INTENTIONALLY LEFT BLANK 


\section{Contents}

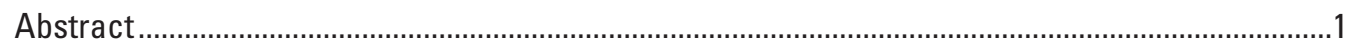

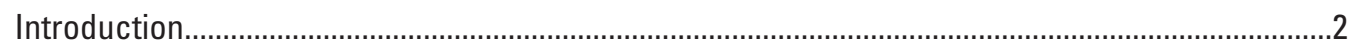

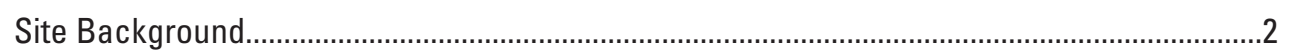

Hydrogeologic Setting .................................................................................................

Arsenic in Groundwater and Contaminants at Landfills ........................................................

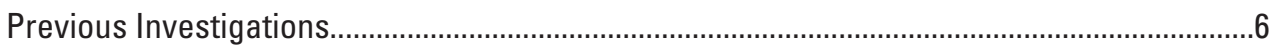

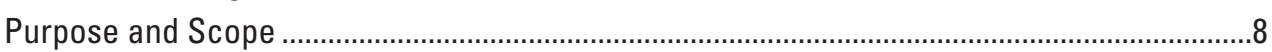

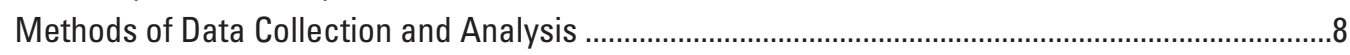

Geophysics and Hydrogeologic Framework ......................................................................

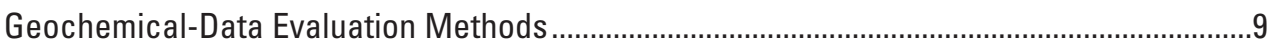

Hydrogeologic Framework and Groundwater Geochemistry ........................................................10

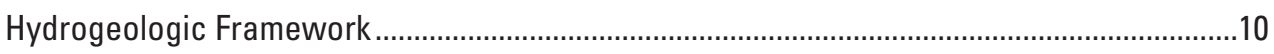

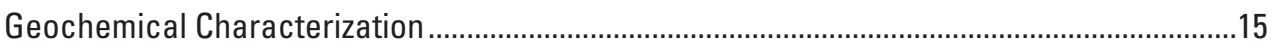

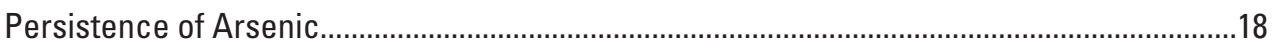

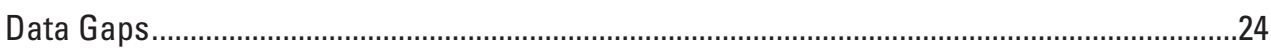

Aquifer and Landfill-Matrix Solids ...............................................................................24

Indicators of Leachate and Groundwater Redox .......................................................24

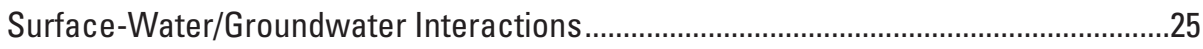

Hydrogeologic Framework of the Bedrock Aquifer .....................................................25

Hydrogeologic Framework of the Glacial-Sediment Aquifer ..........................................25

Groundwater Flow and Three-Dimensional Geochemical Model..................................26

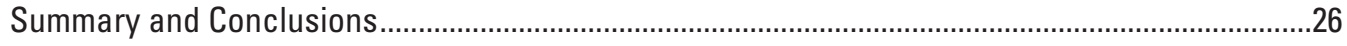

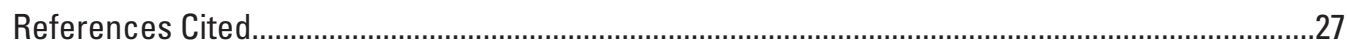

Appendix 1. Summary of Results of Geophysical-Data Processing and Borehole

Geophysical Log Analysis ...........................................................................................35

Appendix 2. Three-Dimensional Diagram Showing Locations of Wells, Bedrock-Surface

Altitudes from Seismic Refraction Surveys, and Results from Electromagnetic and

Direct-Current Resistivity Geophysical Surveys ...................................................................41

Appendix 3. Preliminary Bedrock-Surface Map ....................................................................43

Appendix 4. Geochemical Data Used for Redox-Zone Classification, Spring 2008_.......................45

Appendix 5. Preliminary Spatial Distribution of Redox Zones, Water Table, and Flow Directions in the Glacial-Sediment Aquifer, Spring 2008..............................................47

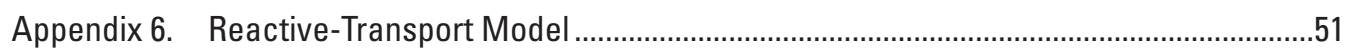

Appendix 7. Piezometer Installation and Results of Analysis of Groundwater Samples, 2012 ...55

\section{Figures}

1. Map showing the location of surface features, wells, and geophysical-survey lines discussed in this report, Auburn Road Landfill Superfund Site, Londonderry,

New Hampshire

2. Diagram showing the conceptual model of the hydrogeology and groundwater flow at the Auburn Road Landfill Superfund Site, Londonderry, New Hampshire 
3. Diagram showing $A$, aerial view of the location of line 10 of the direct-current resistivity survey and wells that are projected on the cross section and $B$, cross section showing direct-current resistivity results, July 2011, the altitude of the bedrock surface interpreted from these results, and lithologic logs in wells along line 10 in the former gravel pit, Auburn Road Landfill Superfund Site, Londonderry, New Hampshire .....

4. Diagram showing $A$, aerial view of the location of line 12 of the direct-current resistivity survey and wells that are projected on the cross section and $B$, cross section showing direct-current resistivity results, July 2011, the altitude of the bedrock surface interpreted from these results, and lithologic logs in wells along line 12, Auburn Road Landfill Superfund Site, Londonderry, New Hampshire.

5. Diagram showing $A$, aerial view of the location of line 2 of the direct-current resistivity survey and wells that are projected on the cross section and $B$, cross section showing direct-current resistivity results, February 2011, the altitude of the bedrock surface interpreted from these results, and lithologic logs in wells along line 2 beneath Whispering Pines Pond, Auburn Road Landfill Superfund Site, Londonderry, New Hampshire.

6. Graphs showing the specific conductance of groundwater as a function of the concentrations of five constituents in water from wells in bedrock and overburden, spring 2008, Auburn Road Landfill Superfund Site, Londonderry, New Hampshire ........16

7. Graphs showing the concentration of arsenic as a function of landfill-leachate indicators in water from wells in bedrock and overburden, spring 2008, Auburn Road Landfill Superfund Site, Londonderry, New Hampshire.

8. Graphs showing the concentration of arsenic as a function of redox indicators in water from wells in bedrock and overburden, spring 2008, Auburn Road Landfill Superfund Site, Londonderry, New Hampshire.

9. Diagram showing $A$, aerial view of the location of the cross section and wells that are projected on the cross section and $B$, cross section showing redox conditions and concentrations of arsenic in groundwater along a flow path from the solid-waste landfill to Whispering Pines Pond, spring 2008, Auburn Road Landfill Superfund Site, Londonderry, New Hampshire.

10. Diagram showing $A$, aerial view of the location of the cross section and wells that are projected on the cross section and $B$, cross section showing redox conditions and concentrations of arsenic in groundwater along a flow path from the towndump landfill to Cohas Brook, spring 2008, Auburn Road Landfill Superfund Site, Londonderry, New Hampshire.

11. Graphs showing concentrations of arsenic in groundwater by year and well $A$, between landfills, $B$, in the gravel pit, and $C$, beneath Whispering Pines Pond, Auburn Road Landfill Superfund Site, Londonderry, New Hampshire

12. Bar graphs showing results of sensitivity analyses of the $A$, relative effect of parameter adjustment on the dimensionless arsenic concentration, and $B$, the percent difference between the simulated times to achieve the standard for dissolved arsenic at Whispering Pines Pond, Auburn Road Landfill Superfund Site, Londonderry, New Hampshire.

\section{Table}

1. Hydrogeologic and groundwater-quality data from previous studies, Auburn Road Landfill Superfund Site, Londonderry, New Hampshire 


\section{Conversion Factors, Datum, and Abbreviations}

Inch/Pound to SI

\begin{tabular}{lll}
\hline \multicolumn{1}{c}{ Multiply } & By & \multicolumn{1}{c}{ To obtain } \\
\hline foot $(\mathrm{ft})$ & Length & \\
mile (mi) & 0.3048 & meter $(\mathrm{m})$ \\
\hline & 1.609 & kilometer $(\mathrm{km})$ \\
\hline acre & Area & \\
\hline & 0.004047 & square kilometer $\left(\mathrm{km}^{2}\right)$ \\
\hline foot per day $(\mathrm{ft} / \mathrm{d})$ & Flow rate & \\
\hline & 0.3048 & meter per day $(\mathrm{m} / \mathrm{d})$ \\
\hline foot squared per day $\left(\mathrm{ft}^{2} / \mathrm{d}\right)$ & Transmissivity & \\
\hline
\end{tabular}

Vertical coordinate information is referenced to the National Geodetic Vertical Datum of 1929 (NGVD of 1929).

Horizontal coordinate information is referenced to the North American Datum of 1983 (NAD 83).

Altitude, as used in this report, refers to distance above the vertical datum.

Specific conductance is given in microsiemens per centimeter at 25 degrees Celsius $(\mu \mathrm{S} / \mathrm{cm}$ at $\left.25^{\circ} \mathrm{C}\right)$.

Concentrations of chemical constituents in water are given either in milligrams per liter ( $\mathrm{mg} / \mathrm{L})$ or micrograms per liter ( $\mu \mathrm{g} / \mathrm{L})$.

Electrical resistivity is measured in ohm meters.

\section{Abbreviations}

$\begin{array}{ll}\text { DC } & \text { direct current } \\ \text { DO } & \text { dissolved oxygen } \\ \text { EM } & \text { electromagnetic-induction } \\ \text { FDEM } & \text { frequency-domain electromagnetic } \\ \text { GIS } & \text { geographic information system } \\ \text { GPR } & \text { ground-penetrating radar } \\ \text { GPS } & \text { global positioning system } \\ \text { MCL } & \text { maximum contaminant level } \\ \text { NHDES } & \text { New Hampshire Department of Environmental Services } \\ \text { ROD } & \text { record of decision } \\ \text { SC } & \text { specific conductance } \\ \text { TOC } & \text { total organic carbon } \\ \text { USEPA } & \text { U.S. Environmental Protection Agency } \\ \text { USGS } & \text { U.S. Geological Survey } \\ \text { VOC } & \text { volatile organic compound }\end{array}$


THIS PAGE INTENTIONALLY LEFT BLANK 


\title{
Hydrogeologic Framework, Arsenic Distribution, and Ground water Geochemistry of the Glacial-Sediment Aquifer at the Auburn Road Landfill Superfund Site, Londonderry, New Hampshire
}

\author{
By James R. Degnan and Philip T. Harte
}

\section{Abstract}

Leachate continues to be generated from landfills at the Auburn Road Landfill Superfund Site in Londonderry, New Hampshire. Impermeable caps on the three landfills at the site inhibit direct infiltration of precipitation; however, high water-table conditions allow groundwater to interact with landfill materials from below, creating leachate and ultimately reducing conditions in downgradient groundwater. Reducing conditions can facilitate arsenic transport by allowing it to stay in solution or by liberating arsenic adsorbed to surfaces and from geologic sources, such as glacial sediments and bedrock.

The site occupies a 180-acre parcel of land containing streams, ponds, wetlands, and former gravel pits located in glacial sediment. Four areas, totaling 14 acres, including three landfills and one septage lagoon, were used for waste disposal. The site was closed in 1980 after volatile organic compounds associated with industrial waste dumping were detected. The site was added to the U.S. Environmental Protection Agency National Priority List in 1982, and the landfills were capped in 1996. Although volatile organic compound concentrations in groundwater have declined substantially, some measurable concentrations remain. Temporally variable and persistent elevated arsenic concentrations have been measured in groundwater affected by the landfill leachate.

Microbial consumption of carbon found in leachate is a driver of reducing conditions that liberate arsenic at the site. In addition to sources of carbon in landfill leachate, wetland areas throughout the site also could contribute carbon to groundwater, but it is currently unknown if any of the wetland areas have downward or reversing gradients that could allow the infiltration of surface water to groundwater. Red-stained sediments and water indicate iron-rich groundwater discharge to surface water and are also associated with elevated concentrations of arsenic in sediment and groundwater. Ironrich groundwater seeps have been observed in the wetland, streams, and pond downgradient of the landfills. Piezometers were installed in some of these locations to confirm groundwater discharge, measure vertical-flow gradients, and to provide a way to sample the discharging groundwater.

Understanding the movement of leachate in groundwater is complicated by the presence of preferential flow paths through aquifer materials with differing hydraulic properties; these preferential flow paths can affect rates of recharge, geochemical conditions, and contaminant fluxes. In areas adjacent to the three capped landfills, infiltration of precipitation containing oxygenated water through permeable deltaic sediments in the former gravel pit area causes increases in dissolved oxygen concentrations and decreases in arsenic concentrations. Layered deltaic sediments produce anisotropic hydraulic characteristics and zones of high hydraulic conductivity. The glacial-sediment aquifer also includes glaciolacustrine sediments that have low permeability and limit infiltration.

Discharge of leachate-affected groundwater may be limited in areas of organic muck on the bottom of Whispering Pines Pond because the muck may act as a semiconfining layer. Geophysical survey results were used to identify several areas with continuous beds of muck and an underlying highresistivity layer on top of a layer of low resistivity that may represent leachate-affected groundwater. The high-resistivity layer is likely groundwater associated with oxygenated recharge, which would cause arsenic to adsorb onto aquifer sediments and reduce concentrations of dissolved arsenic in groundwater.

Surface and borehole geophysical data collected in 2011 were used to identify potentially high-permeability or contaminated zones in the aquifer (preferential flowpaths) as well as low-permeability zones that may promote contamination through back diffusion. Some groundwater in parts of the glacial-sediment aquifer where the leachate plumes were present had low electrical resistivity, low dissolved oxygen, and high concentrations of arsenic. Low-resistivity zones in the underlying bedrock were associated with fractures that also may contain leachate. Although surveying the fractured bedrock was not a specific objective of this study, the results 
suggest that such a survey would help to determine if leachate and associated concentrations of arsenic are migrating downward into the fractured-bedrock-aquifer system.

An uncalibrated, one-dimensional, reactive-transport model was used to assess several conditions that affect arsenic mobility. The results indicate that reductive dissolution and desorption from glacial sediments control dissolved arsenic concentrations. Parameter sensitivity analysis was used to identify key data that are needed in order to accurately assess the time required for arsenic concentrations to fall to levels below the maximum contaminant level at the site. Quantifying this time will require accurate characterization of carbon, sediment-surface sorption sites, and groundwater fluxes at the site.

\section{Introduction}

The Auburn Road Landfill Superfund Site in Londonderry, New Hampshire is a U.S. Environmental Protection Agency (USEPA) National Priority List site with long-term elevated concentrations of arsenic in groundwater. Arsenic concentrations in many wells on and downgradient of the site are above the USEPA maximum contaminant level (MCL) for drinking water (10 micrograms per liter $(\mu \mathrm{g} / \mathrm{L})$; Weston Solutions, 2008). The New Hampshire Department of Environmental Services (NHDES) and the USEPA are concerned with understanding the factors controlling arsenic mobility, transport, and persistence at the Auburn Road Landfill Superfund Site and surrounding area.

\section{Site Background}

The Auburn Road Landfill Superfund site is situated on a 180-acre parcel of land, of which 4 locations totaling 14 acres had been used for disposal (fig. 1). The State of New Hampshire discovered hazardous waste at the site in 1979, and the landfills were closed in 1980. In 1982, the site was added to the USEPA National Priority List. Twenty-two hundred and sixteen waste drums were removed from the landfills from 1986 to 1988. Within a 1-mile (mi) radius of the landfills, 570 homes serviced by private bedrock wells and a private-community supply well (finished in the glacialsediment aquifer) were transferred to the local public-water supply in 1987 because of the threat of contamination by volatile organic compounds (VOCs). The original record of decision (ROD) called for landfill capping and pumping and treating of groundwater, but because of the decline in VOC concentrations, a revised ROD called for the initiation of monitored natural attenuation as an interim remedy (U.S. Environmental Protection Agency, 1997).

Wastes were initially distributed in four locations throughout the site, but were consolidated to three during site remediation efforts. The three landfill sites that remain include the solid-waste landfill, the tire-pile landfill, and the town-dump landfill (fig. 1). The town-dump landfill in the northwest part of the site is on the southern shore of Whispering Pines Pond (fig. 1). Wetlands were constructed as a replacement for those disturbed during landfill operations and capping (U.S. Environmental Protection Agency, 2002) and are upgradient and northwest of the tire-pile landfill. Waste from a former septage lagoon was consolidated into the solid-waste landfill to the southeast. Consolidation of wastes, modification of drainages, and construction of impermeable caps were completed in 1996.

Despite the consolidation of the septage lagoon into the solid-waste landfill, the capping of the three landfills, and the installation of drainage to reduce the generation of landfill leachate, several contaminants persist in the groundwater. The caps are intended to reduce precipitation infiltration into landfill waste, but groundwater continues to flow under the landfills and interacts with wastes in the landfills. Although concentrations of VOCs have declined, concentrations of arsenic remain high. For example, elevated concentrations of arsenic (greater than $10 \mu \mathrm{g} / \mathrm{L}$ ) in groundwater have been reported in samples from monitoring wells in the glacial-sediment aquifer downgradient of the landfills (U.S. Environmental Protection Agency, 2007 and 2012).

\section{Hydrogeologic Setting}

The site is located within a complex hydrogeologic setting that is characterized by glaciofluvial and glaciolacustrine sediments associated Pleistocene glacial lake environments, the remnants of which are common features in New England. Gephart (1985) mapped surficial geologic units for the site and surmised that Pleistocene sediments were associated with three glacial lakes (Wilson, Derry, and Cohas Brook). When the retreating ice margin stood at or near what is now the tire-pile landfill and then later at Whispering Pines Pond, sand and gravel were deposited and graded first into Glacial Lake Derry and then Glacial Lake Wilson, which drained to the south and southwest of the site (Gephart, 1985). Based on topographic contours, glacial-lake levels for these two lakes were about 50 and 30 feet higher in elevation higher than the final glacial lake, Glacial Lake Cohas Brook, which drained to the west into Glacial Lake Merrimack. The well-sorted layering of bedding in the glaciofluvial sediments could cause a directional bias in hydraulic conductivity (anisotropy). Distal portions of the deltas (away from meltwater source) in the glacial-sediment aquifer would have had more uniformly dipping foreset beds. Nearer the former ice margins, however, preferential flow paths are highly variable and are controlled by the orientation of meltwater channels feeding the delta, which would cause spatial variability in hydraulic conductivity (heterogeneity).

Glaciofluvial sediment at the site is at least twice as permeable as the till (Sevee and Maher Engineering, 1992). The glacial sediments at the site are anisotropic because of the layering associated with their deposition, and heterogeneous, with 


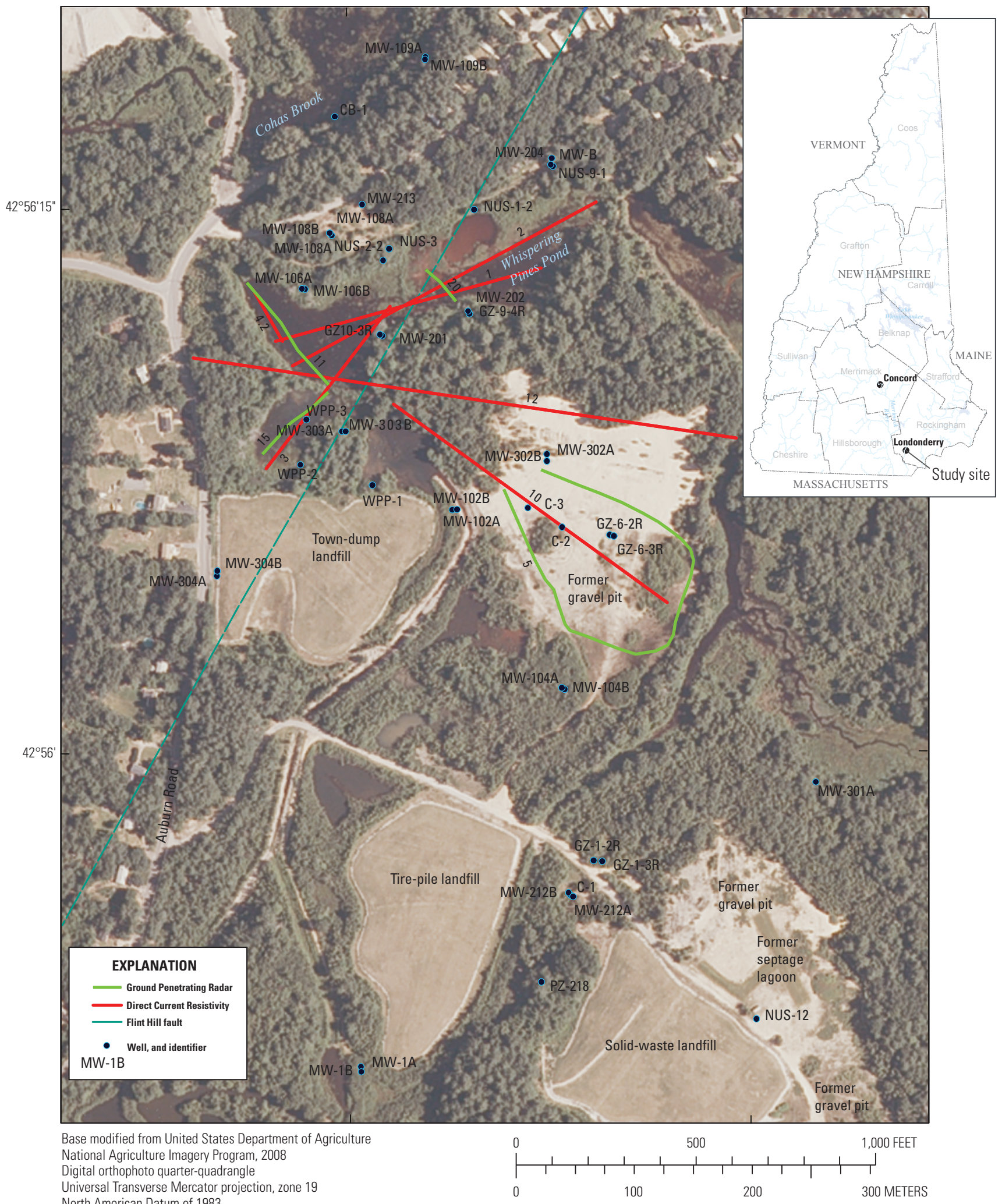

North American Datum of 1983

Figure 1. The location of surface features, wells, and geophysical-survey lines discussed in this report, Auburn Road Landfill Superfund Site, Londonderry, New Hampshire. 
Hydrogeologic Framework and Arsenic Distribution at the Auburn Road Landfill Superfund Site, New Hampshire

hydraulic conductivities as determined from aquifer-tests ranging from 0.074 to 140 feet per day (ft/d), and a mean value of $18 \mathrm{ft} / \mathrm{d}$ (Sevee and Maher Engineering, 1992). Stekl and Flanagan (1992) mapped two high-transmissivity zones (up to 4,000 square feet per day $\left.\left(\mathrm{ft}^{2} / \mathrm{d}\right)\right)$ on and near the site - one at the northern edge of the site extending under Cohas Brook and the other just downstream beneath and to the northwest of Cohas Brook.

Glaciofluvial and glaciolacustrine sediments overlie thin discontinuous till and bedrock. Complex bedrock surface topography (fig. 2) affects groundwater flow within the glacial-sediment aquifer. A bedrock-surface map produced by Sevee and Maher Engineering (1992) shows a north-northeast trending trough that extends from up gradient (south) of the tire-pile landfill to the east side of Whispering Pines Pond. This trough may coincide with the extension of one of several lineaments mapped by Ferguson and others (1997) at and around the site. Lineaments - linear features that may be related to fracture zones - indicate location of potential bedrock fractures that could transmit groundwater at and beyond the site. Other bedrock-surface troughs include a northwesttrending trough starting beneath Cohas Brook and two northeast-trending troughs downgradient of the former septage lagoons and the tire-pile landfill.

The bedrock under the site is mapped as the Berwick Formation, unnamed member, and contains more calc-silicate minerals (15 percent) than other members of the same formation (5 percent) (Lyons and others, 1997). This formation has been associated with regionally high concentrations of naturally occurring arsenic in groundwater that can affect drinking water wells drilled into the formation (Montgomery, 2003; Ayotte, 2003).

Bedrock features that define the bedrock-surface topography affect the geometry of the unconsolidated sediments. The Flint Hill Fault has an undifferentiated direction of motion, though an upper fault block is identified to the northwest (Lyons and others, 1997). This fault trends to the northnortheast through Whispering Pines Pond (fig. 1) and is associated with silicified zones and steeply inclined bedrock topography (Sriramadas, 1966, Freedman, 1950). Though this feature is mostly buried under glacial sediment at the site, it is an important control on the geometry of the glacial-sediment aquifer.

Bedrock and fracture maps to the south of the site further define variations in the Berwick Formation, which, if present at the site, may affect concentrations of arsenic in the bedrock aquifer (Walsh and Clark, 1999). Discrete fracture zones may transmit groundwater and contaminants away from the site. Bedrock fracture zones may play an important role in contaminant transport and the transport of uncontaminated groundwater into the capped landfills. The hydraulic conductivity of the bedrock aquifer, as defined by hydraulic testing of part of the present monitoring well network is low- $4.9 \times 10^{-2}$ to $7.9 \times 10^{-1} \mathrm{ft} / \mathrm{d}$ (Sevee and Maher Engineering, 1992). Similarly, low bedrock-aquifer yields indicating low transmissivity in the Berwick Formation were identified in a regional yield model (Moore and others, 2002), although fracture-correlated lineaments were shown to be associated with some permeable zones in the bedrock.

Groundwater and surface water generally flow to the north and north-northwest from the site towards Cohas Brook (Sevee and Maher Engineering, 1993b), but the direction of shallow groundwater-flow paths may deviate considerably from this pattern - at times flowing south in response to local topography before reversing and flowing north deeper in the flow system. Cohas Brook, to the north of the site (fig. 1), flows west towards the Merrimack River. Groundwater-level data (Weston Solutions, 2009) show upward and downward gradients in adjacent wells completed in the bedrock and overburden, and data from some of the well pairs have gradient reversals. Immediately south of the solid-waste landfill, the topographic divide serves as a groundwater-flow divide. It is unclear whether flow from the replacement wetlands may contribute to higher heads or flow through the waste-site areas.

\section{Arsenic in Groundwater and Contaminants at Landfills}

Arsenic is known to occur naturally in the bedrock, sediment, and groundwater in the region where the landfill is located (Ayotte and others, 2003; Moore, 2004, Montgomery and others, 2003; Robinson and Ayotte, 2006). Arsenic concentrations in water samples collected in 30 percent of bedrock wells installed in the Berwick Formation, unnamed member (Lyons and others, 1997), exceeded the MCL (Montgomery and others, 2003). In the glacial-sediment aquifer, however, Ayotte and others (2003) found that arsenic concentrations in samples from only 3 percent of wells exceeded the MCL of $10 \mu \mathrm{g} / \mathrm{L}$ - largely because the geochemical conditions that inhibit arsenic solubility.

Previous studies indicate that arsenic solubility and transport can be affected by landfill leachate, groundwater hydraulics, and aquifer and groundwater geochemistry. Understanding how these factors operate at this site is necessary to evaluate the potential effects of the site on the environment and to provide for the design of efficient remediation strategies. Potential sources of arsenic at this site include the landfill materials (although evidence that arsenic compounds are in the waste is not currently available) and the geologic materials that form the bedrock and glacial-sediment aquifers. Arsenic from anthropogenic and geologic sources can be mobilized downgradient of waste sites by the mixing of landfill leachate with natural groundwater. This process can create reducing conditions that can enhance (1) the dissolution of oxides containing solid-phase arsenic or (2) desorption of arsenic from metal hydroxides (Whitlock and Kelly, 2010; Hounslow, 1980).

Arsenic mobilization from aquifer sediments as a result of interaction with landfill leachate has been documented in Maine and New Hampshire (Stollenwerk and Colman, 2004; deLemos and others, 2006), and has been shown to be related 

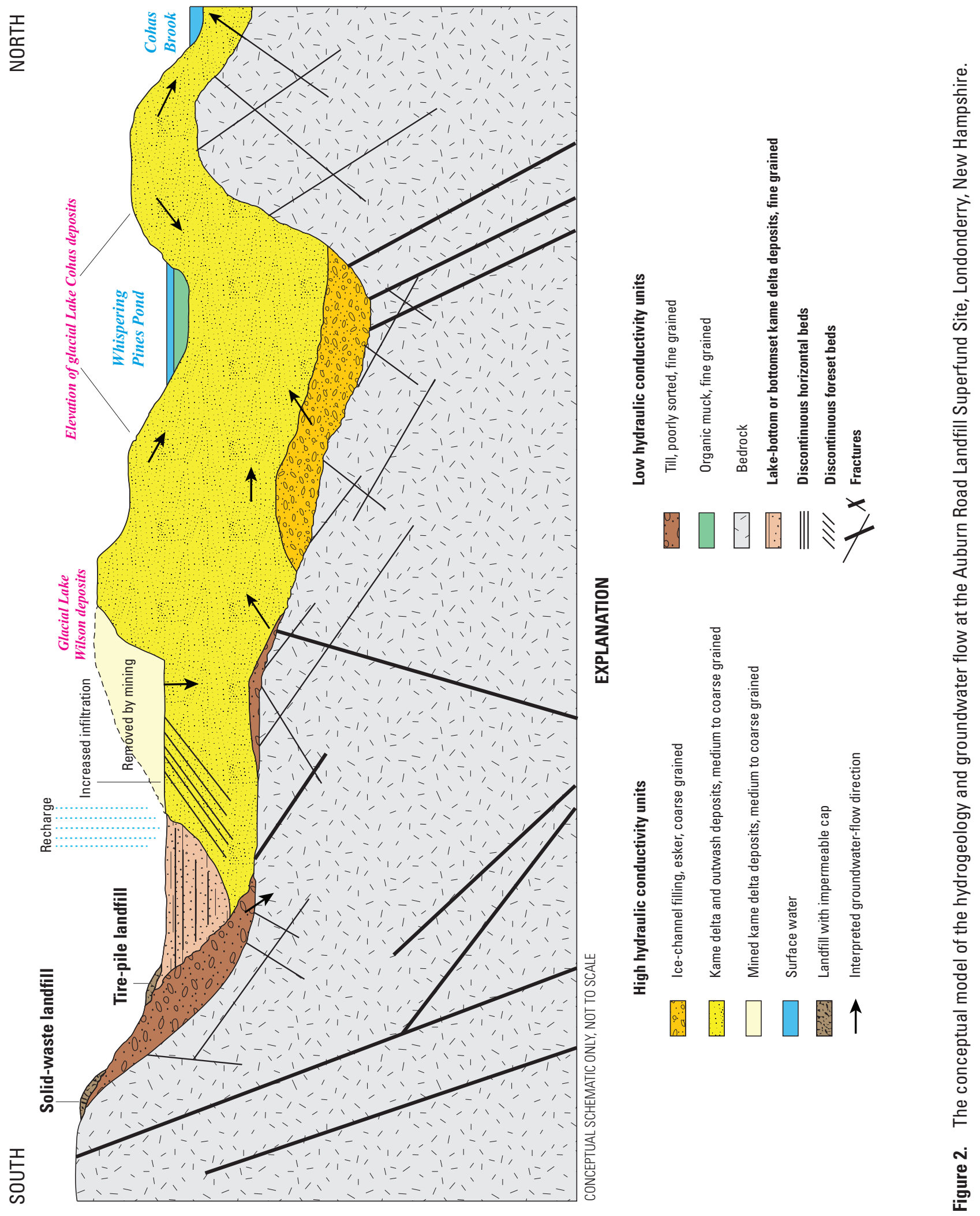
Hydrogeologic Framework and Arsenic Distribution at the Auburn Road Landfill Superfund Site, New Hampshire

to long-term persistence of elevated concentrations of arsenic. For example, reducing conditions created by landfill leachate enhance mobilization of arsenic and iron from iron hydroxides in marine clay at the Coakley Superfund Site, North

Hampton and Greenland, N.H. (deLemos and others, 2006). Concentrations of constituents such as barium, calcium, and ammonium-nitrogen can be used in tracing landfill leachate in groundwater as it discharges to surface water as seeps (Ford and others, 2011).

Previous investigations of landfills in glacial-sediment aquifers by Nielsen and others (1995) and Mack (1995) identified complex layered sediments and leachate-degraded water quality beneath and downgradient of sites. The Norman Landfill, which overlies unconsolidated sediments near Norman, Oklahoma, was found to be sensitive to hydrologic changes, where the upper boundary of the leachate plume was most sensitive to recharge events and seasonal water-table fluctuations (Cozzarelli and others, 2011). For example, concentrations and locations of contaminant discharge to a wetland area at the Norman Landfill varied in response to hydrologic conditions (Lorah and others, 2009). When the water table was low, the plume fringe (where concentrations of contamination were low) intersected and discharged to the center of the wetland. By contrast, when the water table was high, discharge to the wetland was over a broad area, and contaminant concentrations in discharge to the center of the wetland were high. At several wetland and groundwater-discharge locations at the Auburn Road Landfill Superfund Site, hydrologic conditions may affect contaminant transport.

Reactive-transport models for other landfill-affected arsenic-contamination sites have been used to estimate the time required for arsenic concentrations to decline to levels below the MCL. Information from these sites, such as the Saco Landfill Superfund Site in Maine (Stollenwerk and Colman, 2004), has been used to help identify processes that can affect arsenic mobility at the Auburn Landfill Superfund Site.

Selection of methods for and the potential success of remediation efforts at arsenic-contaminated landfill sites depends on the amount of arsenic that needs to be removed from the aquifer materials in order to achieve cleanup goals. Low-permeability glacial sediments, which are associated with back diffusion and slow flushing rates of groundwater along with a complex underlying bedrock fracture system, makes the selection of remedial methods challenging. Quantifying groundwater flow based on a sound conceptual model is helpful in the development of a successful remediation design. Laboratory experiments show that chemical treatments with oxalic acid will mobilize arsenic at sites with pump-and-treat systems in unconsolidated aquifers, such as the Vineland Chemical Company site in New Jersey, which can lead to more efficient remediation (Wovkulich and others, 2010, 2012). Geochemical modeling and laboratory experiments show that enhanced sulfate reduction could reduce arsenic concentrations by immobilizing arsenic within the aquifer at the Winthrop Landfill in Maine (Keimowitz and others, 2011).

\section{Previous Investigations}

In response to initial reports of hazardous waste at the site, remedial site investigations by the NUS Corporation were completed to define the preliminary hydrogeology and contaminant distribution at the site (U.S. Environmental Protection Agency, 1986). Seismic surveys were done in 1985 and 1991 to identify the water table, glaciofluvial sediment, and till and bedrock interfaces. Electromagnetic surveys were used to locate the electrically conductive leachate plume (Sevee and Maher Engineering, 1992). Groundwater observed in wells to be in contact with waste before and after capping of the landfill (Sevee and Maher Engineering, 1993a, Weston Solutions, 2006) created a nearly constant source of leachate.

A detailed predesign investigation for the remediation of groundwater included a hydrogeologic and geochemical characterization completed by Sevee and Maher Engineering (1992) with glacial sediment and bedrock hydraulicconductivity tests, groundwater and surface-water-level monitoring, and groundwater modeling. The investigation used microwells to develop a three-dimensional picture of geochemical conditions, which served to define the location of the arsenic plume. A report on the monitoring results was produced as required by the amended ROD to support the monitored natural-attenuation remedy (Sevee and Maher Engineering, 2000). White and Sevee (1999) found that elevated concentrations of arsenic co-occur with elevated concentrations of iron, manganese, alkalinity, ammonia, and organic carbon at the site. Although arsenic concentrations have decreased slightly in water from wells directly adjacent to landfills, concentrations have remained elevated at downgradient wells. Monitoring of the site by Weston Solutions began in 2000 (Weston Solutions, 2001 annually through 2010). A summary of site references and available data is provided in table 1 .

Tests of soil for total arsenic, along with landfill-leachate experiments with soils in the area of the Auburn Road Landfill Superfund Site, have shown that arsenic occurs in the aquifer sediments and can dissolve into groundwater under chemical reduction-oxidation (redox) conditions described as "reducing" (Sevee and Maher Engineering, 1993b; HydroQual, Inc., 2009). The results indicate that concentrations of arsenic above the MCL could be partly derived from natural sources at the site, but arsenic could be mobilized by reducing conditions associated with the landfill leachate. Arsenic-containing compounds in the waste materials could also be a source of arsenic concentrations in groundwater. A wide range of geochemical conditions at the site and the presence of both arsenic (III) and arsenic (V) indicate multiple processes of mobilization. Redox potential is a major factor related to arsenic solubility and is partially controlled by the amount of total organic carbon (TOC) available in the system. If the amount of landfill leachate (including TOC) is decreasing, or if the redox is affected by an increase in the flow rate of oxygenated groundwater through the aquifer, dissolved arsenic could adsorb onto sediments, and concentrations in groundwater would decrease. 


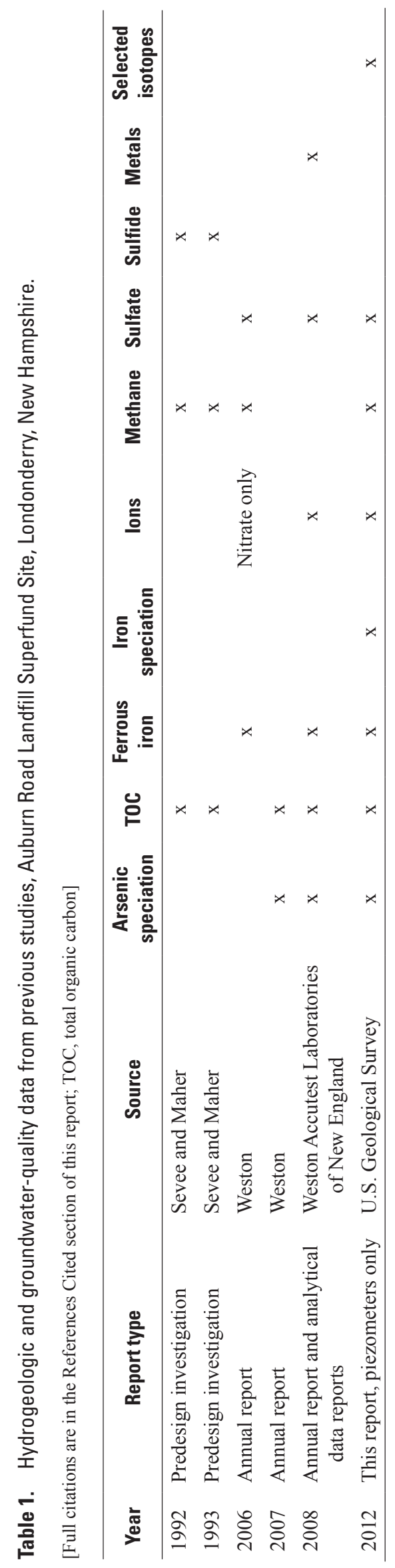


Although not specifically identified, anthropogenic sources of arsenic from materials disposed of in the landfills may include plating wastes, industrial solvents, rat poison, and lead-arsenic pesticides (Richard Hull, U.S. Environmental Protection Agency, written commun., 2012). Arsenic has also been associated with gypsum wallboard material at other sites (Al-Abed and Jegadeesan, U.S. Environmental Protection Agency, 2006) and is a potential source at this site. Geologic or sorbed in-situ (geologic or anthropogenic) sources of arsenic and geochemical processes driven by landfill leachate were modeled by Sevee and Maher Engineering (1993b); the modeling included arsenic release by reductive dissolution of iron and manganese hydroxides.

Geochemical and reactive-transport models coupled to groundwater-flow models have not been developed for the site, although they offer many advantages over current models, such as the ability to simulate redox conditions - an important driver of arsenic mobilization - simultaneously with quantification of groundwater flow. A solute-transport model was developed in response to a request in a 5-year site review (United States Environmental Protection Agency, 2007), and simulations by this model calculated the time required for the arsenic concentrations in groundwater to fall below $10 \mu \mathrm{g} / \mathrm{L}$. The predictions indicate that after 50 years, arsenic concentrations will remain above the MCL in groundwater at the site. For this estimate, the arsenic plume was modeled as a solute that originated from landfill leachate rather than from dissolution of or desorption from iron oxides (HydroQual, Inc., 2009; U.S. Environmental Protection Agency, 2007). The results of the multiple investigations at this site, however, indicate that reducing conditions created by the waste are likely to be one of the major potential causes of arsenic concentrations above the MCL.

\section{Purpose and Scope}

This report describes the results of a U.S. Geological Survey (USGS) study, in cooperation with the NHDES and in collaboration with the USEPA, of the Auburn Road Landfill Superfund Site in Londonderry, N.H. The study objectives were to characterize the hydrogeologic framework of the glacial-sediment aquifer, assess the distribution of concentrations of arsenic in groundwater, identify arsenic transport processes, and to evaluate potential geochemical conditions and geochemical reactions controlling arsenic concentrations at the site. Results from surface-geophysical surveys and borehole logging were used to characterize the hydrogeology as part of this study and were interpreted in the context of existing data to further refine the hydrogeologic framework. A secondary objective was to identify gaps in the understanding of the flow system and processes that affect arsenic concentrations in the groundwater.

\section{Methods of Data Collection and Analysis}

Groundwater geochemistry data from multiple previous studies were analyzed to determine the geochemical evolution of groundwater along flow paths, including indicators of leachate presence, characterization of redox conditions, and concentrations of arsenic and volatile organic compounds in groundwater. The hydrogeologic framework was characterized by surface- and borehole-geophysical surveys in areas downgradient of and surrounding the landfills, including surfacewater bodies. Geologic data from maps, boring logs, and geophysical surveys (collected as parts of previous studies) were used with new data to further refine the characterization of the site. Information regarding geology and chemistry that had been collected for more than 30 years at the time of this study was used to characterize the hydrogeologic framework of the site.

Determining the spatial distribution of geochemical conditions throughout this site is necessary in order to understand the factors that affect the high arsenic concentrations in groundwater. Key factors that may control the concentration of arsenic in groundwater at the site include (1) landfill sources of arsenic, (2) zones of leachate-affected groundwater, (3) zones of reducing groundwater, and (4) zones of oxygenated aquifer recharge. In some cases, groundwater may exhibit mixed redox conditions because oxygenated recharge from precipitation moves downward into leachateaffected groundwater as the groundwater flows from the landfill areas to discharge points along ponds and streams. This can affect the position of the boundary of the arsenic plume spatially and temporally.

Preferential flow paths - zones of high hydraulic conductivity - can move large amounts of leachate-affected groundwater to discharge points and also provide rapid flushing of leachate. Zones of low hydraulic conductivity, in contrast, can result in slow movement of contaminants and provide a steady release of those contaminants over long periods of time. Locating preferential groundwater-flow paths for landfill leachate and identifying reduction and oxidation zones are important for understanding arsenic mobility at the site.

\section{Geophysics and Hydrogeologic Framework}

The hydrogeologic framework of the glacial-sediment aquifer at the site was characterized by using data from new and previous geophysical surveys and well logs (fig. 1; appendix 1). The results allowed identification of locations in the aquifer where groundwater contained leachate and flow paths were associated with zones of high hydraulic conductivity (preferential flow paths). Leachate at landfill sites often results in plumes of high specific conductance that can be mapped in groundwater with electrical geophysical techniques. Mapping the conductive plume also gives general 
insight into the leachate distribution and hydrogeology at landfill sites (Johnson and others, 2002). Locations with thick saturated unconsolidated material are important in the transport process because they transmit large volumes of water for a given hydraulic conductivity. The glacial-sediment aquifer may contain high and low hydraulic-conductivity materials. The former promotes rapid groundwater flow, which can dilute contaminants. The latter results in slow-moving groundwater, which reduces the potential for dilution and may result in back-diffusion of contaminants into groundwater in more permeable zones. Geophysical-survey results and observations of the glacial geology at the site were interpreted on the basis of the systematic active glacial-retreat model presented by Koteff and Pessl (1981).

The results of surface-geophysical surveys and boreholegeophysical logging from this study were used together with previously collected data to enhance the interpretation of the hydrogeologic framework. The locations of geophysical surveys from this study were determined with a global positioning system (GPS) for geospatial referencing in a geographic information system (GIS). This integrated analysis of new geophysical surveys with previously collected geophysical data provided the basis for a refined hydrogeologic characterization. Additionally, seismic refraction data (Sevee and Maher Engineering, 1992) and geologic logs from drilling reports were used to interpret the hydrogeology.

Ground-penetrating radar (GPR) and frequency-domain electromagnetic (FDEM) geophysical-survey methods were used to investigate the shallow hydrogeology of the glacialsediment aquifer. GPR was used to image the water table, pond bottom, sediment bedding, and type of sediment beneath the land and water surface, according to methods described in Beres and Haeni (1991) and Haeni (1996).

Direct-current (DC) electrical-resistivity surveys provided detailed data about the base of the glacial-sediment aquifer. The data were used to calibrate FDEM surveys, which were used to indirectly measure the bulk electrical conductivity of the subsurface with induced electromagnetic signals (Zohdy and others, 1974). Interpretations of results in this report are focused on glacial-sediment-aquifer properties, but because of the depths of the surveys, some information about the fracture network in the bedrock aquifer was also obtained.

Electrical measurements made with FDEM and DC resistivity under ambient groundwater-quality conditions have demonstrated that silt and clay produce a lower resistivity response than sand, which produces a lower resistivity than gravel (Baines and others, 2002). Saturated sand or gravel typically has lower resistivity than unsaturated sand or gravel (Zohdy and others, 1974; Kearey and Brooks, 1991). If the pore water of a sand or gravel is altered by low-resistivity groundwater from anthropogenic or natural sources, the sand or gravel may have low resistivity values that are similar to those of fine-grained aquifer materials (Urish, 1983).

Neutron-porosity, natural gamma-radiation (gamma), and electromagnetic-induction (EM) borehole geophysical logs (Keys, 1990) were collected at selected wells. Logs were completed in polyvinyl-chloride-cased bedrock-aquifer and glacial-sediment aquifer wells and one bedrock-aquifer well cased with steel. Neutron-porosity borehole logs were collected to determine aquifer porosity with depth. Naturalgamma-radiation logs were collected to differentiate finegrained from coarse-grained sediment; lithology and leachateaffected zones can be delineated by combining interpretations from natural-gamma-radiation logs with those from EM borehole logs (Mack, 1993). Geophysical logs were compared to well-construction data to assess the effectiveness of the screen location in the aquifer.

\section{Geochemical-Data Evaluation Methods}

Data from several reports (Sevee and Maher Engineering, 1992, 1993, and 2000; Weston Solutions, 2006; 2007; 2008; 2009, b; 2010), (table 1) were combined to reveal relations among geochemical data, such as redox indicators, specific conductance (SC), and changes in the values of these parameters with time. Geochemical data were examined to identify factors that control, affect, or are correlated with arsenic occurrence and mobility. Spearman correlation (Helsel and Hirsch, 1992) was used to identify relations between parameters suspected to affect SC, concentrations of landfill leachate, and redox indicators. In particular, groundwater SC, which measures the ability of the water to conduct electrical current and is related to the ionic concentration in the water (Hem, 1992), was related to specific groundwater-constituent concentrations and facilitated the interpretation of the electrical response from geophysical surveys. Redox processes were classified into simplified groups by inference from waterquality indicators, such as concentrations of dissolved oxygen, manganese, iron, and sulfate (Jurgens and others, 2009; McMahon and Chapelle, 2008). Geochemical data (Weston Solutions, written commun., 2012) from water samples collected as a part of a 2008 sampling round (Weston Solutions, 2009) were used to determine the apparent redox state of the groundwater. Zones of reducing groundwater were identified by using this simplified redox classification.

The results of redox-state classifications were plotted on cross sections to show the general spatial patterns of the redox zones within the hydrogeologic framework. Groundwater was classified as anoxic if the dissolved oxygen (DO) concentration measured in the field was less than 1 milligram per liter (mg/L). Jurgens and others (2009) classified groundwater as anoxic if the DO concentration was less than $0.5 \mathrm{mg} / \mathrm{L}$, but the threshold was raised up to $1.0 \mathrm{mg} / \mathrm{L}$ for this study to account for any potential inconsistency in measurement methods.

Several arsenic reactions and potential transport rates were investigated by using a simple one-dimensional, uncalibrated, reactive-transport geochemical model (PHREEQC software, Parkhurst and Appelo, 1999). The model was used to simulate the saturated sand and gravel part of the glacial-sediment aquifer. The till and bedrock were not explicitly simulated; however, mixing and diffusion of 
anoxic groundwater from the till was accounted for in some simulations. The reactive component of the model was used to simulate in-situ arsenic sorption-desorption on oxyhydroxide coatings by surface-complexation processes. The transport component of the model was used to simulate steady-state, one-dimensional, uniform groundwater flow along the centerline of the arsenic plume as mapped in 2007 and 2008 (Weston Solutions, 2008, 2009). The model was discretized into 82 cells with a uniform length of $10 \mathrm{~m}$ for a total length of $820 \mathrm{~m}$. The model was not calibrated to field conditions; however, the initial simulated arsenic concentrations were adjusted to equal the average of the arsenic concentrations measured in 2008.

The model was set up to estimate the concentration of dissolved arsenic in groundwater for a hypothetical scenario in which leachate-contaminated groundwater with high TOC concentrations and reducing conditions was exchanged or flushed by oxic, ambient groundwater with low TOC concentrations. The hypothetical scenario was based on the assumption of an instantaneous termination of leachate generation and is relevant to conditions such as future termination of leachate generation. The model did not explicitly account for other processes that may affect arsenic mobility, such as mineral and gas exchange. The model does not account for the complexity of the three-dimensional flow system but does help to identify processes and parameters that affect dissolved arsenic concentrations and to describe the additional data needed to adequately characterize the site and assess the time required for remediation to bring the groundwater into compliance with current groundwater standards. Because additional geochemical and hydrogeologic data are needed to more quantitatively estimate attenuation times, the uncalibrated one-dimensional model simulations focused on the evaluation of parameter sensitivity with respect to rates of arsenic attenuation.

Model input included aqueous geochemical data, surface-complexation data, and estimates of one-dimensional transport rates. Geochemical data for groundwater were selected from available data from the site, but had to be supplemented by data from other sites including the Saco Landfill study (Nielsen and others, 1995), and regional groundwater-chemistry data (Flanagan and Stekl, 1990). Data regarding surface sites (metal oxide coatings on aquifer sediments) for determining surface-complexation reactions (adsorption-desorption from sediments) and exchange rates for aqueous-solid reactions were largely derived from the Saco Landfill study (Nielsen and others, 1995; Stollenwerk and Colman, 2004) because these data were unavailable for this study site. The arsenic concentrations from soil leaching experiments from the Auburn Road Landfill and Saco Landfill sites are nearly equal, suggesting some similarity between the sites (HydroQual, Inc., 2009, table 3-1). Site estimates of groundwater velocities were based on work by Sevee and Maher Engineering (1993a).

\section{Hydrogeologic Framework and Groundwater Geochemistry}

The hydrogeologic framework of the glacial-sediment aquifer at the Auburn Road Superfund Site was analyzed by using data from other studies and geophysical-survey results from this study. Some of the sediments were identified as being associated with zones of high hydraulic conductivity around the three capped landfills (the former septage lagoon was consolidated into the solid-waste landfill) and areas downgradient of the landfills. Spatial relationships between high and low hydraulic conductivity sediments also were examined to better determine their effect on leachate mobility from the three landfill areas. Zones of reducing groundwater at the site were delineated with data collected in the spring of 2008 and are presented in cross sections, and the associated reductive dissolution process was simulated and characterized by using the one-dimensional reactive-transport model.

\section{Hydrogeologic Framework}

The hydrogeologic framework of the glacial-sediment aquifer at the site was characterized by using surface- and borehole-geophysical-survey data and stratigraphic logs (appendix 1, table 1-2). Preferential flow paths associated with zones of high hydraulic conductivity between the three capped landfills and downgradient areas were identified from the data. Spatial relationships between high and low hydraulic conductivity zones affect the movement of leachate, groundwater redox conditions, and the potential for long-term diffusion of leachate, including dissolved organic carbon (DOC) in groundwater, from fine-grained aquifer sediments into coarse-grained sediments. The glacial depositional environment determines the distribution and patterns of sedimentation (Koteff and Pessl, 1981).

Three former hills at the site (mined for sand and gravel) that are shown on the U.S. Geological Survey topographic map (U.S. Geological Survey, 1950) appear to be kame deltas, which are glaciofluvial ice-contact features (Hambrey, 1994) that are coarse grained and have high hydraulic conductivity. The former hills are associated by elevation and location with former glacial lakes mapped by Gephart (1985). All but the northernmost portion of one hill (adjacent and south of Whispering Pines Pond) were removed by a former aggregatemining operation. Dipping foreset beds were identified from GPR survey results within these features along the western portion of line 5 (fig. 1). Adjacent glaciolacustrine sediments (with well-sorted layers) and till (poorly sorted) contain fine-grained and less permeable sediments, which inhibit groundwater flow.

Waste materials are as much as $20 \mathrm{ft}$ thick at the site (Weston Solutions, 2012). Water-level data (Weston Solutions, 2012) from the current monitoring network indicate that groundwater is in contact with as much as $5 \mathrm{ft}$ of waste 
materials at the town-dump landfill (fig. 1). Groundwater was shown to be in contact with waste materials at all three landfills on the basis of waste-altitude and water-level data (Sevee and Maher Engineering, 1993a). Electrically conductive groundwater (possibly indicating high leachate concentrations) was detected in the glacial-sediment aquifer and may also be in some bedrock fractures (figs. 2-5). Groundwater interacting with landfill materials creates plumes of leachate that appear as low-resistivity zones in the DC resistivity and EM surveys (figs. 2-5). By using Archie's Law to convert pore-water SC to bulk resistivity, values ranging from 280 to $140 \mathrm{ohm}$ meters were calculated for sand with pore-water SC of 250 to 500 microsiemens per centimeter at 25 degrees Celsius $\left(\mu \mathrm{S} / \mathrm{cm}\right.$ at $\left.25^{\circ} \mathrm{C}\right)$. These calculated bulk-resistivity values are consistent with values measured in this glacial-sediment aquifer near wells with high arsenic concentrations in groundwater.

Seismic-refraction data (Sevee and Maher Engineering, 1992), geologic logs from drilling reports, and the data collected for this study were used to determine the hydrogeologic framework. Low resistivity (less than $300 \mathrm{ohm}$ meters) measured beneath and downgradient of each of the three landfills was interpreted to indicate electrically conductive landfill leachate (figs. 3-5). High-resistivity values (greater than $1,500 \mathrm{ohm}$ meters) in the unconsolidated sediments below the water table were interpreted to indicate pristine groundwater that may represent background conditions or recently recharged, oxygenated groundwater. Zones of high-resistivity (low-conductivity) groundwater were identified near the surface between the former gravel pit and the southern upgradient edge of Whispering Pines Pond on the eastern edge of DC resistivity line 1 (fig. 1).

Along the center of the sediment-filled valley at the site, the bedrock surface deepens to the north-northeast, subparallel to the Flint Hill Fault (fig. 1, Lyons and others, 1997). The sediments become thicker along the trend of this feature, reaching a maximum thickness of $70 \mathrm{ft}$ beneath Whispering Pines Pond. Geophysical-survey results also indicate prominent bedrock fractures that likely contain electrically conductive landfill leachate. Although this study was not designed to characterize the location and orientation of bedrock fractures, the locations of some of these features were visible and interpreted in the processed data (figs. 3-5).

The solid-waste landfill is on a drainage divide; groundwater in the glacial-sediment aquifer flows east toward a swamp and an unnamed brook and northwest towards the tire-pile landfill. The northwest-flowing groundwater from the solid-waste landfill enters a trough in the bedrock that was filled with approximately $25 \mathrm{ft}$ of saturated glacial sediment (Sevee and Maher Engineering, 1992). Some groundwater in glaciolacustrine (low-hydraulic conductivity) sediments on the western side of the solid-waste landfill combines with groundwater flow from the tire-pile landfill. Groundwater gradients in the spring of 2008 in this area were downward, and flow may also have been entering the bedrock aquifer (fig. 9).
The combined groundwater flow passing by the solidwaste and tire-pile landfills flowed north through fine-grained till and glaciolacustrine sediments before entering the coarsegrained deltaic sediments beneath the former gravel pit. Finegrained sediments inhibit flow, whereas coarse-grained sediments provide pathways for preferential flow. These textures are related to glacial depositional features at the site. Geophysical data can be used to identify these features so that preferential pathways can be mapped systematically. The hydraulic conductivity of the glacial-sediment aquifer increases to the north towards the center of the former gravel pit and north of Whispering Pines Pond (fig. 1, appendix 1, table 1-2), causing groundwater to flow more rapidly.

Fine-grained glaciolacustrine sediment at monitoring well MW-104B, at the southern edge of the former gravel pit and north of the tire-pile landfill, has the lowest overburden hydraulic conductivity measured at the site (table 2).

Glaciolacustrine sediment is indicated here and at the southeast end of line 10 near the surface above the leachate plume as a moderate-resistivity anomaly in the DC-resistivity results (fig. 3). The gamma log from this well indicates layered, fine-grained glaciolacustrine sediment, which is consistent with mapped surficial geologic features (Gephart, 1985). This area is currently vegetated, and water tends to pond during precipitation events, further indicating finegrained sediment near the surface.

The remaining portion of the excavated hill at the north end of the former gravel pit is a drainage divide between the swamps and the stream to the east and the leachateaffected groundwater plume to the west. It is not known whether groundwater contaminated with leachate is beneath the wetland to the east of the site, but EM results indicated that resistivity values in this area are slightly lower than background values, suggesting that the groundwater could contain leachate.

Low-resistivity sediment west of MW-302BR is likely due to the presence of high-conductivity groundwater. Results of DC resistivity surveys indicate that a bedrock trough filled with sediments (and likely leachate-affected groundwater) appears to be immediately west of well MW-302BR (figs. 1, 4). To the west of this trough and downgradient of the towndump landfill (beneath Whispering Pines Pond), the bedrock surface is relatively shallow ( $30 \mathrm{ft}$ or less).

Well MW-302BR intersected and is screened within a 10-ft-thick high-hydraulic conductivity cobble and boulder layer (Sevee and Maher Engineering, 1993b) that may represent a coarse-grained channel filling (such as an esker). This is the only detection of this type of material documented in a drilling log thus far in studies of this site, but if the material is a continuous feature, its extent would be an important control on groundwater flow. GPR records from line 5 indicate a feature that may be cobbles and boulders, but drilling would be needed to confirm this interpretation.

The sediment is thickest beneath the eastern half of Whispering Pines Pond (fig. 5). Low-resistivity (electrically conductive) groundwater is interpreted to be in the sediment 


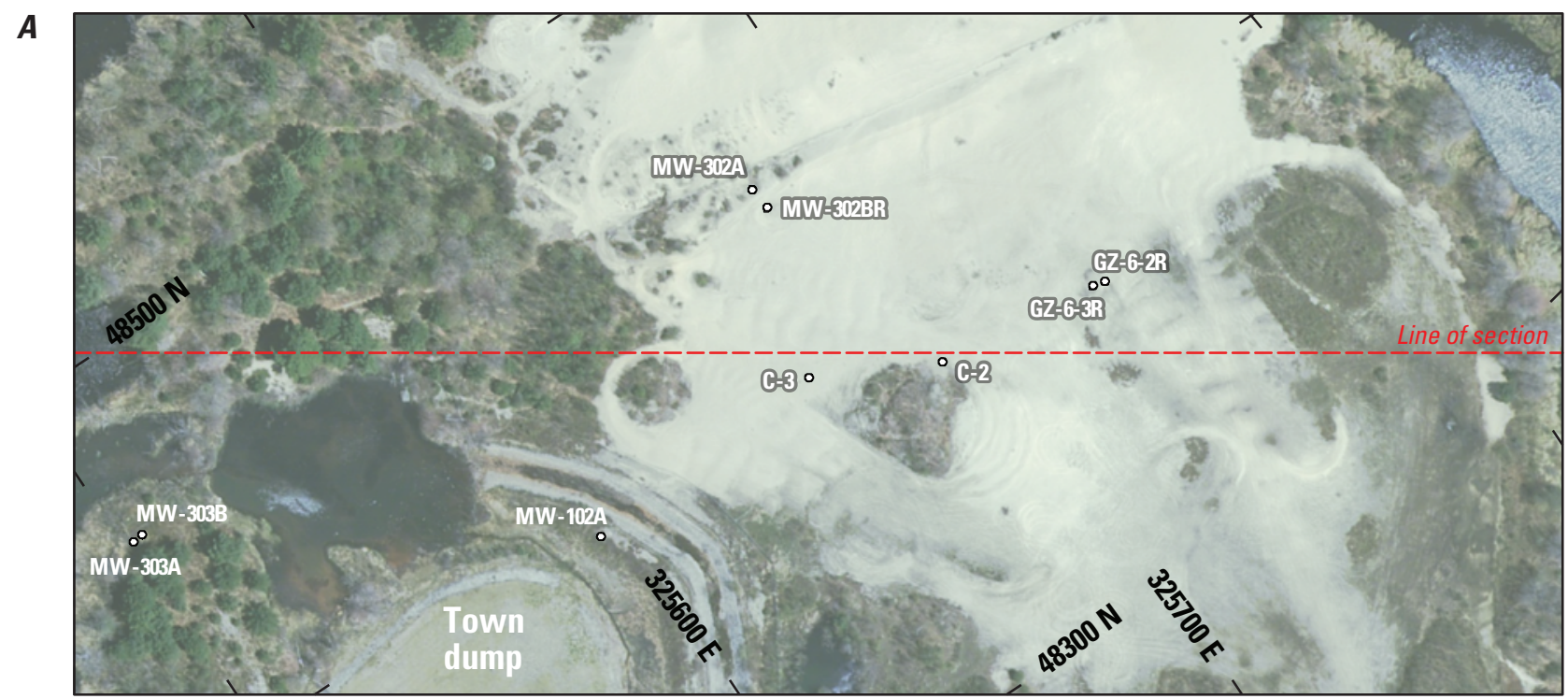

NAD83, Scale 1:3,530

Base photo source: 2005 Natural color 1 -foot pixel files, NH DOT

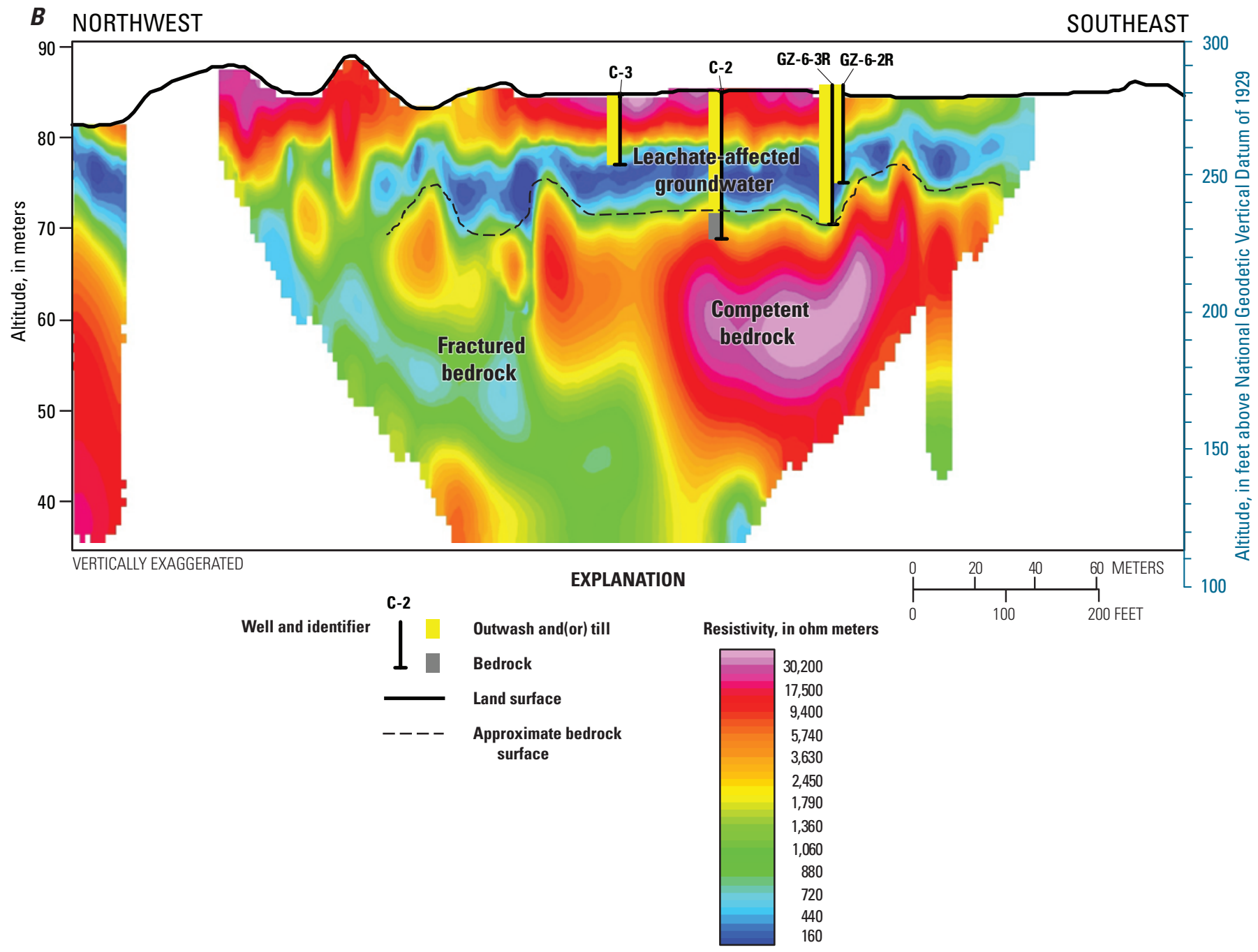

Figure 3. A, Aerial view of the location of line 10 of the direct-current resistivity survey and wells that are projected on the cross section and $B$, cross section showing direct-current resistivity results, July 2011, the altitude of the bedrock surface interpreted from these results, and lithologic logs in wells along line 10 in the former gravel pit, Auburn Road Landfill Superfund Site, Londonderry, New Hampshire. 


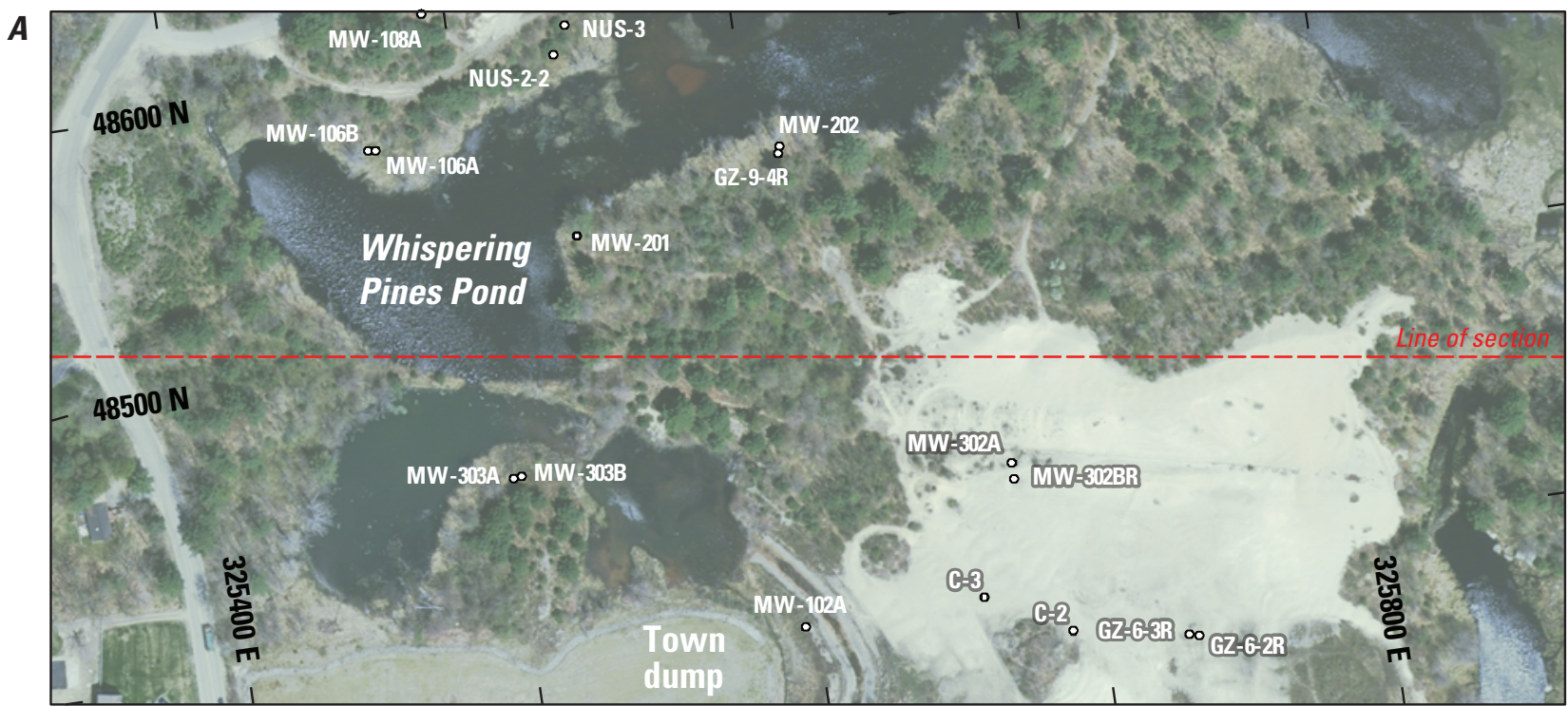

NAD83, Scale 1:3,530

Base photo source: 2005 Natural color 1-foot pixel files, NH DOT

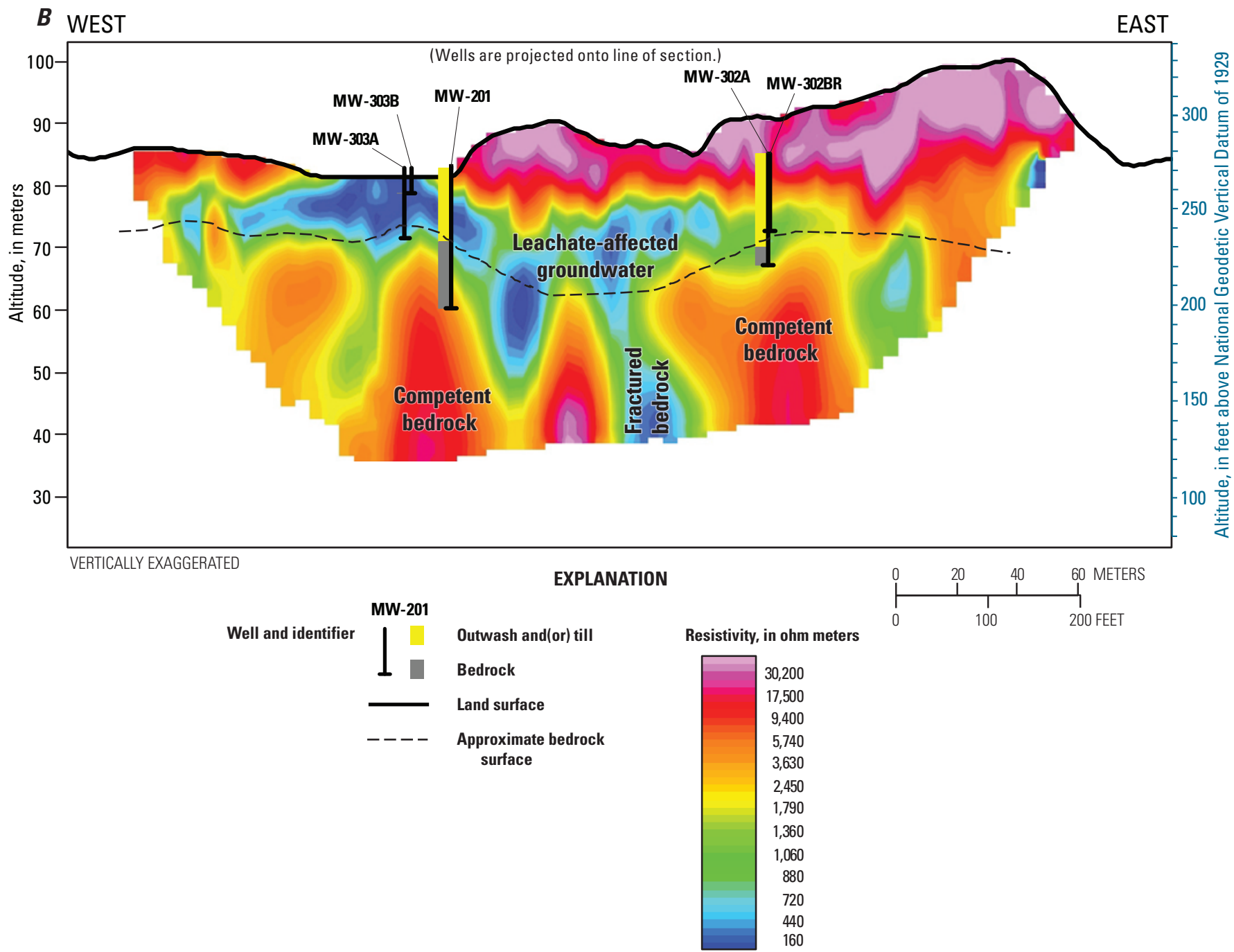

Figure 4. A, Aerial view of the location of line 12 of the direct-current resistivity survey and wells that are projected on the cross section and $B$, cross section showing direct-current resistivity results, July 2011, the altitude of the bedrock surface interpreted from these results, and lithologic logs in wells along line 12, Auburn Road Landfill Superfund Site, Londonderry, New Hampshire. 


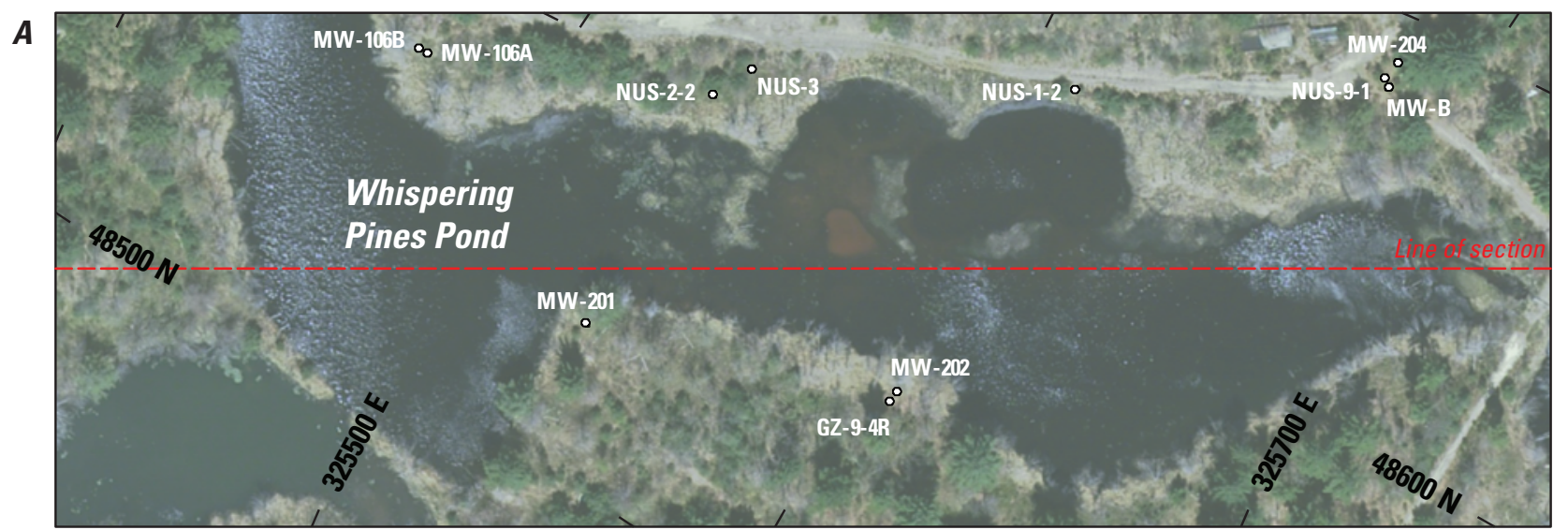

NAD83, Scale 1:3,530

Base photo source: 2005 Natural color 1-foot pixel files, NH DOT

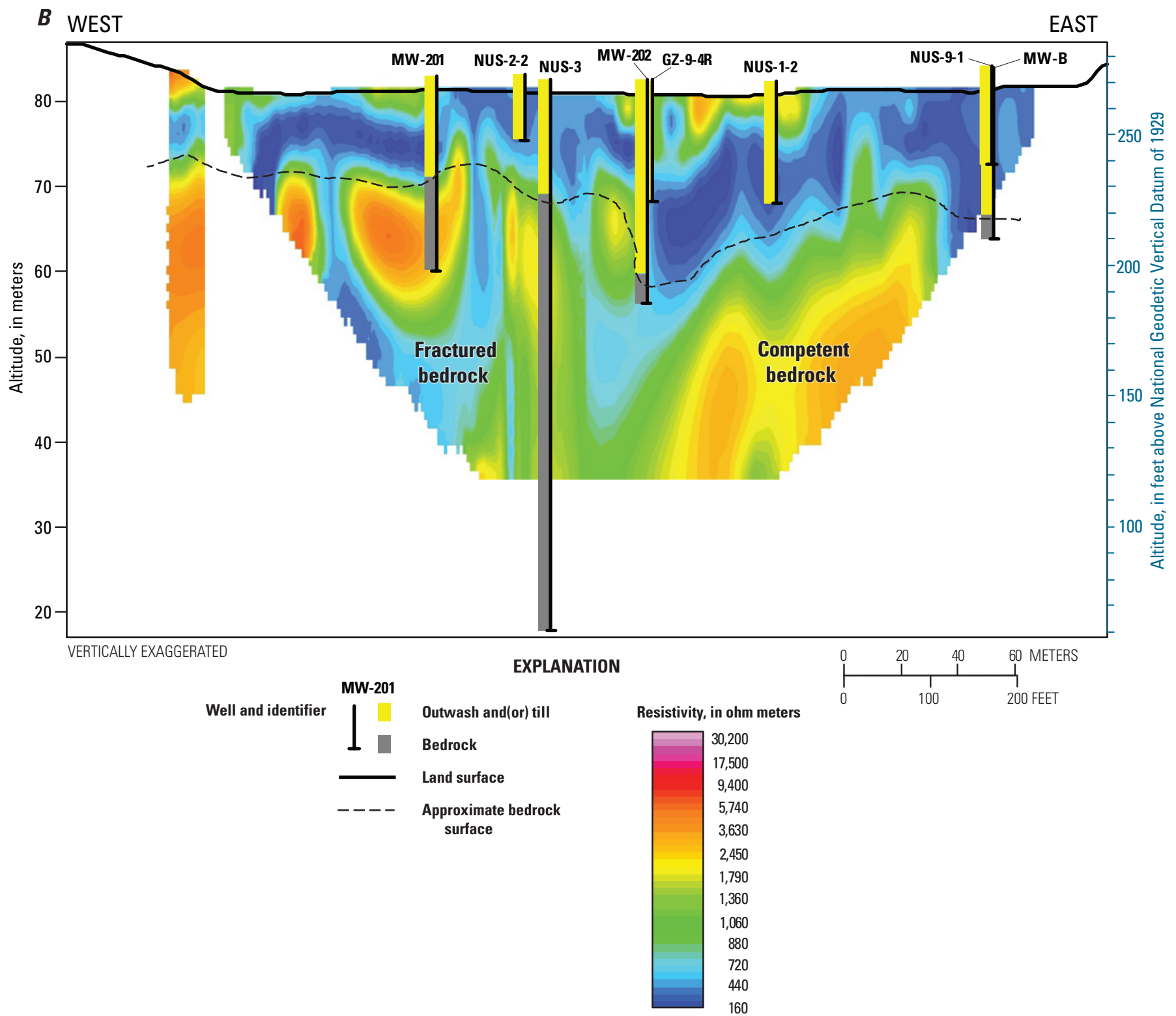

Figure 5. A, Aerial view of the location of line 2 of the direct-current resistivity survey and wells that are projected on the cross section and $B$, cross section showing direct-current resistivity results, February 2011, the altitude of the bedrock surface interpreted from these results, and lithologic logs in wells along line 2 beneath Whispering Pines Pond, Auburn Road Landfill Superfund Site, Londonderry, New Hampshire. 
beneath most of the pond. A prominent red to brown color in the center of the pond may be a groundwater-discharge zone with a plume of iron oxide (reducing groundwater discharges to the pond where it mixes with oxygen and forms an iron precipitate, which is suspended in the water). The plume can be seen on air photos, and it directly overlies a shallow lowresistivity anomaly that extends to the bottom of the bedrock trough (fig. 5). GPR results from line 20 (fig. 1) indicate a depression in the pond-bed sediments penetrating through organic muck into coarse-grained sediments beneath the plume. There is an accumulation of organic muck within the depression, but it is thin in the middle and likely allows water to discharge or recharge the aquifer.

Iron oxide was observed on sediments where groundwater discharges at the edge of the pond and into Cohas Brook. Groundwater also discharges from the toe of the town-dump landfill into the pond and between wells MW-201 and MW-202 on the south shore of the pond (fig. 1). Water levels in piezometers WPP-1 and WPP-2 installed at the toe of the town-dump landfill and WPP-3 indicated groundwater discharge into Whispering Pines Pond, and CB-1 into Cohas Brook, at the time of measurement. It is not known whether flow-gradient reversals occurred at the piezometer locations, but reversals are indicated by historical water-level data (Weston Solutions, 2009) from glacial-sediment and bedrockaquifer well pairs at the site.

Low-permeability organic muck at the bottom of Whispering Pines Pond may inhibit groundwater discharge into the pond. Similarly, this muck layer would inhibit recharge from the pond to the aquifer if the pond-water level were to become higher than the groundwater level. Groundwater that may contain leachate is observed to discharge to the pond where the muck may be thin or absent. High-resistivity groundwater (from recent recharge) on top of low-resistivity groundwater was identified beneath several areas of the pond that have continuous beds of muck indicating no or low rates of groundwater discharge (GPR lines 11 and 15; DC resistivity lines 1, 3, and 4.2; fig. 1). The GPR record is partially attenuated in areas where lowresistivity groundwater is near the pond bottom.

The bedrock surface is higher in altitude downgradient of the pond, restricting flow in the glacial-sediment aquifer. A northeast-trending buried bedrock ridge or ridges identified through seismic refraction surveys (Sevee and Maher Engineering, 1992) and the logs from recently drilled well MW-213 (Weston Solutions, 2010) underlie the trailer park to the north of Whispering Pines Pond. This ridge is co-located and subparallel with the Flint Hill Fault (fig. 1, Lyons and others, 1997) and represents a silicified, erosion-resistant zone in the bedrock surface.

The analysis of borehole-geophysical logs helps assess the effectiveness of the well network in representing the range of hydrogeologic conditions at the site. Logs were interpreted in relation to their screened intervals to determine how effectively the current monitoring network represents the contamination throughout the site. The logs also were used to interpret geochemical conditions, the distribution of arsenic, and the causes of temporal changes in arsenic concentrations. Like water-quality results, some borehole EM-log results vary over time, indicating changes in water quality. The locations of wells in relation to their screened intervals can also be used to delineate water-quality changes over time. Many of the wells completed in the glacial-sediment aquifer are screened over some or all of the most electrically conductive intervals identified in EM logs (appendix 1, table 2). Well C-2 is a bedrock well (without a corresponding well completed in the glacialsediment aquifer) that passes through a conductive EM anomaly between depths of 22 and $36 \mathrm{ft}$ in the glacial sediment. EM results from bedrock well MW-202 indicate that there are two conductive anomalies, including an anomaly in the glacialsediment aquifer between depths of 53 and $59 \mathrm{ft}$, that are not within the screened intervals of any of the wells. Anomalies detected at well depths not intersected by well screens suggest that the current monitoring network may not be suitable for characterizing the current contaminant distribution.

\section{Geochemical Characterization}

The leachate-affected groundwater, associated with high concentrations of arsenic at the site, contains organic carbon and other constituents that are mobilized as a result of groundwater interacting with landfill materials. Temporal transport of leachate through heterogeneous formations with varying permeability can produce differential flow and create back-diffusion. These processes are prominent at boundaries between coarse-grained and fine-grained sediments, but have not been evaluated at the site. Elevated concentrations of TOC were associated with leachate-affected reducing groundwater downgradient of the landfills (Weston Solutions, 2009). The contribution of TOC by wetland sediments to groundwater, if any, is unknown. It is possible that, during some hydrologic conditions, surface water might recharge groundwater, causing wetland-generated TOC to move into the groundwater and reducing conditions to develop.

As a result of leachate generation from the landfills and the microbial consumption of organic carbon - a process that consumes DO in the groundwater - a plume of anoxic groundwater has formed. The leachate plume includes zones of varying levels of redox, from mildly reducing to strongly reducing, which, in turn, have varying effects on arsenic mobilization. Most of the arsenic plume is within the reducing leachate plume. Accordingly, dissolved arsenic in groundwater at the site is mostly in the form of arsenic (III) (Weston Solutions, 2008), which is the reduced form. Arsenic (V) also has been reported as much as 23 percent in well MW-104B. Well MW-104B is in fine-grained low-hydraulic-conductivity glaciolacustrine sediments and is downgradient of the tire-pile landfill. Fine-grained materials also can be a sink for leachatecontaminated groundwater and, through the process of diffusion, may contain groundwater with high concentrations of TOC and arsenic. 
Much of the groundwater in the glacial-sediment aquifer at the site contains concentrations of arsenic that exceed the USEPA MCL for arsenic in public drinking water (Weston Solutions, 2009). Arsenic concentrations are higher in groundwater in the glacial-sediment aquifer than in the bedrock. Fifty percent of samples in the glacial sediment exceeded the MCL for arsenic in 2008. Regionally, the MCL for arsenic in water samples from 3 percent of the wells in the glacial-sediment aquifer has been exceeded (Ayotte and others, 2003), although it is unclear whether percentages might be higher locally.

Elevated SC levels (fig. 6), which were inferred by geophysical surveys during this project (2011), are likely related to high concentrations of calcium, chloride, sodium, iron, and alkalinity (McCleskey and others, 2012). In addition to these elements, low concentrations of iodide and bromide are also typically associated with landfill leachate. Road-salt-affected groundwater (almost exclusively sodium and chloride) was identified adjacent to Auburn Road as a separate plume from the landfill-leachate plume, based on the absence of iodide and bromide (HydroQual, Inc., 2009). Arsenic concentrations in the groundwater of the glacial-sediment aquifer correlate with indicators of leachate, such as specific conductance (fig. 7).

Bromide and iodide concentrations varied spatially in groundwater at the site and can indicate different sources of leachate (landfills). Bromide and iodide were associated with the tire-pile landfill but bromide was more common near the town dump, whereas iodide was more common near the solid-waste landfill. Elevated concentrations of bromide were measured adjacent to the town-dump and tire-pile landfills. Elevated concentrations of chloride were measured adjacent to the town-dump landfill and along Auburn Road. Concentrations of barium and calcium, in addition to potassium, sulfate, isotopes of carbon, bromide, iodide, and chloride concentrations, may have potential for identifying leachate derived from individual landfills.

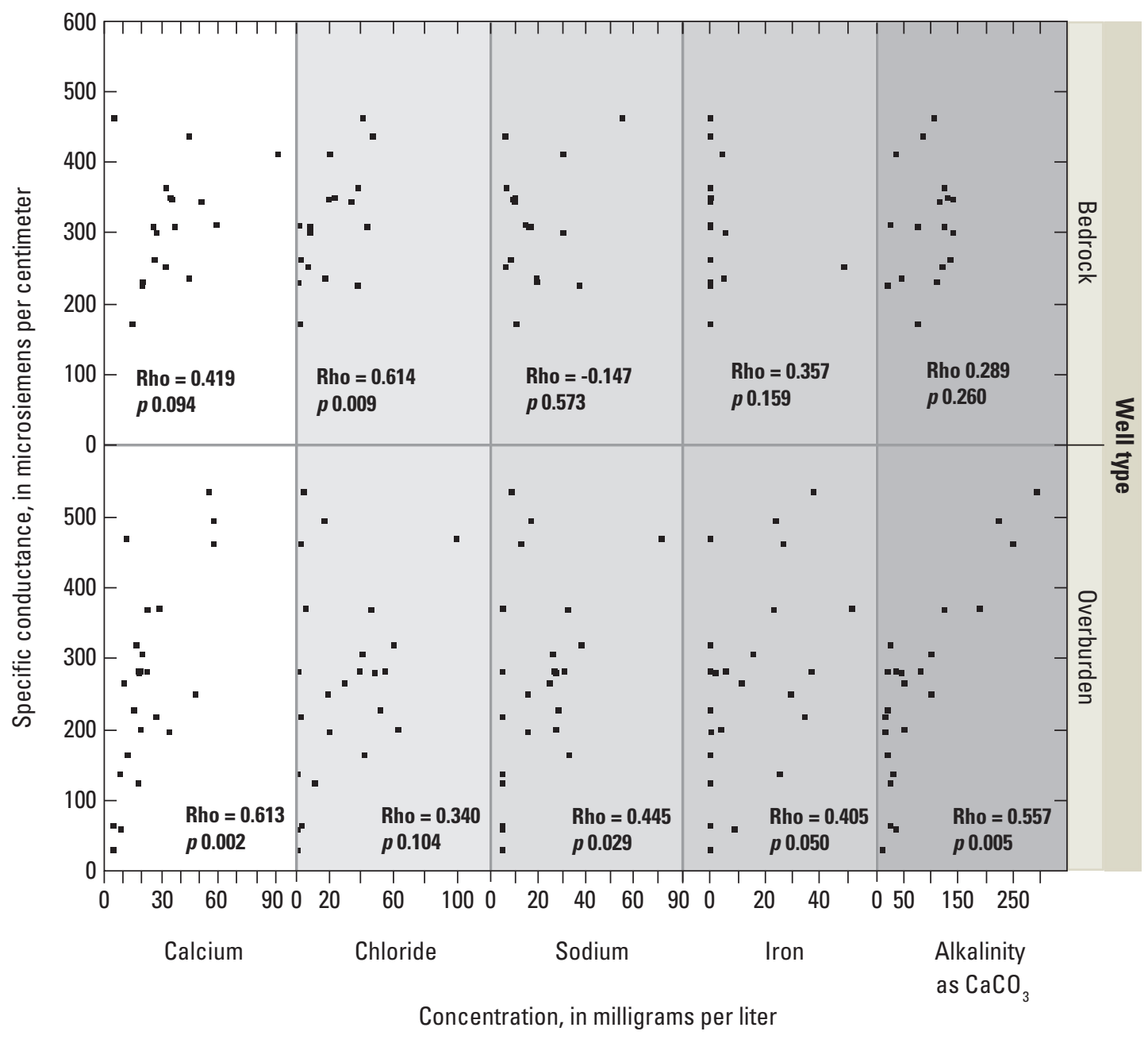

Figure 6. The specific conductance of groundwater as a function of the concentrations of five constituents in water from wells in bedrock and overburden, spring 2008, Auburn Road Landfill Superfund Site, Londonderry, New Hampshire. 
Redox indicators typical of reducing conditions correlated with arsenic concentrations (fig. 8), suggesting that reducing conditions were keeping arsenic in solution. Conversely, sorption of arsenic to aquifer materials under high DO conditions is an important mechanism that limits the mobility of arsenic in groundwater. Manganese reduction, which coliberates manganese and arsenic, may be related to the positive correlation of manganese and arsenic concentrations (fig. 8).

A zone of reducing, methanogenic groundwater was inferred using a simplified redox-classification method that makes use of commonly available data (McMahon and Chapelle, 2008) and was mapped from the tire-pile and solidwaste landfills along the bedrock surface to Whispering Pines Pond. At many arsenic-contaminated sites, dissolved arsenic concentrations are highest in zones of strongly reducing groundwater, such as those indicated by the presence of methane. For example, Harte and others (2012) found a relation between high arsenic concentrations and methane at a nearby waste site in the town of Raymond, N.H.

The outer zones of the plume at the Auburn Road Landfill Site consist of iron- and sulfate-reducing water (fig. 9), which extends from the town-dump landfill under Whispering Pines Pond toward Cohas Brook. Manganese-reducing groundwater was identified on the edges of this plume (fig. 10), which appears to flow along the bedrock surface and through fractured bedrock before discharging at the edge of Cohas Brook (fig. 10). Arsenic has been identified as sorbed to iron oxyhydroxides on the bank of Cohas Brook (Gan and others, 2006; Yu and others, 2010).

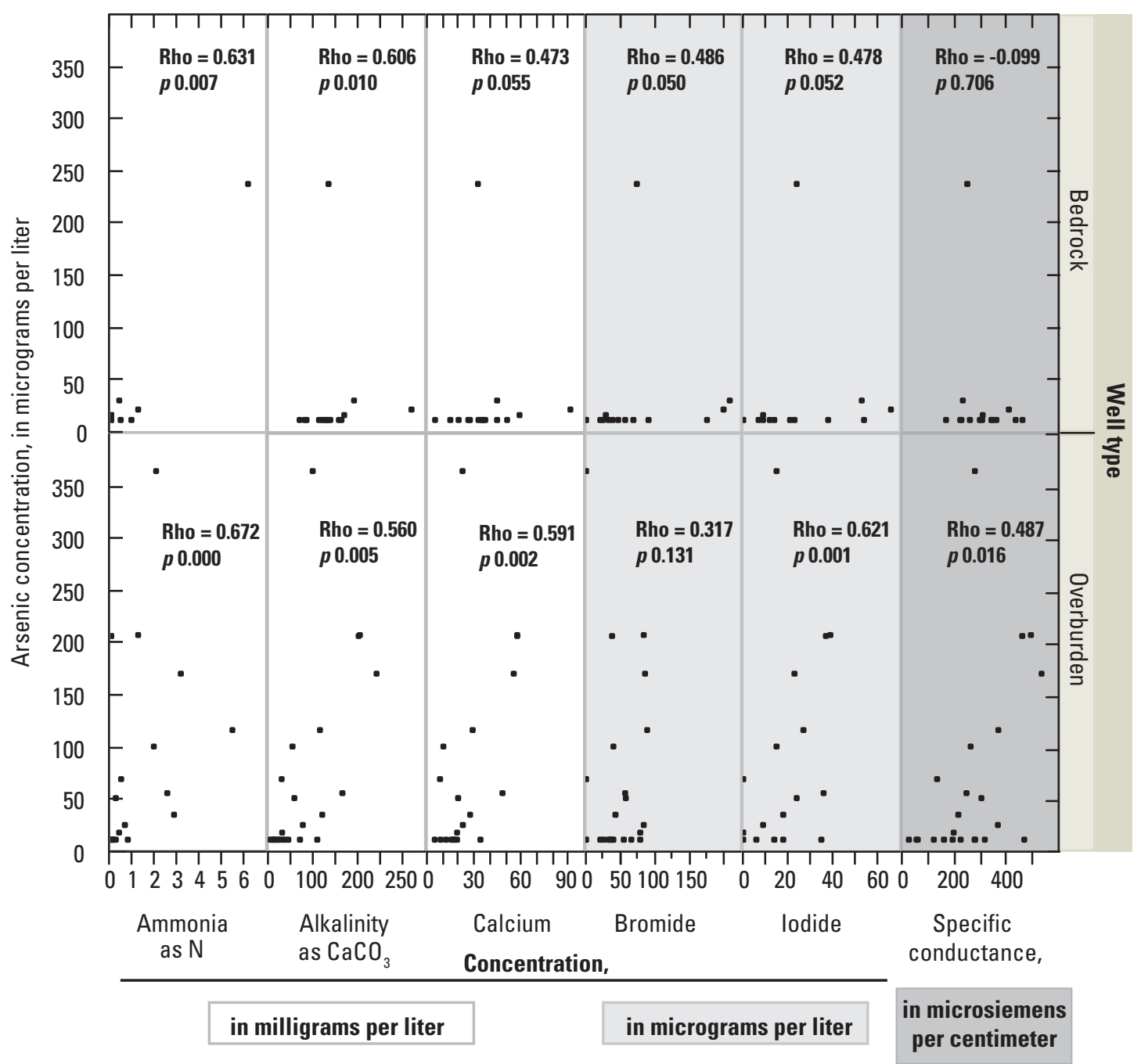

Figure 7. The concentration of arsenic as a function of landfill-leachate indicators in water from wells in bedrock and overburden, spring 2008, Auburn Road Landfill Superfund Site, Londonderry, New Hampshire. 


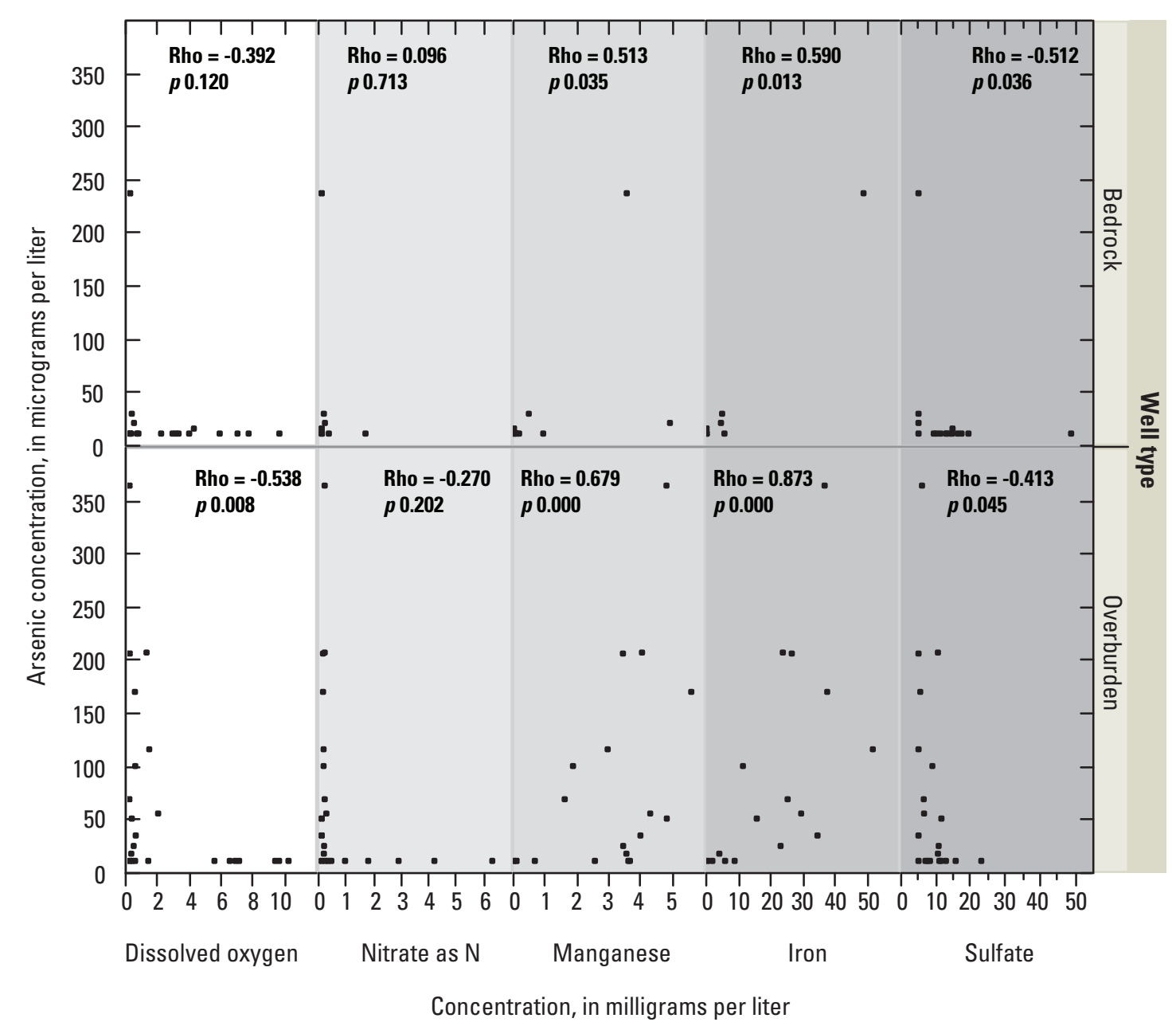

Figure 8. The concentration of arsenic as a function of redox indicators in water from wells in bedrock and overburden, spring 2008, Auburn Road Landfill Superfund Site, Londonderry, New Hampshire.

\section{Persistence of Arsenic}

The persistence of arsenic is a function of physical and chemical processes at the site, such as (1) groundwater interaction with waste materials, (2) generation of leachate, (3) production of a reducing plume of groundwater, and (4) flushing with oxygenated precipitation recharge. Groundwater has continued to interact with landfill materials, generating leachate and arsenic concentrations in groundwater downgradient of the site since the landfills were capped (fig. 11). Precipitation infiltration, capping of landfills, the lowering of Whispering Pines Pond, and beaver activity raising pond-water levels all have an effect on water levels, rates of groundwater flow, leachate generation, redox state, and arsenic dissolution and transport. Furthermore, variability in the wetting and drying of the landfill materials could cause temporal changes in arsenic concentrations downgradient of the landfills and needs to be considered when the temporal results from an individual monitoring well are analyzed.

Wells screened at the edge of the plume and in materials with high permeability have arsenic concentrations that vary substantially compared to wells within the interior of the plume. Concentrations of arsenic in well GZ-6-2R, which is screened in the top part of the high SC plume in the sand layer of the former gravel pit downgradient of the tire-pile landfill, vary more over time (fig. 11B) than those in well GZ-6-3R, which is screened in glacial till within the vertical center of the plume. Concentrations of arsenic in well GZ-6-2R declined since 1994, when the landfill was capped, until 2002 and have remained steady with some nondetections through 2010. Similar variations occurred in well MW-302BR. 


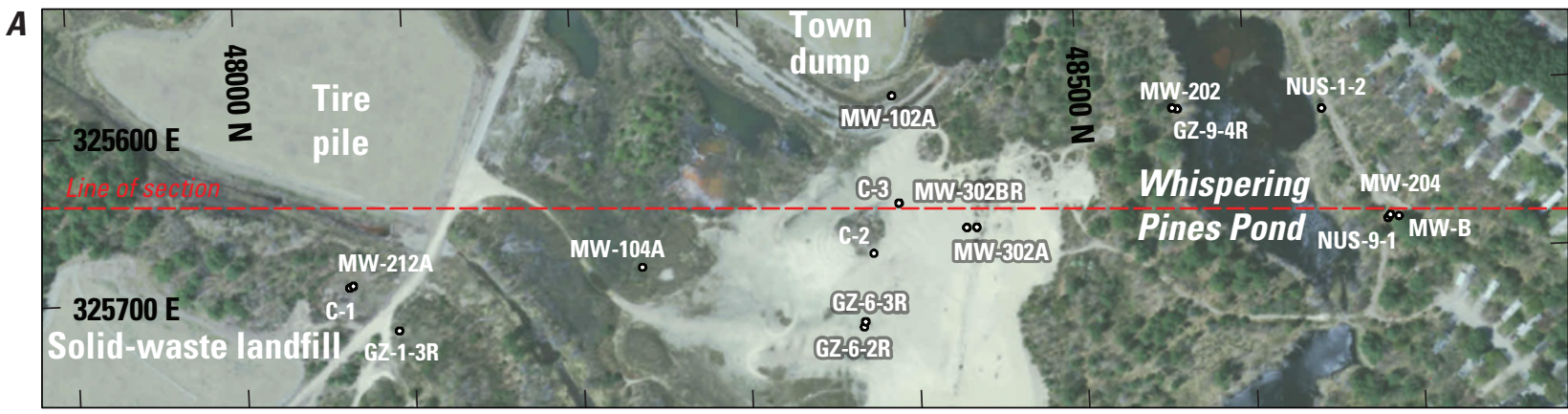

Base photo source: 2005 Natural color 1-foot pixel files, NH DOT

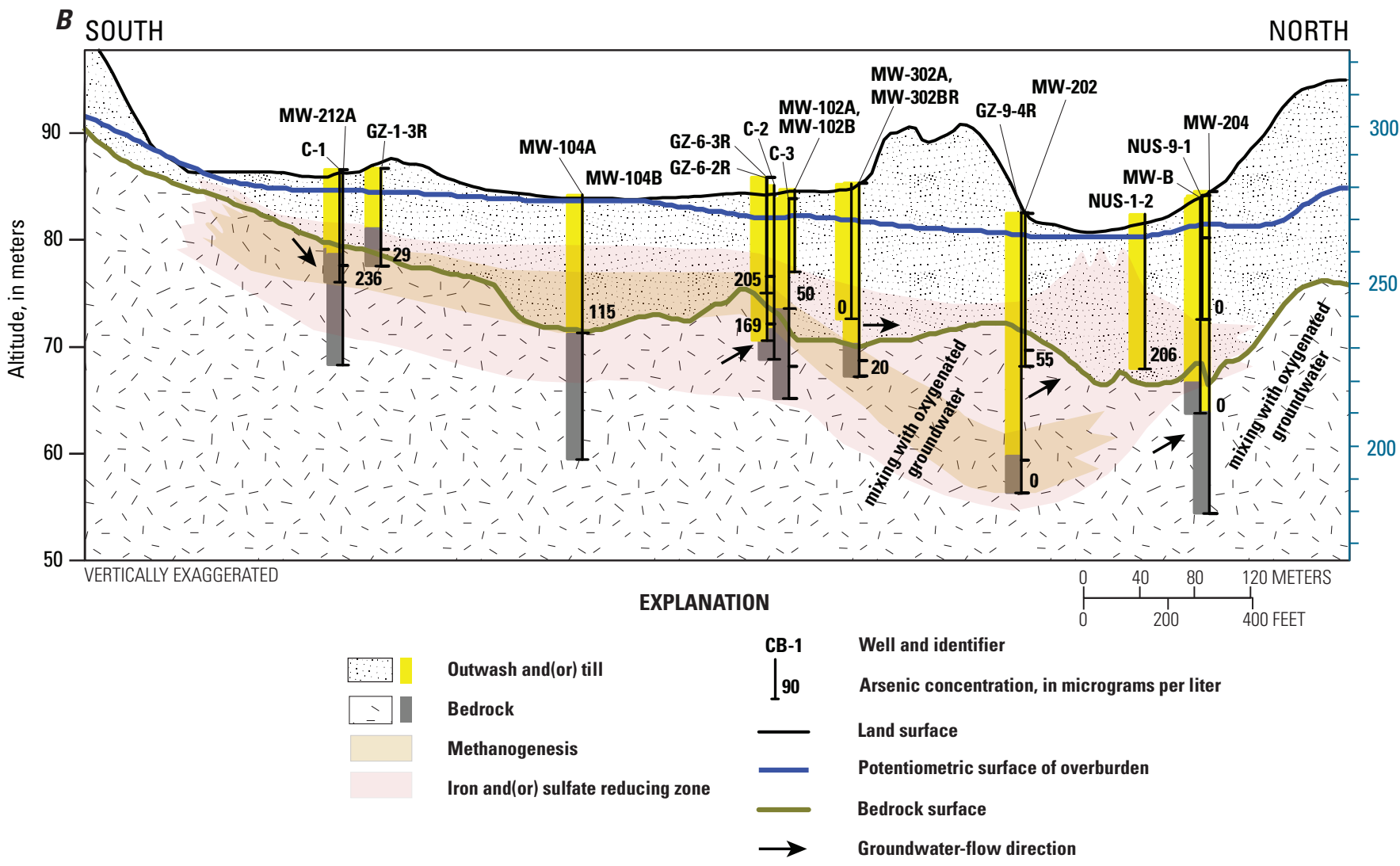

Figure 9. A, Aerial view of the location of the cross section and wells that are projected on the cross section and $B$, cross section showing redox conditions and concentrations of arsenic in groundwater along a flow path from the solid-waste landfill to Whispering Pines Pond, spring 2008, Auburn Road Landfill Superfund Site, Londonderry, New Hampshire. 


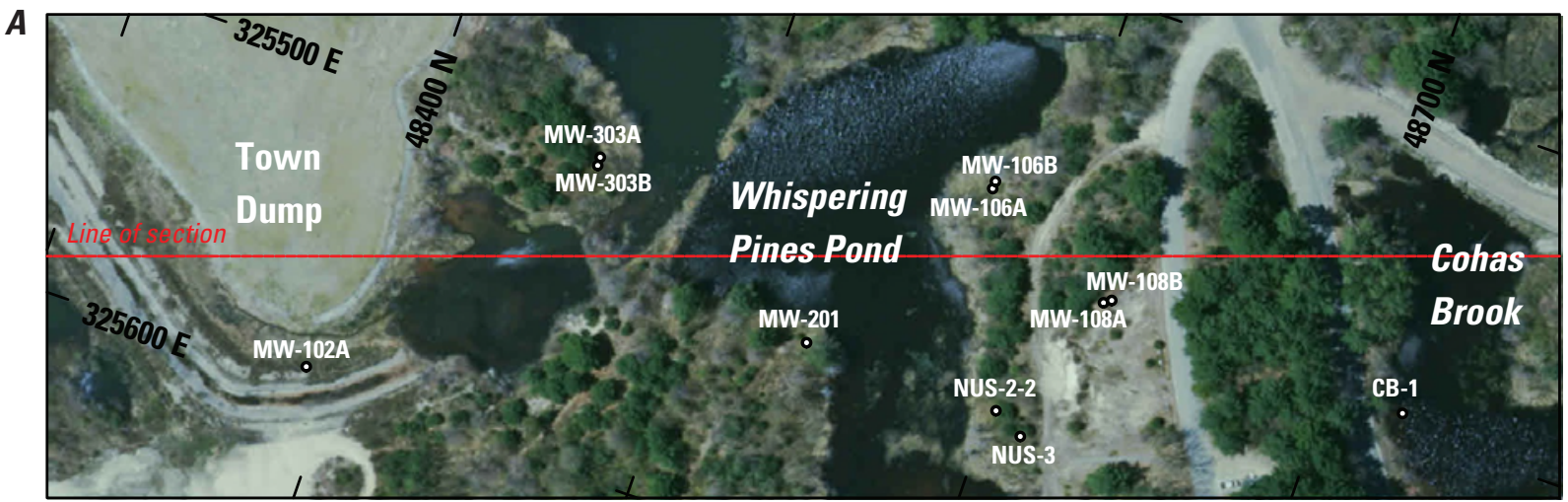

NAD83, Scale 1:3,530

Base photo source: 2005 Natural color 1-foot pixel files, NH DOT

B SOUTH

NORTH

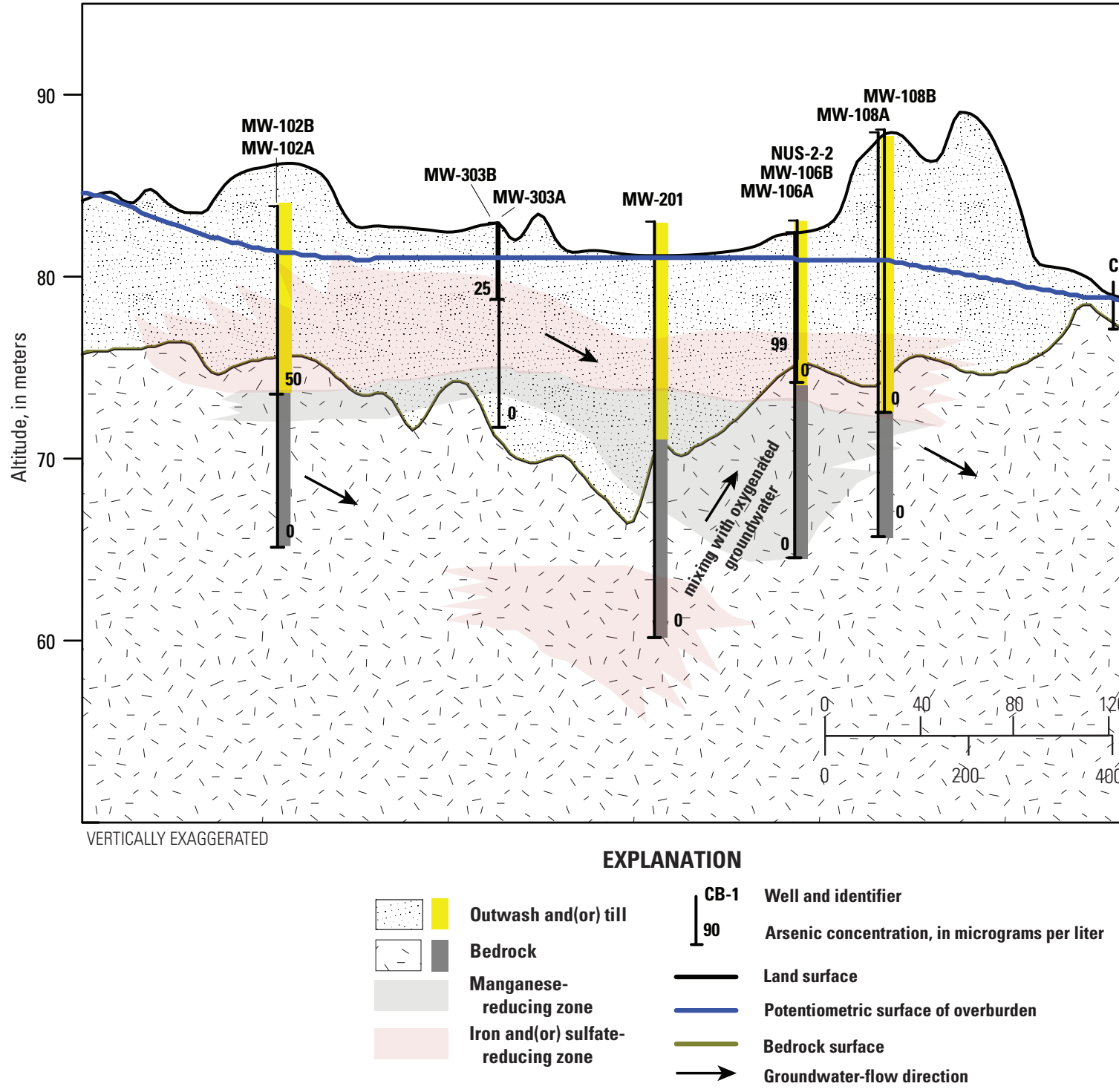

Figure 10. A, Aerial view of the location of the cross section and wells that are projected on the cross section and $B$, cross section showing redox conditions and concentrations of arsenic in groundwater along a flow path from the town-dump landfill to Cohas Brook, spring 2008, Auburn Road Landfill Superfund Site, Londonderry, New Hampshire. 

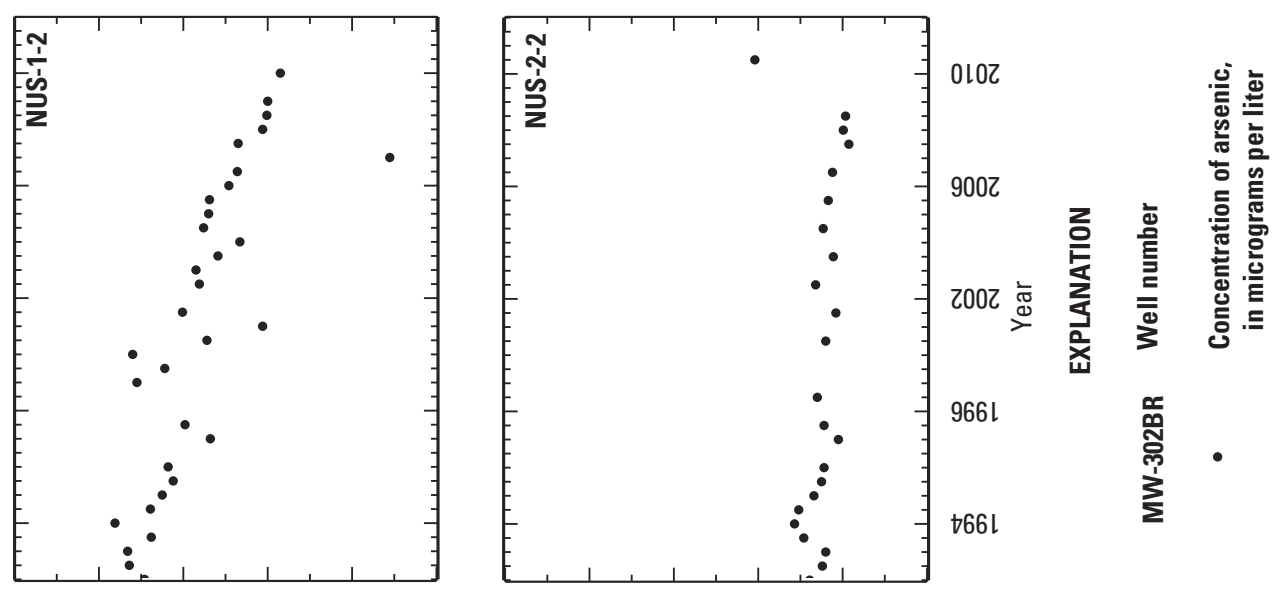

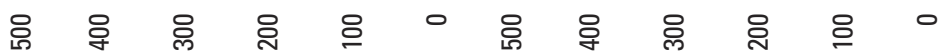

$\omega$
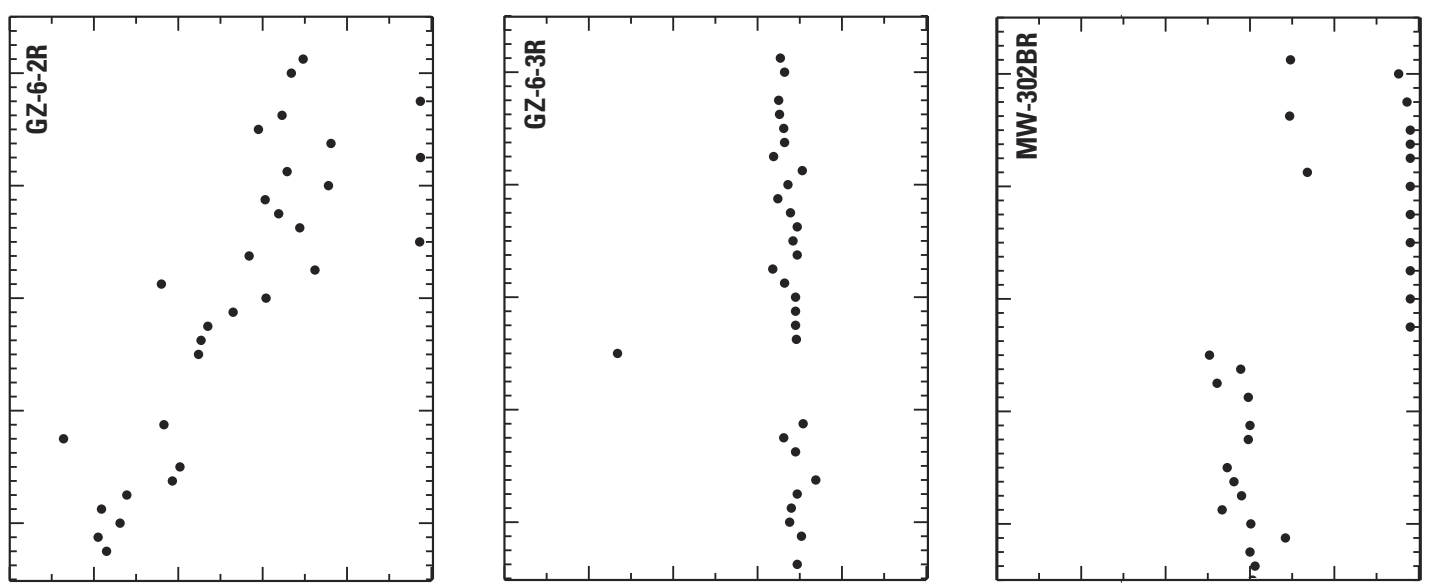

$010 z$
9002
2002
9661
+661
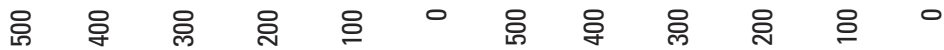

윰 웅 유 응

$\infty$
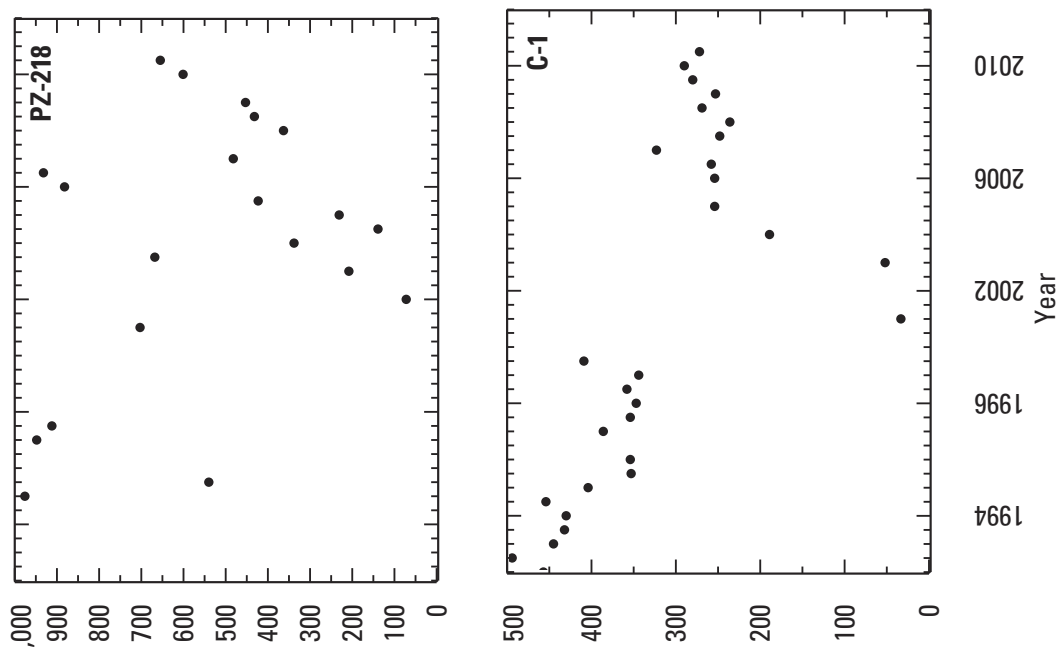

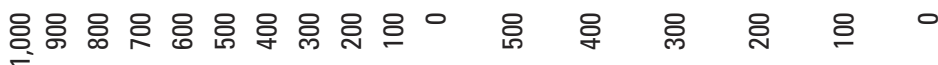


Back-diffusion of contaminants at waste sites is a well-recognized process (Parker and others, 2008). Fine sand and silt zones that have a low permeability can become loaded with contaminants through diffusion as a plume passes by or through the low-permeability zone. (appendix 1, table 2; MW-104B). Differential rates of transport will allow high-permeability zones to flush contaminants more rapidly than low-permeability zones, promoting backdiffusion of contaminants, such as leachate and TOC, from low- to high-permeability zones. Back-diffusion may be affecting concentrations in well MW-104B, where arsenic concentrations are often above $100 \mu \mathrm{g} / \mathrm{L}$. Thus, the contrast in flow between low- and high-transmissivity zones can promote back-diffusion from low- to high-transmissivity zones and provide a long-term continuous source of leachate and arsenic.

The relative importance of several processes and factors affecting arsenic concentrations at the site are important to the decisions that will be made regarding (1) what additional data need to be collected, (2) what additional studies might be warranted, and (3) ultimately, what remedial strategies should be considered. In order to start the process of understanding the relative importance of various factors, a simple onedimensional, uncalibrated, reactive-transport model was developed, and various factors were assessed.

The main objective of the model was to assess the sensitivity of input parameters (representing components of physical and chemical processes) in affecting arsenic attenuation.

Such a sensitivity analysis can lead to a clearer understanding of the factors that are most important in governing arsenic transport. The model was constructed to investigate arsenic mobility under a hypothetical scenario where clean water is flushed through the glacial-sediment aquifer after a hypothetical instantaneous removal of the leachate source. The model primarily simulated redox-driven reactions between the solutes, including ferric oxide, carbon, and arsenic, and mineral surfaces (in the form of surface complexation). The effects of $\mathrm{pH}$ and ion activity on arsenic mobility were accounted for in the surface-complexation reactions; however, these factors had a small effect on dissolved-arsenic concentrations in these reactions. The importance of mineral-exchange or gas-phase reactions, where $\mathrm{pH}$ and ion-activity are known to be important factors, could be assessed with additional geochemicaldata collection and further modeling efforts.

Currently (2012), parts of the solid-waste, tire-pile, and town-dump landfills are under water. The simulations showed that if the source of leachate is removed, the time required for the arsenic concentration to reach the standard is in part dependent on the position along the transport path in relation to the position of the leachate source. Concentrations in the area by Cohas Brook may take the longest to decline because this area is the farthest downgradient. Arsenic concentrations in areas upgradient of Cohas Brook may decrease earlier because the clean water flushes through these areas first.

The number of oxyhydroxide surface-complexation sites on minerals and the velocity of groundwater are key parameters in controlling the time for arsenic concentrations in groundwater to drop below the MCL. A bar graph showing model-parameter sensitivities illustrates the effect of adjusting these parameter values (relative to a base simulation) on the final simulated arsenic (III) concentration (fig. 12A). Arsenic (III) is presented here because it is the primary dissolved arsenic species in the model (appendix 6). The simulated arsenic (III) concentrations in the graphs are from the area by Whispering Pond (fig. 12). Parameters were adjusted typically by less than one order of magnitude from the base simulation except for groundwater velocity, which was adjusted by only 30 percent, to coincide with estimated adjective-transport rates (Sevee and Maher Engineering, 1993a, b). The amount of parameter adjustment was based on either reported literature values or estimated variations. The simulations are grouped according to the parameter adjusted (called coupled parameter simulations).

The sensitivity of a given parameter is partly a function of the parameter adjustment (difference) from the value used in the base simulation. The relation between the time difference and parameter sensitivity for coupled parameter simulations is nonuniform because parameters were not equally adjusted. The model was most sensitive to the potential range in groundwater velocities (fig. 12A), but the largest time difference between coupled simulations occurred when the number of weakly bonded surface sites was increased (fig. 12B). Two types of surface complexation sites-weakly bonded and strongly bonded-were modeled. PHREEQC allows for the simulation of different surface affinities to adsorption and desorption (Parkhurst and Appelo, 1999). Variations in the number of weakly bonded surface sites affected the time to reach the MCL more than the variations in the number of strongly bonded surface sites.

The relative percent time difference to achieve the MCL for arsenic concentrations between the coupled parameter simulations ranged from -33 to 90 percent from the base simulation (fig. 12B). This wide range highlights the need to obtain information on the unconsolidated sediment at the site, particularly the physical and chemical composition. Soil coring in the middle of the plume would allow more accurate determination of the number of binding surfaces available for surface complexation. Higher rates of transport, a lower number of binding surfaces available for surface-complexation reactions, or an increase in the volumes and (or) frequencies of influxes of oxygenated waters would reduce the time to reach the arsenic standard.

Back-diffusion processes - whereby leachate can diffuse out of fine-grained sediments after the leachate plume has been flushed through the bulk of the system - and mixing of both oxic and anoxic groundwater were simulated in the model by use of an additional model layer (parameter mixing, fig. 12B). The mixing of groundwater with high arsenic concentrations diffusing from a modeled till layer (also containing fine-grained sediments) increased cleanup times by 40 percent (parameter mixing; fig. 12B) near Whispering Pines Pond, suggesting that diffusion could significantly prolong the cleanup times at this site. In contrast, the mixing of 


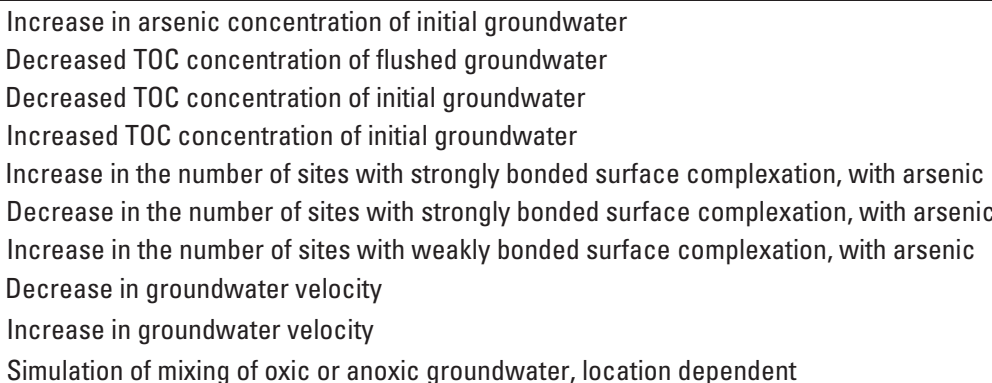


oxygenated groundwater from precipitation recharge with low arsenic concentrations decreased cleanup times by 10 percent in the middle of the transport path by the excavated sand area (fig. 12B; former gravel mine in fig. 1). Simulated recharge of oxygenated water occurs near the excavated sand area and is consistent with an increase in observed DO in this area (fig. 9).

Simulation results show that increasing groundwater velocities by 30 percent reduced the time to achieve the arsenic standard after removal of the leachate source or leachate by -33 percent (parameter velocity 1 ; fig. 12B). This result indicates that increasing hydraulic gradients and velocities could be an effective part of the remedial strategy for the site.

The simulations point to a lack of suitable information to constrain model parameters. For example, equilibrium constants, which control the exchange rates between the surface and aqueous arsenic concentrations, could be as important to determine as the number of surface-complexation sites. Equilibrium constants in the simulations were kept at rates specified for the Saco landfill study in Maine (Stollenwerk and Colman, 2004). Batch column experiments from soil cores at the Auburn landfill would allow estimation of specific equilibrium constants for this site and thus reduce uncertainty in the model. Mineral and gas-exchange reactions were not simulated but could be important factors in dissolved arsenic concentrations. Additionally, the model indicated strong sensitivity to groundwater- flow velocities. To accurately define velocities, a three-dimensional model could be developed. Furthermore, processes such as back-diffusion could be better simulated with a fully three-dimensional model because the total arsenic mass from the till or other low-permeability zones could be better replicated. The development of the model and testing of model parameters highlighted the need for further model development, calibration, and field-data collection to better replicate field conditions.

\section{Data Gaps}

Despite the amount of data that has been collected, gaps remain in the temporal and spatial hydrogeologic and geochemical data for the Auburn Road Landfill Superfund Site. More frequent sampling or sampling driven by hydrologic events, such as changes in water levels, seasons, and precipitation, may explain some of the variations in concentrations in the wells. In addition, the current monitoring network may be inadequate to fully monitor the arsenic and leachate plume. These gaps in data were identified on the basis of results of the new surveys and a reexamination of existing information. Several locations in the deepest part of the glacial-sediment aquifer, which fills bedrock troughs downgradient of the landfills, are not being monitored with existing wells - yet surface resistivity surveys indicate possible contamination with leachate.

Additional data collection and interpretation could be used in the development of a three-dimensional geochemical model of the glacial-sediment and bedrock aquifers to predict the persistence and location of the arsenic plume. Water-level monitoring from surface-water bodies and wells in the existing network could be used to further refine flow directions and gradients. Although past studies have indicated that the groundwater-flow directions are generally to the north and northwest, a variety of localized flow directions and velocities are possible. Continuous water-level-monitoring and horizontal flowmeter measurements will provide flow velocity and directions that can be used to estimate transport rates and the extent of leachate and arsenic contamination. Geophysical data collected for this study indicate the occurrence of leachate-affected groundwater as low-resistivity zones in the glacial-sediment aquifer. Spatial information on the chemistry of the leachate plume mapped with geophysical methods could be determined by calculating the electrical conductivity of the groundwater on the basis of water-quality data by using the methods of McCleskey and others (2012).

\section{Aquifer and Landfill-Matrix Solids}

Little information on the geochemistry of aquifer- and landfill-matrix solids, which is important for assessing the rates of arsenic desorption at the Auburn Road Superfund Site, had been collected at the time this report was completed (2013). Soil cores extracted from the middle of the plume, as well as along boundaries between fine- and coarse-grained sediments, could provide data with which to more accurately determine the number of binding surfaces available for surface complexation. Also, determining the distribution of TOC in each of the hydrogeologic units identified in the conceptual model (fig. 2) would enable a more thorough geochemical evaluation of the arsenic plume. For example, aquifer material consisting of fine sand and silt of low hydraulic conductivity may be a source of leachate and arsenic through backdiffusion from the fine-grained into the coarse-grained parts of the aquifer.

\section{Indicators of Leachate and Groundwater Redox}

Data indicating groundwater redox status and leachate concentrations are not available for many existing and new monitoring wells. These data may be useful in fingerprinting groundwater from individual landfills or portions of landfills. In 1994, prior to the installation of the landfill caps, a detailed monitoring survey of groundwater geochemistry was completed in the glacial-sediment aquifer by using microwells (Sevee and Maher Engineering,1993b). Such a survey, if repeated, would help to determine the effects of capping and two decades of natural attenuation. In addition to the previously measured constituents, analysis of parameters related to the redox state of the groundwater, general groundwater geochemistry, and stable isotopes would facilitate source characterization. This would include, but not be limited to, measurements of groundwater samples for field parameters, isotopes of dissolved organic and inorganic carbon, arsenic, 
VOCs, dissolved gases, and major ions in the glacial-sediment aquifer and the bedrock aquifer.

\section{Surface-Water/Groundwater Interactions}

Groundwater discharge (iron-stained seeps) has been observed, and groundwater/surface-water interactions may control arsenic transport. An understanding of the timing and interaction of groundwater flow with the wetlands, Whispering Pines Pond, and Cohas Brook would be necessary to understand the effects of surface water on groundwater arsenic concentrations at the site. The fate of precipitated compounds that contain arsenic in surface-water sediments and their potential for remobilization are not well understood. Hydrologic variations may affect contaminant transport at several wetland groundwater-discharge locations at the Auburn Road Landfill Superfund Site. The needed surface-water stage, flow, and geochemical data are not available to evaluate these interactions. For example, water-level measurements are needed for Cohas Brook, Whispering Pines Pond, and nearby wetlands. Beaver dams in the pond just north of the town-dump landfill, in the middle of Whispering Pines Pond, and the stream that runs between the tire-pile and solid-waste landfills appear to hold the water at a higher elevation than that of the pond near the dam and outlet to Cohas Brook. Hydrologic and waterquality information collected for specific areas of sediment beneath the pond in the location of geophysical anomalies identified in this study would provide a better determination of groundwater-flow paths. Specifically, drive-point wells from which measurements of water levels and water chemistry could be obtained over a range of depths would provide the type of information needed.

\section{Hydrogeologic Framework of the Bedrock Aquifer}

Bedrock formations, lithology, and fracture patterns, if evaluated, would provide needed information relating to flow into and out of the bedrock aquifer. The bedrock aquifer was not specifically addressed in this study, but some information was acquired during geophysical surveys. Preliminary results from DC resistivity surveys indicate that the underlying fractured bedrock is in hydraulic connection with the glacialsediment aquifer above the bedrock aquifer. Additional geophysical surveys could be designed to determine the orientation and extent of the bedrock fractures.

A detailed assessment of the fractured bedrock aquifer could answer many questions about flow and arsenic contamination at this site. For example, bedrock-borehole and outcrop-fracture characterization along with surface geophysical surveys designed to determine the locations and orientations of bedrock fractures could identify possible contaminant pathways and be used to design a more effective monitoring-well network for the fractured bedrock. Wells installed in these areas would allow for more precise definition of the hydrogeology at specific locations in the bedrock.

Wells already in place (currently not monitored) may be available for inclusion in the enhanced monitoring and bedrock-characterization effort. For example, an open bedrock borehole (NUS-3) on the north side of Whispering Pines Pond is installed deep into the bedrock and could be used to assess arsenic contamination. The results of sampling groundwater at multiple depths in this well could be used to assess whether contaminants are present and what fractures are transporting them. Borehole-flowmeter characterization of the open bedrock could indicate whether cross contamination between the fractures is currently occurring and determine what, if any, preventative actions are needed.

Mapping ductile and brittle features and precisely locating bedrock outcrops at the site would provide information that could be used in the determination of structural patterns of the rock - this information would be used to further map the bedrock surface and to develop model input representing the hydraulic properties of the bedrock. By combining geophysical results with information about the locations of remotely sensed lineaments and fractures, the orientations of larger fracture zones could be determined. Detailed information about locations of outcrops could be used to map the bedrock surface between wells more precisely.

\section{Hydrogeologic Framework of the Glacial- Sediment Aquifer}

The determination of hydrogeologic layers representing hydraulic features in the glacial-sediment aquifer could be remapped with greater resolution. Detailed and current site topography with $2-\mathrm{ft}$ contour intervals could be used to represent the land-surface layer. Prominent topographic (U.S. Geological Survey, 1950) glacial features such as large kame deltas interpreted from quadrangle-scale maps no longer exist. Although their topographic form is no longer identifiable on the land surface, and their influence on precipitation infiltration has been altered, the subsurface remnants of the internal bedding structures of these features have a strong influence on groundwater flow. Conversely, other features that were not represented on older maps are now visible at the land surface, such as bedrock outcrops. The contour of the bedrock surface (figs. $3-5,9,10$ ) could be further refined on the basis of seismic-refraction data collected as part of site investigations in 1985 and 1992; data from microwells, borings installed during precapping investigations, fracture patterns, and ductile structures; and GPS locations of bedrock outcrops around the site. Additionally, data collected from monitoring well MW-213 (drilled in 2009) and seismic data (Sevee and Maher Engineering, 1993) indicate high points in the bedrock surface that may represent a buried bedrock ridge or ridges between Whispering Pines Pond and Cohas Brook. This feature is near the trace of the Flint Hill Fault, which is marked by silicified zones that would represent a significant geologic control 
affecting groundwater flow at the site. Additional geophysical surveys could be collected in areas for which well data are not available to complete the map of the bedrock surface. The organic muck and peat at the bottom of the pond may affect surface-water/groundwater interactions and can be modeled by using available GPR data collected by this study. Estimates of hydraulic conductivity, porosity, and permeability of the aquifer would be useful in the development of a more detailed groundwater-flow model to support a three-dimensional geochemical model. This information could be obtained from available borehole geophysical data (appendix 1) and from additional hydraulic data, including slug-test and nuclear magnetic resonance data, to assign aquifer properties to the entire borehole. An aquifer test would be useful in determining the connectivity between the glacial-sediment aquifer and surface water. Determining the location and extent of high hydraulic conductivity features, such as eskers and other ice-contact glaciofluvial coarse-grained sediments, would be important for modeling preferential pathways for groundwater flow. Additional synthesis of currently available data could be used to create surfaces of stratigraphic units that could inform future modeling efforts.

\section{Groundwater Flow and Three-Dimensional Geochemical Model}

A detailed groundwater-flow model with site-specific data and three-dimensional information about aquifer geochemistry could be used to accurately assess the persistence of arsenic and to test potential remediation schemes. Incorporating reactive-transport into the flow model (coupled flow and transport model) would result in more accurate and representative simulations of conditions across the site. The simulation of processes such as the recharge of groundwater by oxygenated water in the gravel pit would also be possible with the development of a three-dimensional model. The fractured-bedrock aquifer should be included in the model because it is likely an important source of arsenic, according to regional studies of arsenic in New Hampshire (Montgomery and others, 2003).

\section{Summary and Conclusions}

Based on previous investigations and on characterization done for this study, arsenic mobility at the Auburn Road Landfill Superfund Site is attributed largely to reductivedissolution processes involving manganese and iron oxides and (or) reductive desorption of arsenic from those oxides. Also, relatively high dissolved arsenic (V) concentrations at wells (Weston Solutions, 2008) suggest a complex mobilization process. Persistent high arsenic concentrations at the Auburn landfill are produced, in part, from continuous leachate generation from partially submerged waste under the landfills.
Mapping of the arsenic plume is complicated by the complex aquifer heterogeneity at the site; the hydrogeologic framework plays a large role in the spatiotemporal variation of arsenic concentrations. Data from previous studies and new surface and borehole geophysical surveys were used to characterize the hydrogeologic framework of the glacialsediment aquifer between the three capped landfills and downgradient areas at the site. Changes in water levels are affected by recharge (precipitation infiltration) and by varying impoundment of surface water as a result of beaver dams. Leachate-affected groundwater, which contained arsenic, had an electrically conductive signature at this site. This signature allowed for the delineation of leachate by means of geophysical techniques that are sensitive to electrical properties of the groundwater. Sorption and desorption reactions that control arsenic concentrations were studied through the development of a simple uncalibrated, onedimensional, reactive-transport model.

The hydrogeologic framework of the glacial-sediment aquifer is the result of a complex system of till, glaciofluvial, and glaciolacustrine sediments from three overlapping glacial lakes and is further complicated by the topography of the underlying bedrock surface. The remnants of kame deltas (east of the town-dump and solid-waste landfills) form high-permeability zones that lack vegetative cover and provide rapid infiltration of precipitation in the aquifer. Layered low-hydraulic conductivity glaciolacustrine sediment at the site limits infiltration and slows groundwater flow in areas surrounding the kame deltas. The site is underlain by a bedrock trough south of the tire-pile landfill that trends and deepens to the north-northeast towards Whispering Pines Pond. The deep part of the bedrock trough underlies coarse-grained sediments that contain leachate-affected groundwater. A plume of red-tobrown iron oxide in the pond water and iron oxides precipitated on the pond bottom indicate that iron-laden groundwater is discharging to the pond, where the iron is oxidized and precipitated among the pond sediments. It is assumed that groundwater normally discharges to the pond, but it is unclear whether the pond level is sometimes higher than the groundwater level, potentially inducing recharge to the aquifer. Groundwater recharged by precipitation and unaffected by leachate was observed in shallow parts of the aquifer beneath muck on the pond bottom and upgradient (south) of the pond, suggesting that the muck is controlling groundwater discharge to the pond. A northeast-trending, steep, buried bedrock ridge includes erosion-resistant low-permeability silicified zones associated with the Flint Hill Fault. This ridge may be continuous, resulting in a limited saturated thickness that inhibits groundwater flow in the glacial-sediment aquifer.

Groundwater-level data and interpretations from the current monitoring network indicate that groundwater was in contact with wastes at all three landfills, likely generating leachate. Arsenic values were highest at wells adjacent to the solid-waste and the tire-pile landfills and were correlated with iron-reducing and methanogenic redox conditions. A plume of methanogenic groundwater was mapped (by using data from 
2008) from the tire-pile and solid-waste landfills along the bedrock surface to Whispering Pines Pond. Iron- and sulfatereducing conditions were inferred in the outer edges of this plume. A plume of iron- and sulfate-reducing groundwater was flowing from the town-dump landfill under Whispering Pines Pond towards Cohas Brook; the plumes may mix before flowing through fractured bedrock and discharging at the edge of Cohas Brook. The arsenic concentrations were highest in the inferred methane-producing zone.

As part of the assessment, a one-dimensional uncalibrated reactive-transport model was constructed to measure the relative influence of several parameters on dissolved arsenic concentrations. The model simulated hypothetical scenarios that included the removal of the leachate source. Surface complexation (adsorption-desorption of arsenic from oxyhydroxides) was simulated, and the sensitivity of arsenic attenuation to changes in model parameters was evaluated. The results of simulations indicated a high sensitivity to the number of surface sites available for adsorption-desorption. Coring and analysis of aquifer sediments within the arsenic plume could allow investigators to quantify available carbon and the area available on surface sites for adsorptiondesorption to constrain model-parameter values. Groundwater velocity was identified as an important parameter; increasing hydraulic gradients at the site could reduce the time for groundwater to reach arsenic standards if waste generation were terminated. The model does not incorporate aquifer heterogeneity, but results of simulations provide some insight into the potential effect of heterogeneity on remediation and the need to map the subsurface to accurately assess the time required for complete remediation. Enhancements to the monitoring-well network to capture the center and edges (which move according to the varying hydraulics and geochemistry) of the plume as well as to assess the potential contamination of the underlying bedrock would greatly improve the characterization of the arsenic plume. Samples from wells currently (2013) used in the monitoring network that are screened in the top or edge of the conductive leachate plume may detect greater variability in arsenic concentrations as a result of the fluctuating water table or the mixing of geochemically different recharge waters. Without an improved understanding of the hydrogeologic framework and geochemical reactions at this site, projections of long-term trends in arsenic concentrations will have a large uncertainty.

\section{References Cited}

Abraham, Jared, Deszcz-Pan, Maria, Fitterman, David, and Burton, Bethany, 2006, Use of a handheld broadband FDEM induction system for deriving resistivity depth images, in Symposium on the Application of Geophysics to Engineering and Environmental Problems, 19, Las Vegas, Nevada, February 10-14, 2002, Proceedings: Denver, Colo., Environmental and Engineering Geophysical Society CD-ROM, p. 1782-1799.
Al-Abed, Souhail, and Jegadeesan, Gautham, 2006, Arsenic sources and assessement: U.S. Environmental Protection Agency presentation, 26 slides accessed 5/26/2013, at http://www.niehs.nih.gov/news/assets/docs_a_e/arsenic_ sources_and_assessment.pdf.

Ayotte, J.D., Montgomery, D.L., Flanagan, S.M., and Robinson, K.W., 2003, Arsenic in groundwater in eastern New England-Occurrence, controls, and human health implications: Environmental Science \& Technology, v. 37, no. 10, p. 2075-2083.

Baines, Dave, Smith, D.G., Froese, D.G., Bauman, Paul, and Nimeck, Grant, 2002, Electrical resistivity ground imaging (ERGI) - A new tool for mapping the lithology and geometry of channel-belts and valley-fills: Sedimentology, v. 49, p. 441-449.

Beres, Milan, Jr., and Haeni, F.P., 1991, Application of ground-penetrating-radar methods in hydrogeologic studies: Ground Water, v. 29, no. 3, p. 375-386.

Cozzarelli, I.M., Böhlke, J.K., Masoner, J., Breit, G.N., Lorah, M.M., Tuttle, M.L.W., and Jaeschke, J.B., 2011, Biogeochemical evolution of a landfill leachate plume, Norman, Oklahoma: Ground Water, v. 49, p. 663-687, doi:10.1111/ j.1745-6584.2010.00792.x.

Dawson, C.B., Lane, J.W., Jr., White, E.A., and Belaval, Marcel, 2002, Integrated geophysical characterization of the Winthrop landfill southern flow path, Winthrop, Maine, in Symposium on the Application of Geophysics to Engineering and Environmental Problems, 15, Las Vegas, Nevada, February 10-14, 2002, Proceedings: Denver, Colo., Environmental and Engineering Geophysical Society CD-ROM, $22 \mathrm{p}$.

Degnan, J.R., and Harte, P.T., 2012, Characterization of leachate distribution, redox conditions, and the persistence of arsenic in groundwater at the Auburn Rd. landfill site, Londonderry, New Hampshire: Northeastern Section, Geological Society of America, March 18-20, 2012, Hartford, Conn. (Also available at http://nh.water.usgs.gov/Publications/abstracts/jrd_gsa12.htm and http://nh.water.usgs.gov/ presentations/AuburnRdNEGSA04242012.pdf).

deLemos, J.L., Bostick, B.C., Renshaw, C.E., Sturup, S., and Feng, X., 2006, Landfill-stimulated iron reduction and arsenic release at the Coakley superfund site $(\mathrm{NH})$ : Environmental Science \& Technology, v. 40, no. 1, p. 67-73.

Ferguson, E.W., Clark, S.F., Jr., and Moore, R.B., 1997, Lineament map of area 1 of the New Hampshire bedrock aquifer assessment, southeastern New Hampshire: U.S. Geological Survey Open-File Report 96-489, 1 sheet, scale 1:48,000. 
Flanagan, S.M., and Stek1, P.J., 1990, Geohydrologic, groundwater-quality, and streamflow data for the stratified-drift aquifers in the lower Merrimack and coastal river basins, southeastern New Hampshire: U.S. Geological Survey Open-File Report 89-390, 130 p., accessed February 15, 2013, at http://pubs.water.usgs.gov/ofr89-390/.

Ford, R.G., Acree, S.D., Lien, B.K., Scheckel, K.G., Luxton, T.P., Ross, R.R., Williams, A.G., and Clark, Patrick, 2011, Delineating landfill leachate discharge to an arsenic contaminated waterway: Chemosphere, v. 85 , no. 9, November, p. 1525-1537, accessed February 15, 2013, at http://www. sciencedirect.com/science/article/pii/S0045653511010903.

Gan, Ping, Yu, Ran, Smets, B.F., and MacKay, A.A., 2006, Sampling methods to determine the spatial gradients and flux of arsenic at a groundwater seepage zone: Environmental Toxicology and Chemistry, v. 25, no. 6, p. 1487-1495, doi:10.1897/05-402R.1.

Gephart, G.D., 1985, Surficial geologic map of the Derry quadrangle, Rockingham County, New Hampshire: New Hampshire Geological Survey GEO-89, scale 1:24,000.

Haeni, F.P., 1996, Use of ground-penetrating radar and continuous seismic-reflection profiling on surface-water bodies in environmental and engineering studies: Journal of Environmental and Engineering Geophysics Groundwater Geophysics Special Issue, v. 1, no. 1, p. 27-35.

Hambrey, Michael, 1994, Glacial environments: Vancouver, British Columbia, Canada, University of British Columbia Press, 296 p.

Harte, P.T., Ayotte, J.D., Hoffman, Andrew, Révész, K.M., Belaval, Marcel, Lamb, Steven, and Böhlke, J.K., 2012, Heterogeneous redox conditions, arsenic mobility, and groundwater flow in a fractured-rock aquifer near a waste repository site in New Hampshire, USA: Hydrogeology Journal, v. 20, no. 6, p. 1189-1201, accessed February 15, 2013, at http://link.springer.com/article/10.1007\% 2Fs10040-012-0844-4.

Helsel, D.R., and Hirsch, R.M., 1992, Statistical methods in water resources: New York, Elsevier, 529 p.

Hem, J.D., 1985, Study and interpretation of the chemical characteristics of natural water ( $3 d$ ed.): U.S. Geological Survey Water-Supply Paper 2254, 263 p., 3 pls. (Also available online at http://pubs.usgs.gov/wsp/wsp2254/.)

Hounslow, A.W., 1980, Ground-water geochemistry-Arsenic in landfills: Ground Water, v. 18, no. 4, p. 331-333.

Huang, Haoping, and Won, I.J., 2000, Conductivity and susceptibility mapping using broadband electromagnetic sensors: Journal of Environmental and Engineering Geophysics, v. 5, no. 4, p. 31-41.
HydroQual, Inc., 2009, Results of model simulations predicted arsenic cleanup time at the Auburn road landfill, Londonderry, New Hampshire: Mahwah, New Jersey, HydroQual, Inc., 69 p.

Johnson, C.D., Dawson, C.B., Belaval, Marcel, and Lane, J.W., Jr., 2002, An integrated surface-geophysical investigation of the University of Connecticut landfill, Storrs, Connecticut-2000: U.S. Geological Survey Water-Resources Investigations Report 02-4008, 39 p., accessed February 15, 2013, at http://water.usgs.gov/ogw/bgas/publications/ wri024008/.

Johnson, C.D., Haeni, F.P., Lane, J.W., and White, E.A., 2002, Borehole-geophysical investigation of the University of Connecticut landfill, Storrs, Connecticut: U.S. Geological Survey Water-Resources Investigations Report 01-4033, 187 p., accessed February 15, 2013, at http://water.usgs.gov/ ogw/bgas/publications/wri014033/.

Johnson, C.D., Joesten, P.K., and Mondazzi, R.A., 2005, Borehole-geophysical and hydraulic investigation of the fractured-rock aquifer near the University of Connecticut landfill, Storrs, Connecticut, 2000 to 2001: U.S. Geological Survey Water-Resources Investigations Report 03-4125, $133 \mathrm{p}$.

Jurgens, B.C., McMahon, P.B., Chapelle, F.H., and Eberts, S.M., 2009, An Excel ${ }^{\circledR}$ workbook for identifying redox processes in ground water: U.S. Geological Survey OpenFile Report 2009-1004, 8 p., accessed February 15, 2013, at http://pubs.usgs.gov/of/2009/1004/.

Kearey, Philip, and Brooks, Michael, 1991, An introduction to geophysical exploration ( $2 \mathrm{~d}$ ed.): Cambridge, Mass., Blackwell Scientific Publications, $254 \mathrm{p}$.

Keimowitz, A.R., Mailloux, B.J., Cole, P., Stute, M., Simpson, H.J., and Chillrud, S.N., 2011, Laboratory investigations of enhanced sulfate reduction as a groundwater arsenic remediation strategy: Environmental Science \& Technology, v. 41, no. 19 , p. 6718-6724.

Keys, W.S., 1990, Borehole geophysics applied to groundwater investigations: U.S. Geological Survey Techniques of Water-Resources Investigations, book 2, chap. E-2, 149 p., accessed February 15, 2013, at http://pubs.usgs.gov/twri/ twri2-e2/.

Koteff, Carl, and Pessl, Fred, Jr., 1981, Systematic ice retreat in New England: U.S. Geological Survey Professional Paper 1179, 20 p. 
Loke, M.H., 1999, Electrical imaging surveys for environmental and engineering studies-A practical guide to 2-D and 3-D surveys: Stanford University, School of Earth Sciences, 57 p., accessed October 2, 2009, at http://www.agiusa. com/literature.shtml. (Also accessed February 15, 2013, at https://pangea.stanford.edu/research/groups/sfmf/docs/ DCResistivity_Notes2.pdf.)

Lorah, M.M., Cozzarelli, I.M., and Böhlke, J.K., 2009, Biogeochemistry at a wetland sediment-alluvial aquifer interface in a landfill leachate plume: Journal of Contaminant Hydrology, v. 105, nos. 3-4, p. 99-117, doi:10.1016/j. jconhyd.2008.11.008.

Lyons, J.B., Bothner, W.A., Moench, R.H., and Thompson, J.B., Jr., 1997, Bedrock geologic map of New Hampshire: U.S. Geological Survey, scale 1:250,000.

Mack, T.J., 1993, Detection of contaminant plumes by borehole geophysical logging: Ground Water Monitoring \& Remediation, v. 13, no. 1 [winter], p. 107-114.

Mack, T.J., 1995, Hydrogeology, simulated ground-water flow, and ground-water quality at two landfills in Bristol, Vermont: U.S. Geological Survey Water-Resources Investigations Report 94-4108, 120 p., accessed February 15, 2013, at http://pubs.usgs.gov/wri/1994/4108/report.pdf.

McCleskey, R.B., Nordstrom, D.K., Ryan, J.N., and Ball, J.W., 2012, A new method of calculating electrical conductivity with applications to natural waters: Geochimica et Cosmochimica Acta, v. 77, January 15, p. 369-382.

McMahon, P.B., and Chapelle, F.H., 2008, Redox processes and water quality of selected principal aquifers: Ground Water, v. 46, no. 2, p. 259-271.

Montgomery, D.L., Ayotte, J.D., Hamlin, Patricia, and Caroll, P.R., 2003, Arsenic concentrations in private bedrock wells in southeastern New Hampshire: U.S. Geological Survey Fact Sheet 2003-051, 8 p., accessed February 15, 2013, at http://pubs.usgs.gov/fs/fs-051-03/.

Moore, R.B., 2004, Quality of water in the fractured-bedrock aquifer of New Hampshire: U.S. Geological Survey Scientific Investigations Report 2004-5093, 30 p., accessed February 15, 2013, at http://pubs.usgs.gov/sir/2004/5093/.

Moore, R.B., Schwarz, G.E., Clark, S.F., Jr., Walsh, G.J., and Degnan, J.R., 2002, Factors related to well yield in the fractured-bedrock aquifer of New Hampshire: U.S. Geological Survey Professional Paper 1660, 51 p., 2 pls., accessed February 15, 2013, at http://pubs.usgs.gov/pp/pp1660/.
Nielsen, M.G., Stone, J.R., Hansen, B.P., and Nielsen, J.P., 1995, Geohydrology, water quality, and conceptual model of the hydrologic system, Saco landfill area, Saco, Maine: U.S. Geological Survey Water-Resources Investigations Report 95-4027, 94 p., accessed February 15, 2013, at http://toxics.usgs.gov/pubs/wri95-4027.html.

Parker, B.L., Chapman, S.W., and Guilbeault, M.A., 2008, Plume persistence caused by back diffusion from thin clay layers in a sand aquifer following TCE source-zone hydraulic isolation: Journal of Contaminant Hydrology, v. 102, no. 1-2, p. 86-104.

Parkhurst, D.L., and Appelo, C.A.J., 1999, User's guide to PHREEQC (version 2) - A computer program for speciation, batch-reaction, one-dimensional transport, and inverse geochemical calculations: U.S. Geological Survey WaterResources Investigations Report 99-4259, 312 p., accessed February 15, 2013, at http://pubs.usgs.gov/wri/1999/4259/ report.pdf.

Robinson, G.R., Jr., and Ayotte, J.D., 2006, The influence of geology and land use on arsenic in stream sediments and ground waters in New England, USA: Applied Geochemistry, v. 21, no. 9, p. 1482-1497.

Sevee and Maher Engineering, 1992, Pre-design investigation report for remediation of groundwater, Auburn road landfill site: Londonderry, N.H., Sevee and Maher Engineering, 2 vols.

Sevee and Maher Engineering, 1993a, Supplemental predesign investigation for remediation of groundwater, supplement I of Pre-design investigation report for remediation of groundwater, Auburn road landfill site: Londonderry, N.H., Sevee and Maher Engineering, variously paginated.

Sevee and Maher Engineering, 1993b, Supplemental predesign investigation for remediation of groundwater, supplement II of Pre-design investigation report for remediation of groundwater, Auburn road landfill site: Londonderry, N.H., Sevee and Maher Engineering, 2 vols., variously paginated.

Sevee and Maher Engineering, 2000, 1999 annual report, environmental monitoring program, Auburn road superfund site: Londonderry, N.H., Sevee and Maher Engineering, variously paginated.

Sriramadas, A., 1966, Geologic map and structure sections of the Manchester quadrangle, New Hampshire: New Hampshire Department of Resources and Economic Development, scale 1:62,500, $1 \mathrm{pl}$. 
Stek1, P.J., and Flanagan, S.M., 1992, Geohydrology and water quality of stratified-drift aquifers in the lower Merrimack and coastal river basins, southeastern New Hampshire: U.S. Geological Survey Water-Resources Investigations Report 91-4025, 75 p., plus 1 appendix, accessed February 15, 2013, at http://pubs.usgs.gov/wri/wrir_91-4025/.

Stollenwerk, K.G., and Colman, J.A., 2004, Natural remediation of arsenic contaminated ground water associated with landfill leachate: U.S. Geological Survey Fact Sheet 2004-6057, 4 p., accessed February 15, 2013, at http://pubs. usgs.gov/fs/2004/3057/.

Urish, D.W., 1983, The practical application of surface electrical resistivity to detection of ground-water pollution: Ground Water, v. 21, no. 2, p. 144-152, doi:10.1111/j.1745-6584.1983.tb00711.x.

U.S. Environmental Protection Agency, 1989, Auburn road landfill, EPA ID NHD980524086, OU 02, Londonderry, N.H.: U.S. Environmental Protection Agency EPA/ROD/ R01-89/042, September 29, 1989, 38 p.

U.S. Environmental Protection Agency, 1997, Auburn road landfill, EPA ID NHD980524086, OU 02, Londonderry, N.H.: U.S. Environmental Protection Agency EPA/AMD/ R01-97/003, December 19, 1996, 35 p.

U.S. Environmental Protection Agency, 1997, Auburn road landfill superfund site-Five-year review: U.S. Environmental Protection Agency 5-year review (2d), September 1997, 8 p.

U.S. Environmental Protection Agency, 2002, Third five-year review report for the Auburn road landfill superfund site, town of Londonderry, Rockingham County, New Hampshire: U.S. Environmental Protection Agency, September 2002, $63 \mathrm{p}$.

U.S. Environmental Protection Agency, 2007, Fourth five-year review report for Auburn road landfill superfund site, town of Londonderry, Rockingham County, New Hampshire: U.S. Environmental Protection Agency, September 2007, $127 \mathrm{p}$.

U.S. Environmental Protection Agency, 2012, Fifth five-year review report for Auburn road landfill superfund site, town of Londonderry, Rockingham County, New Hampshire: U.S. Environmental Protection Agency, September 2012, $103 \mathrm{p}$.

U.S. Geological Survey, 1950, Derry Quadrangle, New Hampshire-Rockingham Co., 7.5 Minute Series (TOPOGRAPHIC), 1:24,000 scale, 1 pl.

Welch, A.H., and Stollenwerk, K.G., eds., 2003, Arsenic in groundwater-Geochemistry and occurrence: Kluwer Academic Publishers, 2003, 475 p.
Weston Solutions, Inc., 2001, 2000 annual report, long-term environmental monitoring program at the Auburn road landfill site, Londonderry, New Hampshire: Weston Solutions, Inc., May 23, 2001, variously paged.

Weston Solutions, Inc., 2002, 2001 annual report, long-term environmental monitoring program at the Auburn road landfill site, Londonderry, New Hampshire: Weston Solutions, Inc., February 28, 2002, variously paginated.

Weston Solutions, Inc., 2003, 2002 annual report, long-term environmental monitoring program at the Auburn road landfill site, Londonderry, New Hampshire: Weston Solutions, Inc., April 22, 2003, variously paginated.

Weston Solutions, Inc., 2004, 2003 annual report, long-term environmental monitoring program at the Auburn road landfill site, Londonderry, New Hampshire: Weston Solutions, Inc., February 17, 2004, variously paginated.

Weston Solutions, Inc., 2005, 2004 annual report, long-term environmental monitoring program at the Auburn road landfill site, Londonderry, New Hampshire: Weston Solutions, Inc., February 17, 2005, variously paginated.

Weston Solutions, Inc., 2006, 2005 annual report, long-term environmental monitoring program at the Auburn road landfill site, Londonderry, New Hampshire: Weston Solutions, Inc., February 17, 2006, variously paginated.

Weston Solutions, Inc., 2007, 2006 annual report, long-term environmental monitoring program at the Auburn road landfill site, Londonderry, New Hampshire: Weston Solutions, Inc., March 2, variously paginated.

Weston Solutions, Inc., 2008, 2007 revised final annual report, long-term environmental monitoring program at the Auburn road landfill site, Londonderry, New Hampshire: Weston Solutions, Inc., May 30, 2008, variously paginated.

Weston Solutions, Inc., 2009, 2008 annual report, long-term environmental monitoring program Auburn Road Landfill site Londonderry, New Hampshire: Weston Solutions, Inc., variously paginated.

Weston Solutions, Inc., 2010, 2009 draft annual report, longterm environmental monitoring program at the Auburn road landfill site, Londonderry, New Hampshire: Weston Solutions, Inc., July 19, variously paginated.

Weston Solutions, Inc., 2011, 2010 draft annual report, longterm environmental monitoring program at the Auburn road landfill site, Londonderry, New Hampshire: Weston Solutions, Inc., July 19, variously paginated.

Weston Solutions, Inc., 2012, draft 2011 annual report longterm environmental monitoring program Auburn road landfill site, Londonderry, New Hampshire: Weston Solutions, Inc., March 19, 486 p. 
White, C.A., and Sevee, J.E., 1999, Arsenic mobilization mechanisms at a landfill site in southern New Hampshire and an evaluation of the effectiveness of remedial actions on dissolved arsenic concentrations: American Geophysical Union, Spring Meeting, June 1-4, 1999, Boston, Mass., abstract, $1 \mathrm{p}$.

Whitlock, I.A., and Kelly, T.M., 2010, Relationship between subsurface landfill gas and arsenic mobilization into groundwater: Ground Water Monitoring \& Remediation, v. 30, no. 2, spring, p. 86-96.

Won, I.J., Keiswetter, D.A., Fields, G.R.A., and Sutton, L.C., 1996, GEM-2-A new multifrequency electromagnetic sensor: Journal of Environmental and Engineering Geophysics, v. 1 , no. 2, p. 129-137.

Wovkulich, Karen, Mailloux B.J., Bostick, B.C., Dong, Hailiang, Bishop, M.E., and Chillrud S.N., 2012, Use of microfocused $\mathrm{x}$-ray techniques to investigate the mobilization of arsenic by oxalic acid: Geochimica et Cosmochimica Acta, v. 91, August 15, p. 254-270.

Wovkulich, Karen, Mailloux, B.J., Lacko, Allison, Keimowitz, A.R., Stute, Martin, Simpson, H.J., and Chillrud, S.N., 2010, Chemical treatments for mobilizing arsenic from contaminated aquifer solids to accelerate remediation: Applied Geochemistry, v. 25, October, p. 1500-1509.

Yu, Ran, Gan, Ping, MacKay, A.A., Shouliang, Zhang, and Smets, B.F., 2010, Presence, distribution, and diversity of iron-oxidizing bacteria at a landfill leachate-impacted groundwater surface water interface: FEMS Microbiology Ecology, v. 71, no. 2, p. 260-271, doi:10.1111/j.15746941.2009.00797.x.

Zohdy, A.A.R., Eaton, G.P., and Mabey, D.R., 1974, Application of surface geophysics to ground-water investigations: U.S. Geological Survey Techniques of Water-Resources Investigations, book 2, chap. D1, 86 p., accessed February 15, 2013, at http://pubs.usgs.gov/twri/twri2-d1/. 
THIS PAGE INTENTIONALLY LEFT BLANK 
Appendixes 1-7 
THIS PAGE INTENTIONALLY LEFT BLANK 


\section{Appendix 1. Summary of Results of Geophysical-Data Processing and Borehole Geophysical Log Analysis}

A total of about 9 miles of electromagnetic (EM) surveys, 16 line segments of ground-penetrating radar (GPR), 14 direct current (DC)-resistivity lines, and 23 borehole logs were completed at the site as part of this study. The Geophex GEM-2 Plus, a portable multifrequency electromagnetic sensor, was used for frequency-domain electromagnetic (FDEM) surveys in this study (Geophex, Ltd., 2007). Fifteen frequencies ranging from 2010 to 40,050 Hertz were chosen; lower frequencies were used to increase the depth of the subsurface materials investigated (Geophex, Ltd., 2007; Huang and Won, 2000; Won and others, 1996). Before and after each FDEM survey, one of three common base stations was measured to provide data for the linear correction of drift (shift in instrument response with time). Data collection and processing methods used in this study were similar to those used in Abraham and others (2006). The shifted data were calibrated to the same scale with the results of inverted DC-resistivity data. Total conductivity and inverted data (to provide interpretations with depth) were produced from the processed EM data by using WinGEM version 3, 0, 0, 14 (Geophex, Ltd., 2007).

Table 1-1. Root mean square error of direct-current resistivity inversion.

[Lines are shown on figure 1-1]

\begin{tabular}{ccc}
\hline Line identifier & Date & Root mean square error \\
\hline 1 & $1 / 31 / 2011$ & 5.6 \\
2 & $2 / 1 / 2011$ & 5 \\
3 & $2 / 3 / 2011$ & 10.3 \\
4.1 & $2 / 3 / 2011$ & 12.9 \\
4.2 & $2 / 3 / 2011$ & 5 \\
5.1 & $2 / 3 / 2011$ & 6.6 \\
7.1 & $2 / 9 / 2011$ & 4.1 \\
7.2 & $2 / 9 / 2011$ & 3.2 \\
8 & $7 / 25 / 2011$ & 23.8 \\
9 & $7 / 26 / 2011$ & 18.5 \\
10 & $7 / 27 / 2011$ & 22.8 \\
11 & $7 / 27 / 2011$ & 4.2 \\
12 & $7 / 28 / 2011$ & 31 \\
13 & $7 / 29 / 2011$ & 15.2 \\
\hline
\end{tabular}

DC-resistivity-array types included dipole-dipole and Schlumberger arrays (Zohdy and others, 1974). Reverse dipole-dipole and reciprocal Schlumberger surveys served as quality-check surveys for this study. Results provided by the dipole-dipole array have the greatest lateral resolution but the lowest signal-to-noise ratio. Some data points were removed because of large errors in the data generated in some of the driest parts of the survey lines, where current application was difficult. Reverse and forward dipole-dipole survey data that were combined and inverted together five times are interpreted and presented in this report. Root mean square error from the inversions is a measure of quality and provided a means to assess the model match to the field data (apparent resistivity) (table 1-1). DC-resistivity data were processed (inverted) by using RES2DINV version 3.55 (Loke, 1999) to provide estimates of resistivity at specific depths. The smaller number of data points at the ends of the survey lines made results for the line ends slightly less reliable. The quality-check (reverse) survey results were compared to results from the other surveys to ensure that the same general patterns and interpretations would be made.

As part of this study, new borehole geophysical logs were collected in August 2011 in 22 polyvinyl-chloride-cased wells (already installed in up to 60 feet $(\mathrm{ft}$ ) of unconsolidated sand and gravel). One deep (210-ft) borehole in bedrock with a steel casing also was logged (NUS-3). All results are given in feet below top of casing. Logs collected include natural gamma radiation, EM induction, and neutron porosity. Hydraulic conductivities measured by slug tests in groundwater were available from 17 wells (Sevee and Maher Engineering, 1992); 8 of these wells were logged, or an adjacent well was logged, as part of this study. A total of 33 wells were logged, or an adjacent well was logged, in 13 locations, 2 of which had 3 adjacent wells (table 1-2). Hydraulic conductivity values within the glacial-sediment aquifer ranged from 0.074 to $140 \mathrm{ft}$ per day. Geophysical-logging results were compared to geologic $\operatorname{logs}$ and water-quality results for analysis. Specific conductance data obtained from groundwater within specific screened intervals of monitoring wells were summarized to assess EM logs.

Acoustic televiewer (ATV) logs, which provide images of the borehole wall, were collected in a bedrock well at this site in 1985 as a part of a previous investigation of superfund sites (Bruce Hanson, formerly of the U.S. Geological Survey, written commun., 1985). The ATV log was interpreted in concert with EM and gamma logs. The methods of collection and analysis of ATV logs are described by Johnson and others (2005). 


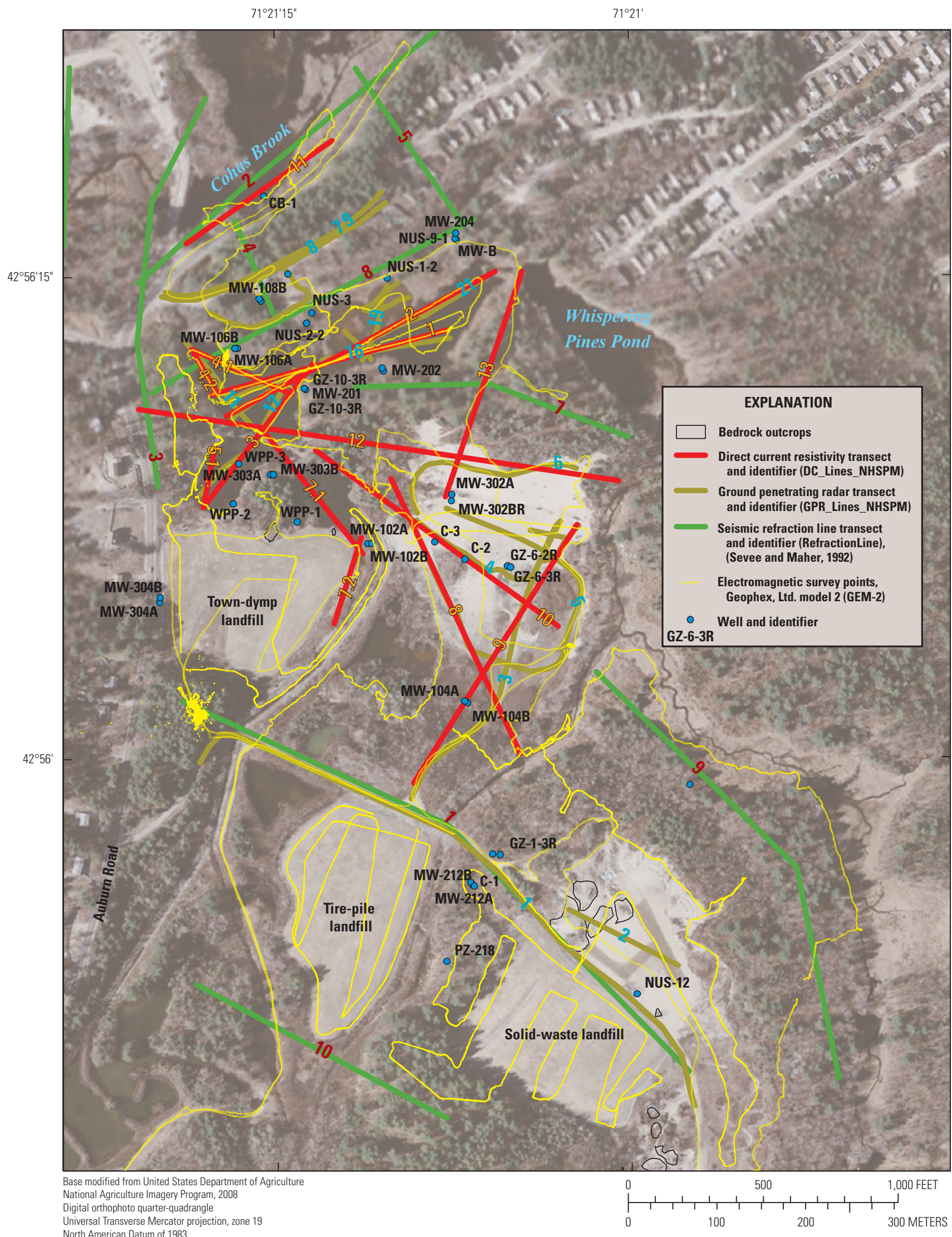

Figure 1-1. The locations of additional wells, outcrops, and geophysical surveys not specifically named elsewhere in this report, Auburn Road Landfill Superfund Site, Londonderry, New Hampshire. 
Table 1-2. Summary of borehole geophysical measurements at screened intervals, August 2011, Auburn Road Landfill Site, Londonderry, New Hampshire.

[Data in red are estimated screen intervals. EM, electromagnetic; K, hydraulic conductivity in feet per day (Sevee and Maher, 1992, 1993b); SC, specific conductance in microsiemens per square centimeter per day at 25 degrees Celsius]

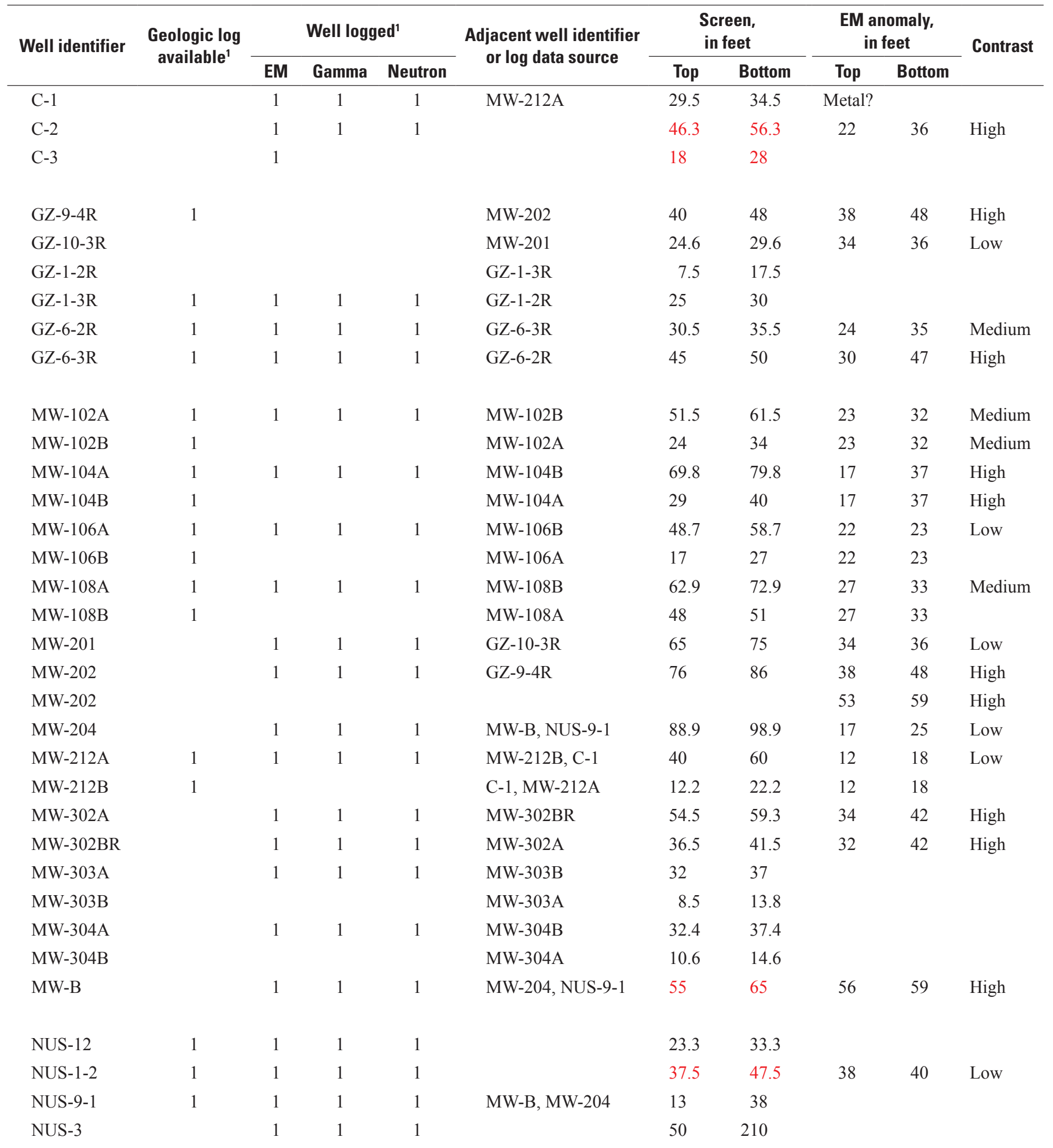


Table 1-2. Summary of borehole geophysical measurements at screened intervals, August 2011, Auburn Road Landfill Site, Londonderry, New Hampshire.-Continued

[Data in red are estimated screen intervals. EM, electromagnetic; K, hydraulic conductivity in feet per day (Sevee and Maher, 1992, 1993b); SC, specific conductance in microsiemens per square centimeter per day at 25 degrees Celsius]

\begin{tabular}{|c|c|c|c|c|c|c|c|c|c|c|}
\hline \multirow{2}{*}{$\begin{array}{c}\text { Well } \\
\text { identifier }\end{array}$} & \multirow{2}{*}{$\begin{array}{l}\text { Well log } \\
\text { inferred }^{2}\end{array}$} & \multirow{2}{*}{$\begin{array}{c}\text { Overburden } \\
K \text {, } \\
\text { in feet } \\
\text { per day }\end{array}$} & \multirow{2}{*}{$\begin{array}{c}\text { Bedrock } \\
K \text {, } \\
\text { in feet } \\
\text { per day }\end{array}$} & \multirow{2}{*}{$\begin{array}{l}\text { Type of } \\
\text { geologic } \\
\text { material }\end{array}$} & \multicolumn{3}{|c|}{ Average over screen interval } & \multirow{2}{*}{$\begin{array}{c}\text { SC } \\
\text { spring } \\
2011\end{array}$} & \multirow{2}{*}{$\begin{array}{c}S C \\
\text { fall } \\
2011\end{array}$} & \multirow{2}{*}{$\begin{array}{l}\text { SC } \\
\text { fall } \\
2010\end{array}$} \\
\hline & & & & & EM & Gamma & Neutron & & & \\
\hline $\mathrm{C}-2$ & & & & Bedrock & 10.1 & 108.1 & 2,605 & & & \\
\hline $\mathrm{C}-3$ & & & & Overburden & 15.2 & Blocked & Blocked & & & \\
\hline GZ-9-4R & & 62 & & Overburden & & & & & & \\
\hline GZ-10-3R & 1 & 45 & & Overburden & 14.7 & 111.8 & 991 & & & \\
\hline GZ-1-2R & 1 & & & Overburden & 13.7 & 108.7 & 851 & 343 & 286 & 392 \\
\hline GZ-1-3R & & & 0.43 & Bedrock & 9.1 & 213.7 & 4,761 & 372 & 322 & 363 \\
\hline GZ-6-2R & 1 & 27 & & Overburden & 20.2 & 75.8 & 517 & 207 & 298 & 205 \\
\hline MW-102B & 1 & 140 & & Overburden & 15.5 & 81.7 & 751 & & & \\
\hline MW-104A & & & 0.028 & Bedrock & 9.9 & 91.2 & 3,187 & & & \\
\hline MW-104B & 1 & 0.074 & & Overburden & 18.6 & 95.5 & 1,010 & 316 & 409 & 391 \\
\hline MW-106A & & & 0.1 & Bedrock & 11.4 & 357.3 & 4,111 & & & 353 \\
\hline MW-106B & 1 & 1.1 & & Overburden & 15.8 & 143.5 & 907 & & & 255 \\
\hline MW-108A & & & 0.034 & Bedrock & 12.9 & 193.2 & 3,441 & & & 414 \\
\hline MW-108B & 1 & 140 & & Overburden & 14 & 201.5 & 1,278 & & & 258 \\
\hline MW-201 & & & 0.012 & Bedrock & 16.4 & 245.2 & 3,363 & & & \\
\hline MW-302BR & & & & Overburden & 15.1 & 72.1 & 1,017 & 224 & 362 & 407 \\
\hline MW-303A & & & & Bedrock & 13.3 & 79.6 & 3,485 & 225 & 271 & 218 \\
\hline MW-303B & 1 & & & Overburden & 15.6 & 72.9 & 1,004 & 322 & 423 & 401 \\
\hline MW-304A & & & & Bedrock & 9.6 & 87.1 & 5,390 & & & \\
\hline MW-304B & 1 & & & Overburden & Metal casing & 146 & 869.6 & & & \\
\hline MW-B & & & & Bedrock & 16 & 113 & 1,430 & & & \\
\hline NUS-12 & & & & Bedrock & 7.9 & Blocked & Blocked & & & \\
\hline NUS-1-2 & & & & Overburden & 15.5 & 92.9 & 1,114 & & & \\
\hline NUS-9-1 & 1 & & & Overburden & 12.5 & 74.6 & 837 & & & 226 \\
\hline NUS-3 & & & & Bedrock & 10.8 & 249 & 3,404 & & & \\
\hline
\end{tabular}

${ }^{1}$ Where " 1 " is shown, logs are available. Blank cells indicate no logs are available.

${ }^{2}$ For wells where no logs are available, logs are inferred from adjacent well (indicated with " 1 " in column). In addition, for certain wells with logs, logs are also inferred from adjacent wells (also indicated with "1"). 


\section{References Cited}

Abraham, Jared, Deszcz-Pan, Maria, Fitterman, David, and Burton, Bethany, 2006, Use of a handheld broadband FDEM induction system for deriving resistivity depth images, in Symposium on the Application of Geophysics to Engineering and Environmental Problems, 19, Las Vegas, Nevada, February 10-14, 2002, Proceedings: Denver, Colo., Environmental and Engineering Geophysical Society CD-ROM, p. 1782-1799.

Geophex, Ltd., 2007, DEM-2 broadband EMI sensor: Geophex, Ltd., accessed June 14, 2011, at http://www. geophex.com/GEM_2\%20Handheld.html.

Huang, Haoping, and Won, I.J., 2000, Conductivity and susceptibility mapping using broadband electromagnetic sensors: Journal of Environmental and Engineering Geophysics, v. 5 , no. 4 , p. 31-41.

Johnson, C.D., Joesten, P.K., and Mondazzi, R.A., 2005, Borehole-geophysical and hydraulic investigation of the fractured-rock aquifer near the University of Connecticut landfill, Storrs, Connecticut, 2000 to 2001: U.S. Geological Survey Water-Resources Investigations Report 03-4125, $133 \mathrm{p}$.

Loke, M.H., 1999, Electrical imaging surveys for environmental and engineering studies-A practical guide to 2-D and 3-D surveys: Stanford University, School of Earth Sciences, $57 \mathrm{p}$., accessed October 2, 2009, at http://www.agiusa. com/literature.shtml. (Also accessed February 15, 2013, at https://pangea.stanford.edu/research/groups/sfmf/docs/ DCResistivity_Notes2.pdf.)

Sevee and Maher Engineering, 1992, Pre-design investigation report for remediation of groundwater, Auburn road landfill site: Londonderry, N.H., Sevee and Maher Engineering, 2 vols.

U.S. Geological Survey, variously dated, National field manual for the collection of water-quality data: U.S. Geological Survey Techniques of Water-Resources Investigations, book 9, chaps. A1-A9, accessed May 30, 2013, at http://pubs.water.usgs.gov/twri9A.

Won, I.J., Keiswetter, D.A., Fields, G.R.A., and Sutton, L.C., 1996, GEM-2 - A new multifrequency electromagnetic sensor: Journal of Environmental and Engineering Geophysics, v. 1 , no. 2, p. 129-137.

Zohdy, A.A.R., Eaton, G.P., and Mabey, D.R., 1974, Application of surface geophysics to ground-water investigations: U.S. Geological Survey Techniques of Water-Resources Investigations, book 2, chap. D1, 86 p., accessed February 15,2013 , at http://pubs.usgs.gov/twri/twri2-d1/. 
THIS PAGE INTENTIONALLY LEFT BLANK 


\section{Appendix 2. Three-Dimensional Diagram Showing Locations of Wells, Bedrock-Surface Altitudes from Seismic Refraction Surveys, and Results from Electromagnetic and Direct-Current Resistivity Geophysical Surveys}

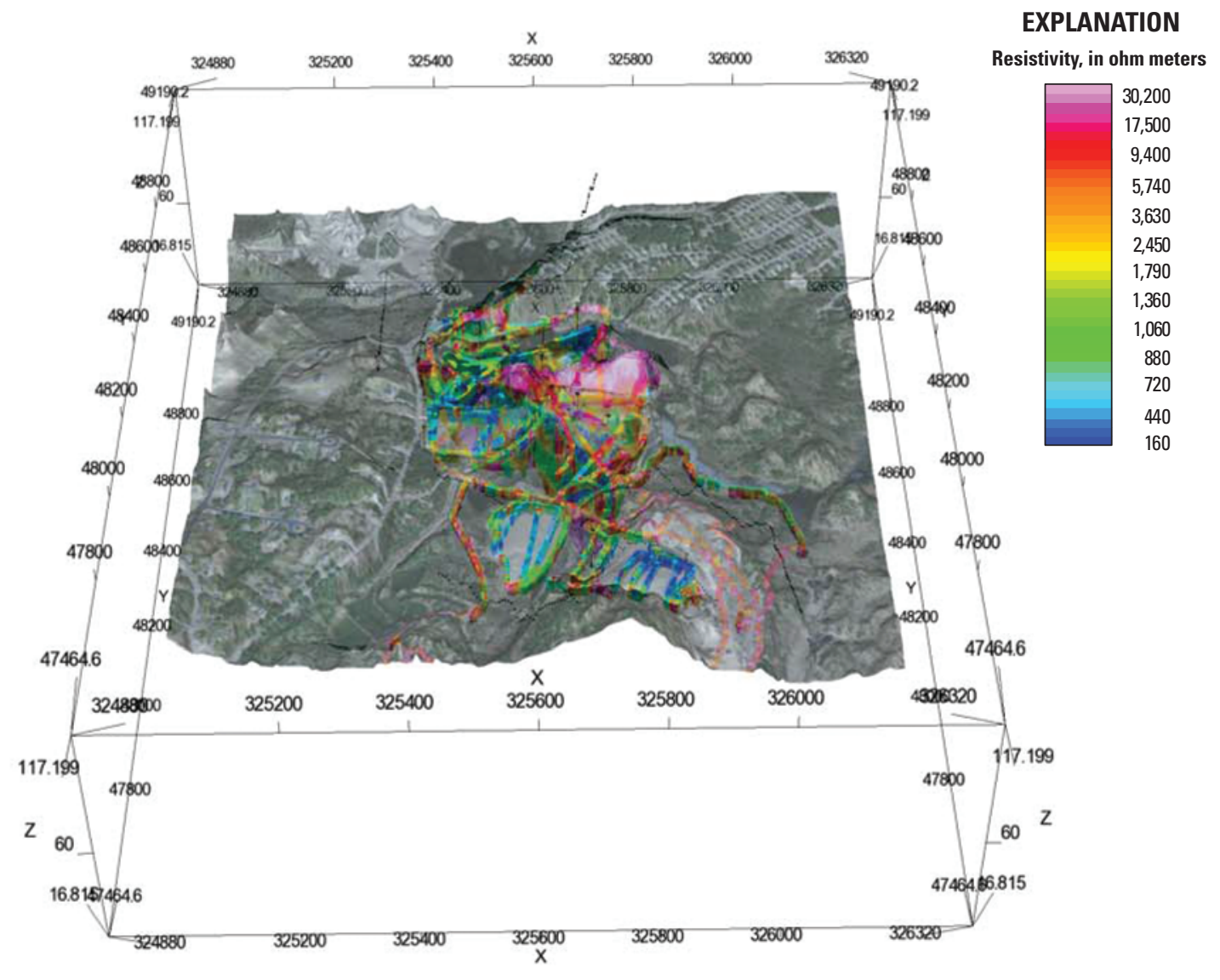

This is a proxy image of a user-interactive portable document format file (PDF). You must download and then open the file with Acrobat Pro or Acrobat Reader. Free PDF-reading software is available at http://get.adobe.com/reader/ To get the user-interactive PDF, click here or select from the web-page menu. 
THIS PAGE INTENTIONALLY LEFT BLANK 


\section{Appendix 3. Preliminary Bedrock-Surface Map}




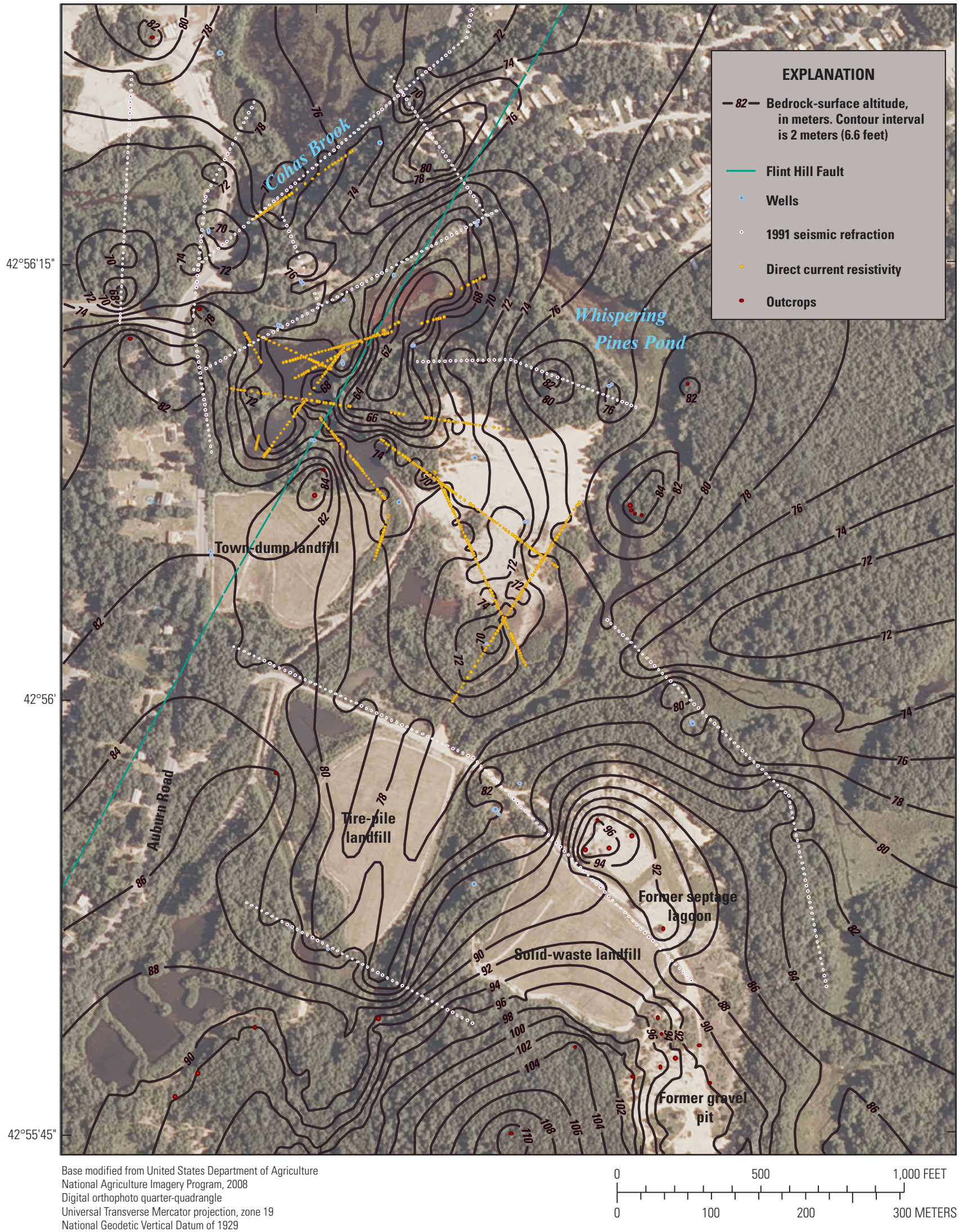

Figure 3-1. Bedrock-surface altitudes, outcrops, and seismic refraction and direct-current resistivity survey lines, Auburn Road Landfill Superfund Site, Londonderry, New Hampshire. 


\section{Appendix 4. Geochemical Data Used for Redox-Zone Classification, Spring 2008}

Table 4-1. Geochemical data used for redox-zone classification, spring 2008.

[Numbers in boldface in the first line of the table are threshold values. Wells shown on figure 1-1. Concentrations given as 0 were below the detection limit. $\mathrm{mg} / \mathrm{L}$, milligrams per liter; $\mu \mathrm{g} / \mathrm{L}$, micrograms per liter; $\mathrm{O}_{2}$, oxygen reduction; $\mathrm{Fe}(\mathrm{III})$, iron reduction; $\mathrm{SO}_{4}$, $\mathrm{sulfate}$ reduction; $\mathrm{CH}_{4}$, methanogenesis; $\mathrm{Mn}_{\text {, manga- }}$ nese reduction; $\mathrm{NO}_{3}$, nitrate reduction]

\begin{tabular}{|c|c|c|c|c|c|c|c|c|c|}
\hline Well identifier & $\begin{array}{c}\text { Redox } \\
\text { variables }\end{array}$ & $\begin{array}{l}\text { Dissolved } \\
\text { oxygen, } \\
\text { in } \mathrm{mg} / \mathrm{L}\end{array}$ & $\begin{array}{c}\text { Nitrate } \\
\text { (as nitrogen), } \\
\text { in } \mathrm{mg} / \mathrm{L}\end{array}$ & $\begin{array}{c}\text { Manganese, } \\
\text { in } \mu \mathrm{g} / \mathrm{L}\end{array}$ & $\begin{array}{l}\text { Iron, } \\
\text { in } \mu g / L\end{array}$ & $\begin{array}{l}\text { Sulfate, } \\
\text { in } \mathrm{mg} / \mathrm{L}\end{array}$ & $\begin{array}{l}\text { General redox } \\
\text { category }\end{array}$ & Redox process & $\begin{array}{c}\text { Arsenic, } \\
\text { in } \mu \mathrm{g} / \mathrm{L}\end{array}$ \\
\hline & & 1 & 0.5 & 50 & 100 & 0.5 & & & \\
\hline A-31 & & 6.54 & 0.26 & 94.6 & 8,810 & 7.6 & Mixed & $\mathrm{O}_{2}-\mathrm{Fe}(\mathrm{III}) / \mathrm{SO}_{4}$ & 0 \\
\hline A-33 & & 0.23 & 0.22 & 1,610 & 25,300 & 6.5 & Anoxic & $\mathrm{Fe}(\mathrm{III}) / \mathrm{SO}_{4}$ & 68 \\
\hline A-46 & & 9.65 & 0 & 0 & 0 & 0 & Oxic & $\mathrm{O}_{2}$ & 0 \\
\hline $\mathrm{C}-1$ & & 0.28 & 0 & 3,560 & 48,900 & 0 & Anoxic & $\mathrm{CH}_{4}$ & 236 \\
\hline GZ-10-3R & & 0.31 & 0.19 & 3,550 & 4,050 & 10.6 & Anoxic & $\mathrm{Fe}(\mathrm{III}) / \mathrm{SO}_{4}$ & 16.8 \\
\hline GZ-1-2 & & 0.63 & 0 & 3,990 & 34,600 & 0 & Anoxic & $\mathrm{CH}_{4}$ & 33.9 \\
\hline GZ-1-3R & & 0.38 & 0.09 & 481 & 4,930 & 0 & Anoxic & $\mathrm{CH}_{4}$ & 28.7 \\
\hline GZ-6-2R & & 0.25 & 0.16 & 3,440 & 26,600 & 0 & Anoxic & $\mathrm{CH}_{4}$ & 205 \\
\hline GZ-6-3R & & 0.58 & 0.16 & 5,590 & 37,600 & 5.5 & Anoxic & $\mathrm{Fe}(\mathrm{III}) / \mathrm{SO}_{4}$ & 169 \\
\hline GZ-9-4R & & 2.04 & 0.28 & 4,300 & 29,500 & 6.6 & Mixed & $\mathrm{O}_{2}-\mathrm{Fe}(\mathrm{III}) / \mathrm{SO}_{4}$ & 54.6 \\
\hline MW-102A & & 3.33 & 0.12 & 0 & 0 & 14.7 & Oxic & $\mathrm{O}_{2}$ & 0 \\
\hline MW-102B & & 0.38 & 0 & 4,820 & 15,700 & 11.6 & Anoxic & $\mathrm{Fe}(\mathrm{III}) / \mathrm{SO}_{4}$ & 49.8 \\
\hline MW-104B & & 1.48 & 0.18 & 2,960 & 51,800 & 0 & Mixed & $\mathrm{O}_{2}-\mathrm{CH}_{4}$ & 115 \\
\hline MW-106A & & 7.03 & 0 & 93.8 & 0 & 12.9 & Mixed & $\mathrm{O}_{2}-\mathrm{Mn}(\mathrm{IV})$ & 0 \\
\hline MW-106B & & 1.42 & 0.46 & 2,560 & 5,850 & 23.1 & Mixed & $\mathrm{O}_{2}-\mathrm{Fe}(\mathrm{III}) / \mathrm{SO}_{4}$ & 0 \\
\hline MW-108A & & 2.44 & 0 & 0 & 0 & 17.4 & Oxic & $\mathrm{O}_{2}$ & 0 \\
\hline MW-108B & & 0.4 & 0 & 3,660 & 1,890 & 15.7 & Anoxic & $\mathrm{Fe}(\mathrm{III}) / \mathrm{SO}_{4}$ & 0 \\
\hline MW-109A & & 0.7 & 0 & 0 & 151 & 13.2 & Anoxic & $\mathrm{Fe}(\mathrm{III}) / \mathrm{SO}_{4}$ & 0 \\
\hline MW-109B & & 7.14 & 6.3 & 15.8 & 0 & 6.9 & Oxic & $\mathrm{O}_{2}$ & 0 \\
\hline MW-201 & & 2.23 & 0 & 174 & 101 & 16.3 & Mixed & $\mathrm{O}_{2}-\mathrm{Fe}(\mathrm{III}) / \mathrm{SO}_{4}$ & 0 \\
\hline MW-202 & & 7.73 & 0.36 & 933 & 5,660 & 0 & Mixed & $\mathrm{O}_{2}-\mathrm{CH}_{4}$ & 0 \\
\hline MW-204 & & 9.67 & 1.7 & 0 & 0 & 11.3 & Oxic & $\mathrm{O}_{2}$ & 0 \\
\hline MW-301A & & 4.29 & 0 & 0 & 0 & 14.8 & Oxic & $\mathrm{O}_{2}$ & 14.7 \\
\hline MW-302A & & 0.52 & 0.23 & 4,920 & 4,550 & 0 & Anoxic & $\mathrm{CH}_{4}$ & 20 \\
\hline MW-302B & & 0.59 & 1.8 & 669 & 361 & 11 & Mixed (anoxic) & $\mathrm{NO}_{3}-\mathrm{Fe}(\mathrm{III}) / \mathrm{SO}_{4}$ & 0 \\
\hline MW-303A & & 0.8 & 0 & 33.5 & 0 & 9.4 & Suboxic & Suboxic & 0 \\
\hline MW-303B & & 0.5 & 0.2 & 3,450 & 23,100 & 10.8 & Anoxic & $\mathrm{Fe}(\mathrm{III}) / \mathrm{SO}_{4}$ & 24.1 \\
\hline MW-304A & & 5.91 & 0 & 0 & 0 & 16.2 & Oxic & $\mathrm{O}_{2}$ & 0 \\
\hline MW-304B & & 5.58 & 2.9 & 0 & 0 & 15.7 & Oxic & $\mathrm{O}_{2}$ & 0 \\
\hline NUS-1-2 & & 1.31 & 0.22 & 4,040 & 23,800 & 10.6 & Mixed & $\mathrm{O}_{2}-\mathrm{Fe}(\mathrm{III}) / \mathrm{SO}_{4}$ & 206 \\
\hline NUS-2-2 & & 0.6 & 0.18 & 1,870 & 11,400 & 9 & Anoxic & $\mathrm{Fe}(\mathrm{III}) / \mathrm{SO}_{4}$ & 99.2 \\
\hline NUS-9-1 & & 9.4 & 4.2 & 0 & 0 & 8.3 & Oxic & $\mathrm{O}_{2}$ & 0 \\
\hline PZ-218 & & 0.24 & 0.22 & 4,810 & 36,800 & 6 & Anoxic & $\mathrm{Fe}(\mathrm{III}) / \mathrm{SO}_{4}$ & 363 \\
\hline
\end{tabular}


THIS PAGE INTENTIONALLY LEFT BLANK 
Appendix 5. Preliminary Spatial Distribution of Redox Zones, Water Table, and Flow Directions in the Glacial-Sediment Aquifer, Spring 2008 


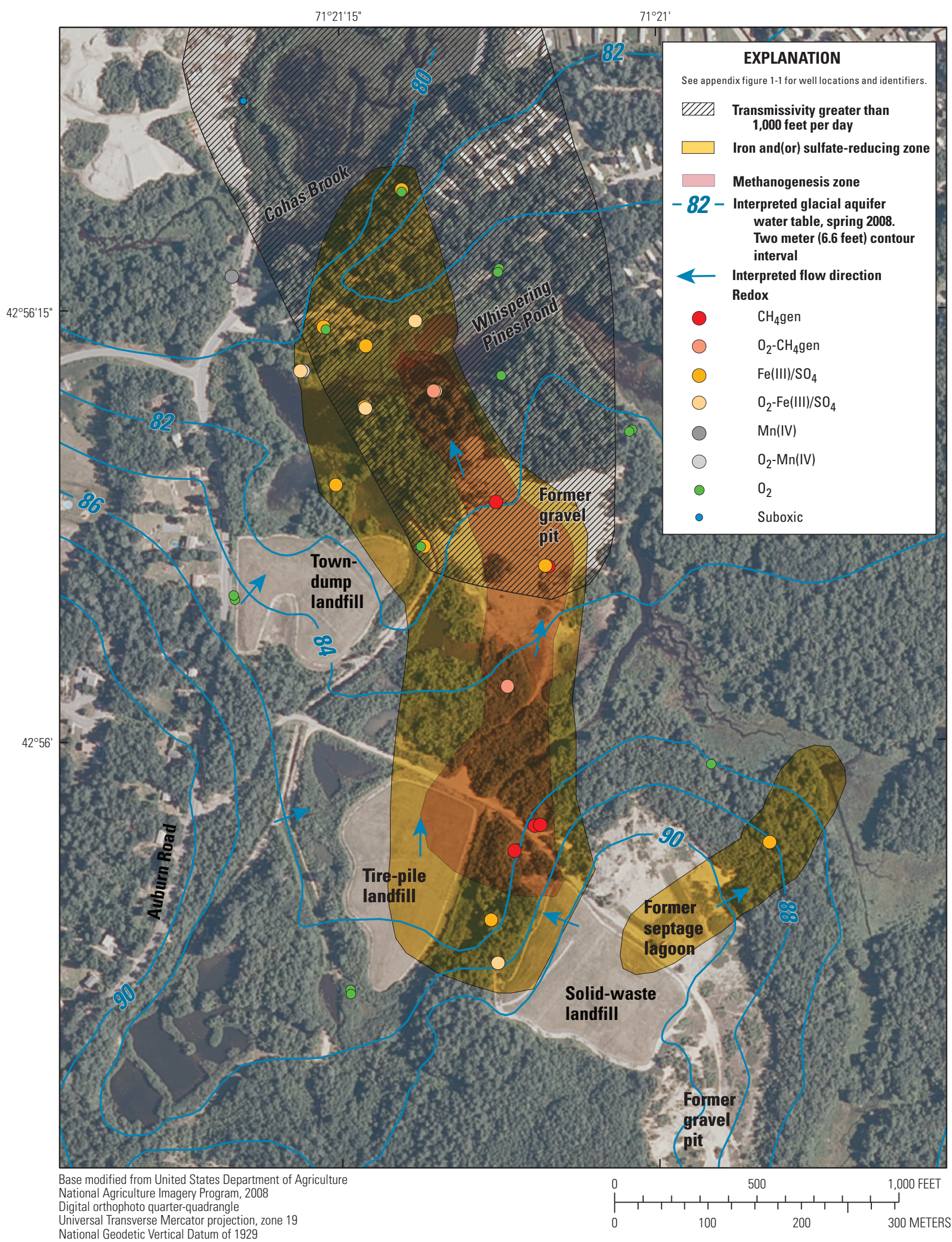

Figure 5-1. Preliminary spatial distribution of redox zones, water table, and flow directions in the glacial-sediment aquifer, spring 2008. 
Table 5-1. Estimated saturated thickness of wastes and altitudes of the waste and water table, spring 2008.

[Altitude of bottom of waste from Sevee and Maher, 1993, figure 4-1. Estimate of altitude of spring 2008 preliminary potentiometric surface shown on the map in appendix 3 . Vertical coordinate information is referenced to the National Geodetic Vertical Datum of 1929 (NGVD of 1929). Altitude, as used in this report, refers to distance above the vertical datum]

\begin{tabular}{|c|c|c|c|}
\hline \multirow{2}{*}{$\begin{array}{l}\text { Piezometer } \\
\text { identifier }\end{array}$} & \multicolumn{2}{|c|}{$\begin{array}{l}\text { Altitude, } \\
\text { in feet }\end{array}$} & \multirow{2}{*}{$\begin{array}{c}\text { Thickness of } \\
\text { saturated waste, } \\
\text { in feet }\end{array}$} \\
\hline & Bottom of waste & $\begin{array}{l}\text { Estimate of spring } 2008 \\
\text { potentiometric surface }\end{array}$ & \\
\hline \multicolumn{4}{|c|}{ Landfill } \\
\hline \multicolumn{4}{|c|}{ Town dump } \\
\hline PZ-206 & ${ }^{1} 274.0$ & 270.0 & \\
\hline A-26 & 276.0 & 277.2 & 1.2 \\
\hline PZ-212 & ${ }^{1} 280.0$ & 280.2 & 0.2 \\
\hline A-29 & 274.5 & 272.0 & \\
\hline PZ-210 & ${ }^{1} 269.0$ & 269.0 & \\
\hline PZ-209 & 277.0 & 274.0 & \\
\hline \multirow[t]{2}{*}{ PZ-208 } & 276.0 & 275.6 & \\
\hline & ${ }^{2} 270.0$ & ${ }^{2} 275.0$ & 5.0 \\
\hline \multicolumn{4}{|c|}{ Tire pile } \\
\hline PZ-205 & 285.0 & 277.2 & \\
\hline PZ-213 & 287.0 & 277.2 & \\
\hline PZ-204 & 286.0 & 279.5 & \\
\hline PZ-203 & 279.5 & 284.1 & 4.6 \\
\hline A-15 & 282.0 & 279.5 & \\
\hline \multicolumn{4}{|c|}{ Solid waste landfill } \\
\hline PZ-214 & 303.0 & 300.9 & \\
\hline PZ-202 & 307.0 & 301.2 & \\
\hline PZ-207 & 307.0 & 298.9 & \\
\hline A-12 & 305.0 & 308.4 & 3.4 \\
\hline PZ-201 & NA & 302.8 & \\
\hline
\end{tabular}

'Altitude of bottom of waste from Weston, 2007.

${ }^{2}$ Altitude of bottom of waste and water table from Weston, 2009a. 
THIS PAGE INTENTIONALLY LEFT BLANK 


\section{Appendix 6. Reactive-Transport Model}

Concentrations of arsenic in groundwater at the Auburn Road Landfill Superfund Site were simulated by using the PHREEQC computer code (Parkhurst and Appelo, 1999). The general conditions tested and methods employed during the simulations are discussed in this appendix. Parameter sensitivity analysis is discussed in the main part of the report.

Simulation results show that most of the dissolved arsenic in groundwater at the site is in the arsenic (III) form. Dissolved arsenic (V) concentrations were typically much lower (three orders of magnitude or less) than concentrations of arsenic (III). Recent (2008) data collected at the site show appreciable (20 percent of total) concentrations of arsenic (V) in the groundwater in certain wells (Weston Solutions, 2008 and 2009), indicating the presence of a more complex dissolution process.

Simulated results are presented for dissolved arsenic (III) concentrations (table 6-1). Graphs of dissolved arsenic (III) concentrations show similar patterns along the onedimensional transport path regardless of the simulation, but the time required to flush the arsenic varies. Several simulations tested the effects of various initial conditions and parameter values on model results.

All simulations started with an initial increase in arsenic concentration caused by a disequilibrium state between the specified aqueous and surface concentrations (this effect could be reduced by use of a more complete geochemical dataset, including information on the amount of sorbed arsenic on aquifer sediments, from the site). Reducing the period of disequilibrium is desirable because initial conditions can affect the final results. An example showing concentration increases (reported as dimensionless concentrations) at the beginning of the simulation is shown in figure $6-1$. The initial starting arsenic (III) concentration increases by almost a factor of five before it declines to the initial concentration. This disequilibrium condition is partly caused by the uncertainty regarding the sorbed and aqueous concentrations, reaction rates, and mass of sorbed arsenic.

An initial reactive-transport model (base) was based on the assignment of likely parameter values and the objective of minimizing the early disequilibrium period. Groundwater transport was simulated through an iterative trial-and-error process. The initial static geochemistry representing leachateaffected groundwater was iteratively simulated as flowing through the aquifer for 10 to 20 years (called static geochemistry) prior to being flushed by clean water. The static geochemical conditions were then used as input to the model as the initial conditions for subsequent flushing simulations. The largest change from initial geochemical conditions was the decrease in $\mathrm{pE}$ (table 6-1). Redox potential expressed as $\mathrm{pE}$ is used widely in geochemical literature and is expressed as $\mathrm{pE}=\mathrm{Eh} / 0.0592$ when $\mathrm{Eh}$ is in volts $(\mathrm{Hem}, 1985)$. The disequilibrium period was also reduced by decreasing the number of surface-complexation sites by one-half of an order of magnitude overall and by one-quarter of the value from the simulation shown in figure 6-1. The initial estimate of the number of surface-complexation sites was based on data from the Saco landfill study in Maine (Stollenwerk and Colman, 2004). Concentrations during the initial simulations returned to their initial values after 25 percent of the simulation period had passed (fig. 6-1). In the base model, this duration was reduced to less than 10 percent.

Equations 6-1 through 6-5 describe the modeled surfacecomplexation reactions. Equilibrium constants (log k) are higher for arsenate (AsV) in equation (6-2) than arsenite (AsIII) in equation (6-1) because arsenite is more readily dissolved from surfaces.

$$
\begin{gathered}
\text { Surf_wOH }+\mathrm{H}_{3} \mathrm{AsO}_{3}=\text { Surf_w } \mathrm{wH}_{2} \mathrm{AsO}_{3}+\mathrm{H}_{2} \mathrm{O} \\
\log _{-} \mathrm{k} 5.41 \\
\text { Surf_wOH }+\mathrm{AsO}_{4}^{-3}+3 \mathrm{H}+=\mathrm{Surf}_{-} \mathrm{wH}_{2} \mathrm{AsO}_{4}+\mathrm{H}_{2} \mathrm{O} \\
\log _{-} \mathrm{k} 29.31 \\
\text { Surf_wOH }+\mathrm{AsO}_{4}^{-3}+2 \mathrm{H}+=\text { Surf_wHAsO }{ }_{4}^{-}+\mathrm{H}_{2} \mathrm{O} \\
\log _{-} \mathrm{k} 23.51 \\
\text { Surf_wOH }+\mathrm{AsO}_{4}^{-3}=\text { Surf_wOHAsO }{ }_{4}^{-3} \\
\log _{-} \mathrm{k} 10.58 \\
\text { SurfbOH }+ \text { Toc }=\text { SurfbOHToc } \\
\log \mathrm{k} 1.90
\end{gathered}
$$




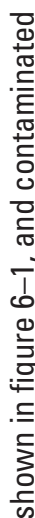

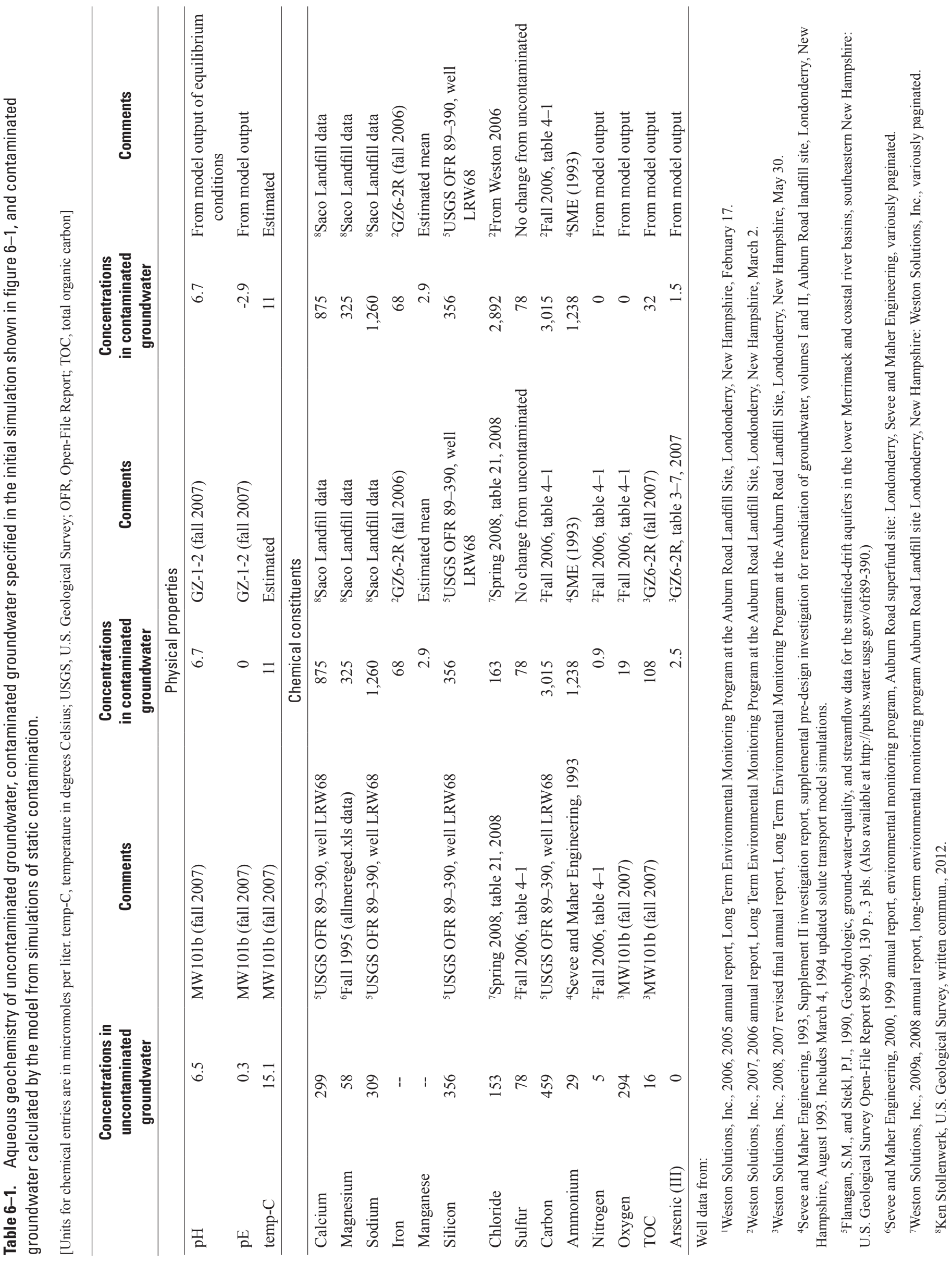




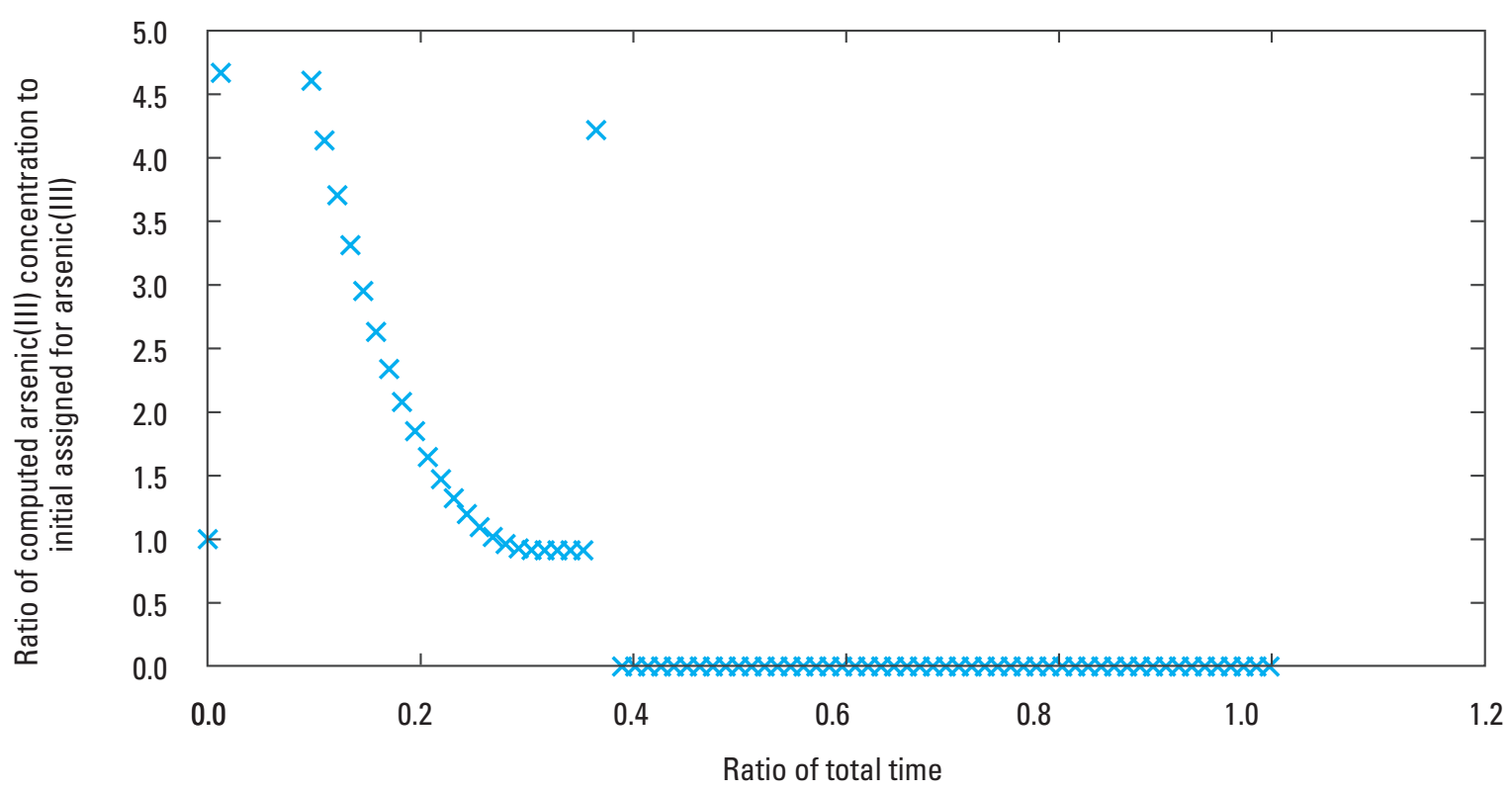

Figure 6-1. Decrease of the dimensionless arsenic concentration with time in a simulation by the reactive-transport model of the Auburn Landfill Superfund site, Londonderry, New Hampshire.

\section{References Cited}

Hem, J.D., 1985, Study and interpretation of the chemical characteristics of natural water ( $3 \mathrm{~d}$ ed.): U.S. Geological Survey Water-Supply Paper 2254, 263 p., 3 pls. (Reprinted in 1986 and 1989.) (Also available online at http://pubs. usgs.gov/wsp/wsp2254/.)

HydroQual, Inc., 2009, Results of model simulations predicted arsenic cleanup time at the Auburn Road landfill, Londonderry, New Hampshire: Mahwah, N.J., HydroQual, Inc., $69 \mathrm{p}$.

Parkhurst, D.L., and Appelo, C.A.J., 1999, User's guide to PHREEQC (version 2) - A computer program for speciation, batch-reaction, one-dimensional transport, and inverse geochemical calculations: U.S. Geological Survey WaterResources Investigations Report 99-4259, 312 p., accessed February 15, 2013, at http://pubs.usgs.gov/wri/1999/4259/ report.pdf.

Stollenwerk, K.G., and Colman, J.A., 2004, Natural remediation of arsenic contaminated ground water associated with landfill leachate: U.S. Geological Survey Fact Sheet 2004-6057, 4 p., accessed February 15, 2013, at http://pubs. usgs.gov/fs/2004/3057/.

Weston Solutions, Inc., 2009, 2008 annual report, long-term environmental monitoring program Auburn Road Landfill site Londonderry, New Hampshire: Weston Solutions, Inc., variously paginated. 
THIS PAGE INTENTIONALLY LEFT BLANK 


\section{Appendix 7. Piezometer Installation and Results of Analysis of Groundwater Samples, 2012}

Three minipiezometers were installed to determine groundwater heads, vertical gradients between the groundwater and surface water, and the quality of groundwater beneath discharge points to surface water. All piezometers show upward gradients, which are indicative of groundwater discharging to surface water. Wells WPP-1, WPP-2, and CB-1 were installed where iron oxide was observed on the bottom sediment. A fourth piezometer (WPP-3) targeted a conductive anomaly (possible leachate) as identified in surface geophysical surveys. The final depth of WPP-3 fell short of the anomaly because of a subsurface feature that obstructed penetration.

\section{Results}

Data from Table 7-1 indicate that

- Deuterium-oxygen-18 data indicate that sampled water represents primarily groundwater with little surfacewater recharge.

- Concentrations of methane correlated with those of arsenic. This correlation is a good indicator of reductive dissolution (Harte and others, 2012).

- Higher $\mathrm{CO}_{2}$ concentrations at WPP-2 with lower calculated recharge temperatures indicate that the sampled water was mixed from shallower and deeper flow paths.

- Isotopically heavier inorganic carbon-13 corresponds to arsenic detections, indicating groundwater that is derived from deeper flow paths.

\section{Reference Cited}

Harte, P.T., Ayotte, J.D., Hoffman, Andrew, Révész, K.M., Belaval, Marcel, Lamb, Steven, and Böhlke, J.K., 2012, Heterogeneous redox conditions, arsenic mobility, and groundwater flow in a fractured-rock aquifer near a waste repository site in New Hampshire, USA: Hydrogeology Journal, v. 20, no. 6, p. 1189-1201, accessed February 15, 2013, at http://ink.springer.com/article/10.1007\% 2Fs10040-012-0844-4. 
Table 7-1. Laboratory analysis of groundwater samples from piezometers installed in 2012.

[All concentrations are given in milligrams per liter $(\mathrm{mg} / \mathrm{L})$ except for recharge temperature and delta notation. Recharge temperature is given in degrees Celsius $\left({ }^{\circ} \mathrm{C}\right)$; shaded recharge temperatures indicate estimates; repeated rows are duplicate samples; WPP-1DUP is a duplicate quality control sample taken from piezometer WPP-1; ND, not detected; $\mathrm{CH}_{4}$, methane dissolved; $\mathrm{CO}_{2}$, carbon dioxide dissolved; $\mathrm{N}_{2}$, nitrogen dissolved; $\mathrm{O}_{2}$, oxygen dissolved; Ar, argon dissolved; $\delta$, ratio of the isotope in the sample to a known standard; ${ }^{15} \mathrm{~N}$, nitrogen isotope; ${ }^{18} \mathrm{O}$, oxygen isotope; ${ }^{13} \mathrm{C}$, carbon isotope; \%o, Per mil (parts per thousand)]

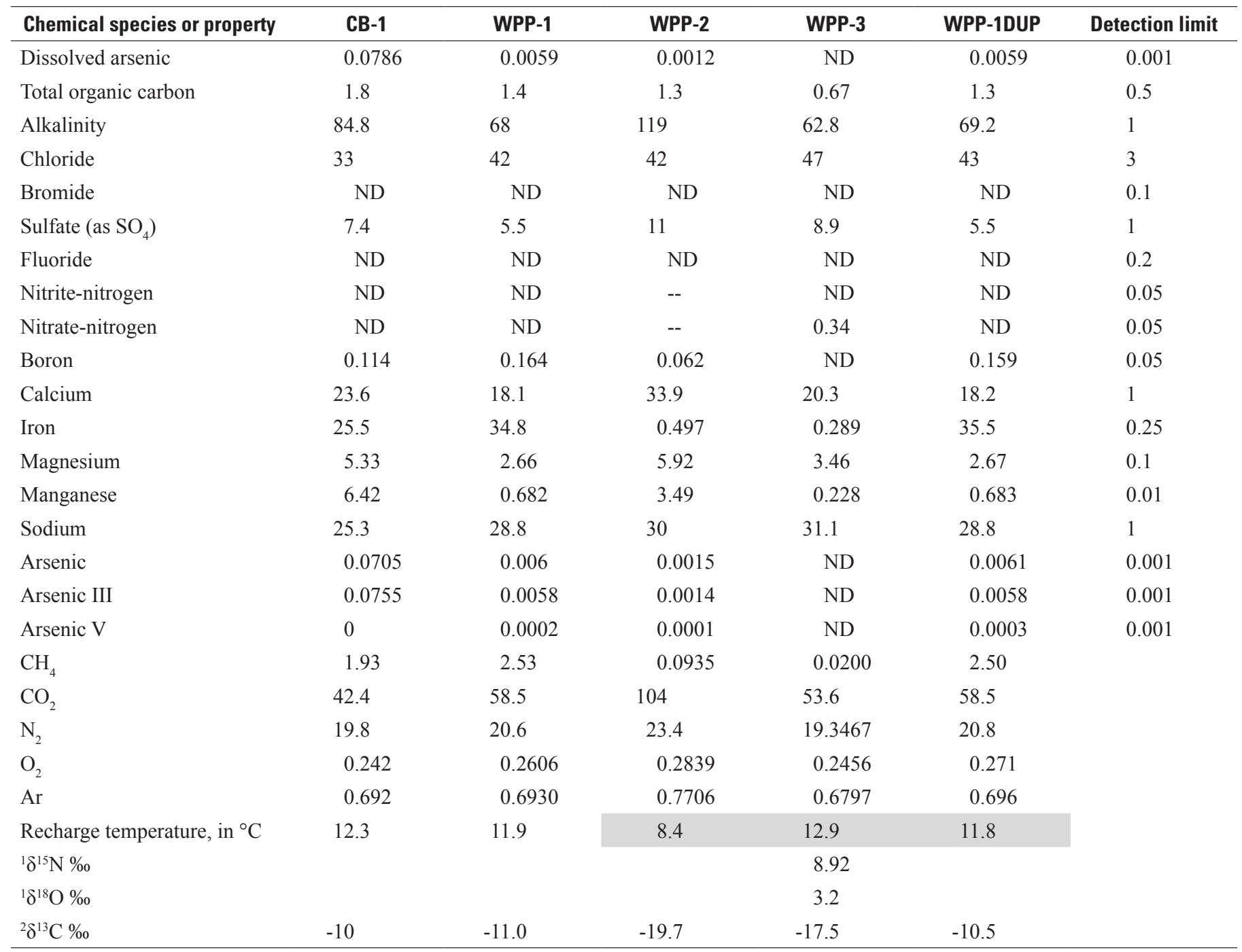

${ }^{1}$ From nitrate.

${ }^{2}$ From dissolved inorganic carbon.

${ }^{3}$ From dissolved organic carbon. 


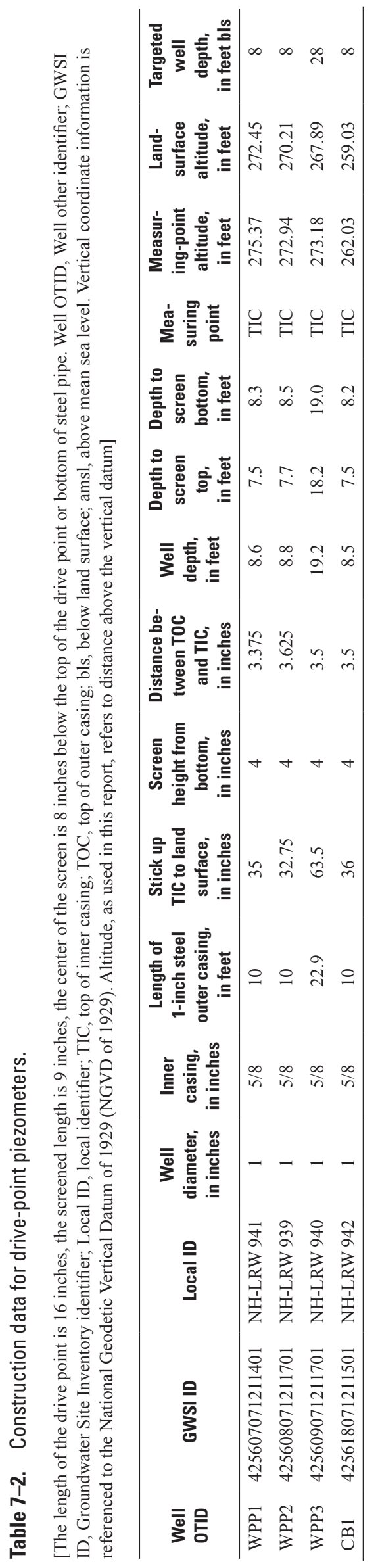


Table 7-3. Water-quality parameters for groundwater samples collected from piezometers installed in 2012.

[NTU, nephelometric turbidity units; DTW, depth to water, in feet; MP, measuring point; LS, land surface]

\begin{tabular}{|c|c|c|c|c|c|}
\hline Well identifier & CB-1 & WPP-1 & WPP-2 & WPP-3 & Units \\
\hline Specific conductance & 311 & 389 & 372 & 309 & Microsiemens per centimeter \\
\hline Temperature & 14.7 & 12.1 & 12.2 & 13.7 & Degrees Celsius \\
\hline Dissolved oxygen ${ }^{1}$ & 1.2 & 0.4 & 0.8 & 0.8 & Milligrams per liter \\
\hline Dissolved oxygen ${ }^{2}$ & 0.1 & 0.1 & 0.1 & 0.2 & Milligrams per liter \\
\hline $\mathrm{pH}$ & 6.2 & 6.3 & 6.1 & 6.3 & \\
\hline Turbidity & 298 & 22 & 0.43 & 4 & NTU \\
\hline Ferrous iron ${ }^{3}$ & 3.2 & 4.2 & 0.9 & 0.5 & Micrograms per liter \\
\hline Ferrous iron ${ }^{2}$ & & & 0.7 & & Micrograms per liter \\
\hline DTW in well & 3.63 & 2.95 & 2.92 & 3.51 & Feet \\
\hline DTW outside well & & & & 3.98 & Feet \\
\hline MP stick up from LS & 3.89 & 3 & 3.08 & & Feet \\
\hline
\end{tabular}

${ }^{1}$ Measured in flow through cell.

${ }^{2}$ Measured by colormetric analysis.

${ }^{3}$ Measured by photometric analysis. 
Prepared by the Pembroke Publishing Service Center.

For more information concerning this report, contact:

Office Chief

U.S. Geological Survey

New England Water Science Center

New Hampshire-Vermont Office

331 Commerce Way, Suite 2

Pembroke, NH 03275

dc_nh@usgs.gov

or visit our Web site at:

http://nh.water.usgs.gov 


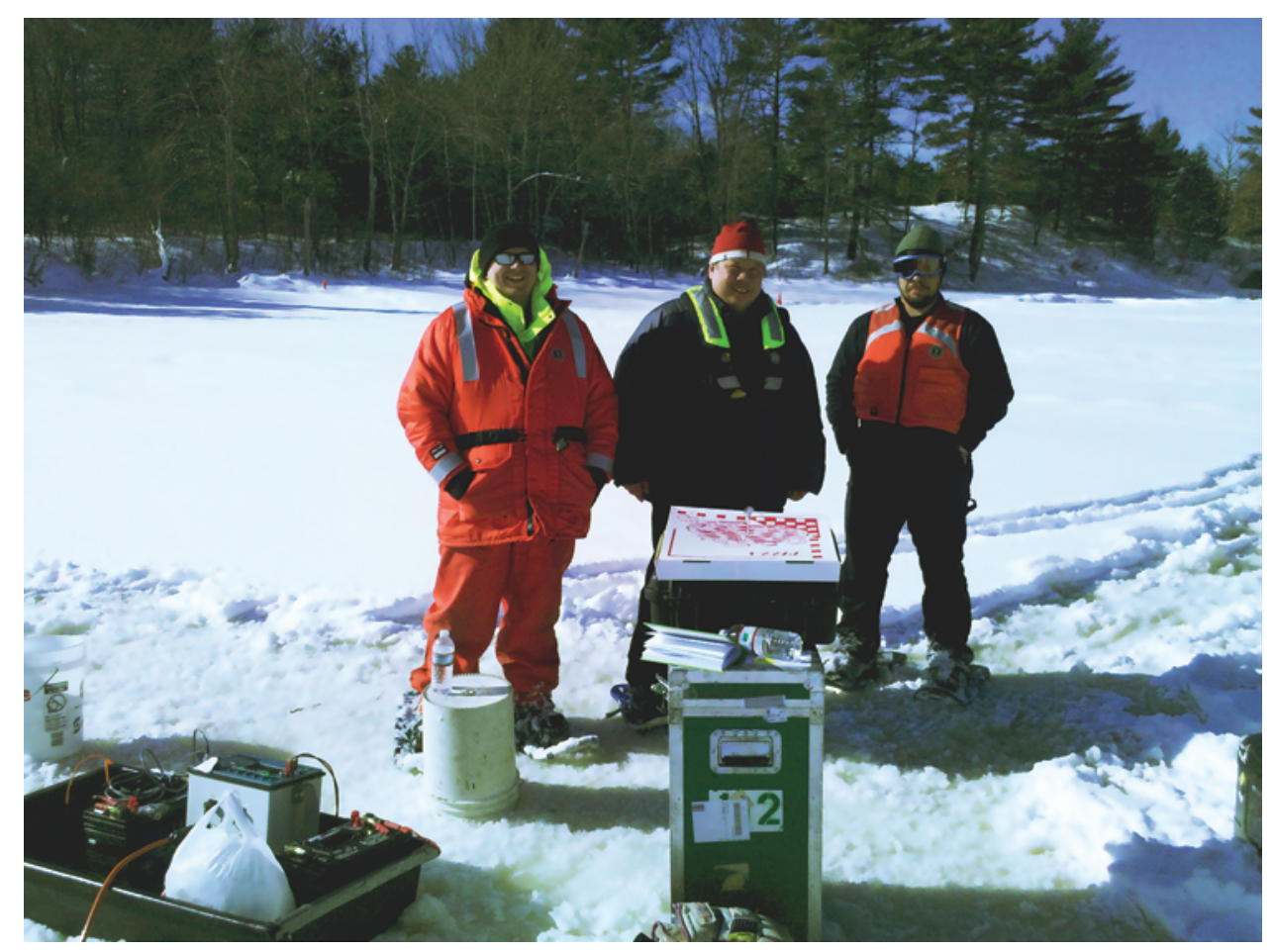

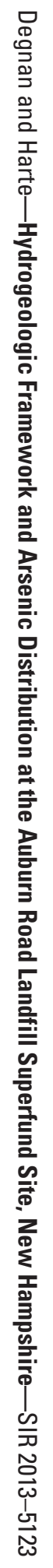

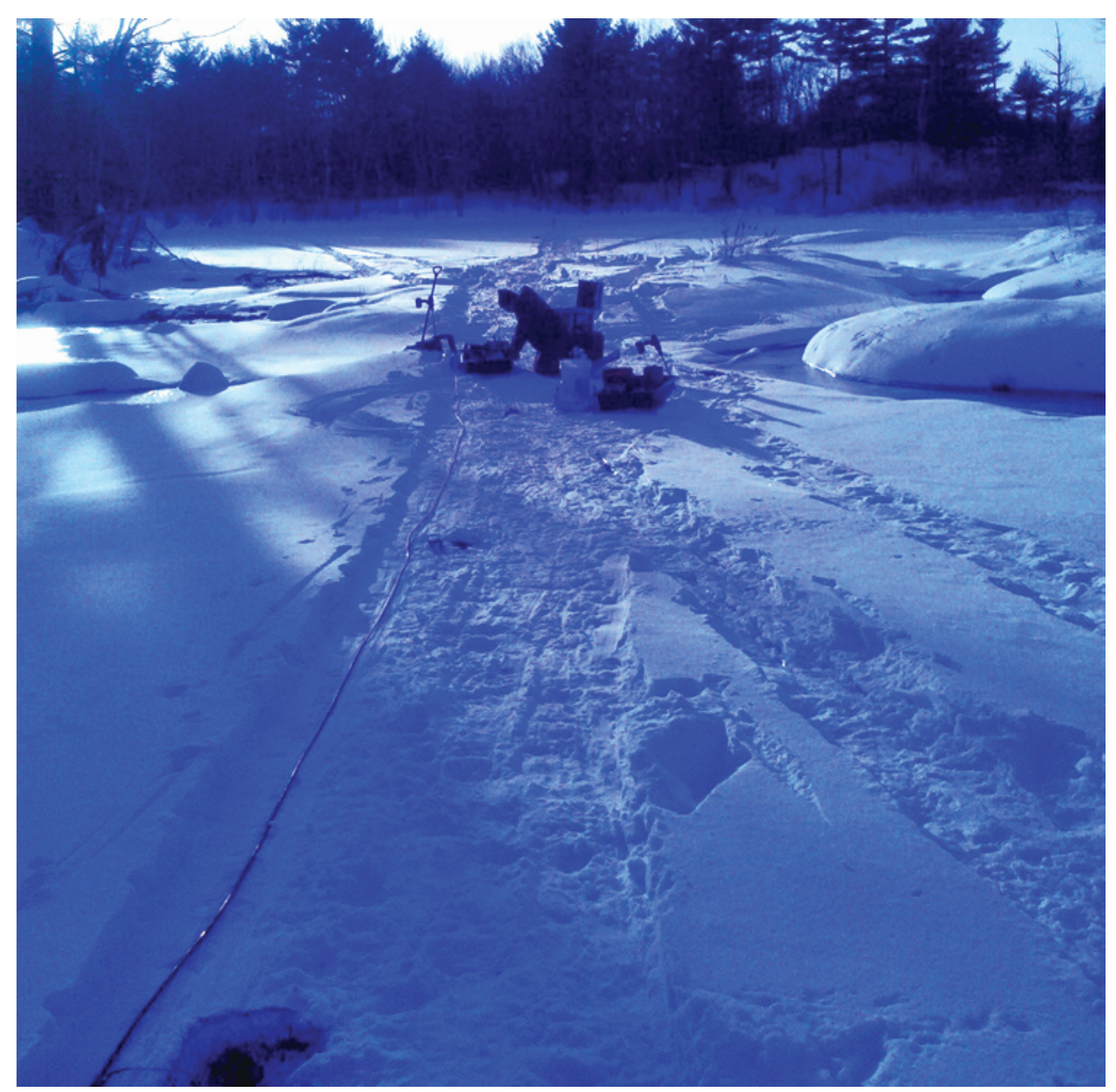

